\title{
Putting Stockholders First, Not the First-Filed Complaint
}

\section{Citation}

Leo E. Strine, Jr., Lawrence A. Hamermesh, \& Matthew C. Jennejohn, Putting Stockholders First, Not the First-Filed Complaint (Harvard John M. Olin Discussion Paper Series, No. 740, Jan. 2013).

\section{Published Version}

http://www.law.harvard.edu/programs/olin_center/papers/pdf/Strine_740.pdf

\section{Permanent link}

http://nrs.harvard.edu/urn-3:HUL.InstRepos:30064397

\section{Terms of Use}

This article was downloaded from Harvard University's DASH repository, and is made available under the terms and conditions applicable to Other Posted Material, as set forth at http:// nrs.harvard.edu/urn-3:HUL.InstRepos:dash.current.terms-of-use\#LAA

\section{Share Your Story}

The Harvard community has made this article openly available.

Please share how this access benefits you. Submit a story.

Accessibility 
ISSN 1936-5349 (print)

ISSN 1936-5357 (online)

\section{HARVARD}

JOHN M. OLIN CENTER FOR LAW, ECONOMICS, AND BUSINESS

\section{PUTTING STOCKHOLDERS FIRST, NOT THE FIRST-FILED COMPLAINT}

Leo E. Strine, Jr.

Lawrence A. Hamermesh

Matthew C. Jennejohn

Discussion Paper No. 740

$01 / 2013$

Harvard Law School

Cambridge, MA 02138

This paper can be downloaded without charge from:

The Harvard John M. Olin Discussion Paper Series:

http://www.law.harvard.edu/programs/olin_center/

The Social Science Research Network Electronic Paper Collection:

http://ssrn.com/abstract=2200499

This paper is also a discussion paper of the Harvard Law School Program on Corporate Governance 


\title{
PUTTING STOCKHOLDERS FIRST, NOT THE FIRST-FILED COMPLAINT
}

\author{
Leo E. Strine, Jr. \\ Lawrence A. Hamermesh ${ }^{\dagger}$ \\ Matthew C. Jennejohn ${ }^{\ddagger}$ \\ Putting Stockholders First, Not the First-Filed Complaint \\ January 10, 2013 Draft
}

\begin{abstract}
The prevalence of settlements in class and derivative litigation challenging mergers and acquisitions in which the only payment is to plaintiffs' attorneys suggests potential systemic dysfunction arising from the increased frequency of parallel litigation in multiple state courts. After examining possible explanations for that dysfunction, and the historical development of doctrines limiting parallel state court litigation-the doctrine of forum non conveniens and the "first-filed" doctrine-this article suggests that those doctrines should be revised to better address shareholder class and derivative litigation. Revisions to the doctrine of forum non conveniens should continue the historical trend, deemphasizing fortuitous and increasingly irrelevant geographic considerations, and should place greater emphasis on voluntary choice of law and the development of precedential guidance by the courts of the state responsible for supplying the chosen law. The "first-filed" rule should be replaced in shareholder representative litigation by meaningful consideration of affected parties’ interests and judicial efficiency.
\end{abstract}

\footnotetext{
* Chancellor, Delaware Court of Chancery; Austin Wakeman Scott Lecturer in Law, Harvard Law School; Senior Fellow, Harvard Program on Corporate Governance; Adjunct Professor of Law, University of Pennsylvania Law School; Adjunct Professor of Law, Vanderbilt University School of Law; Henry Crown Fellow, Aspen Institute.

${ }^{\dagger}$ Ruby R. Vale Professor of Corporate and Business Law, Widener University School of Law.

‡ Associate, Shearman \& Sterling, LLP, and former law clerk to Chancellor Strine.
} 


\section{Contents}

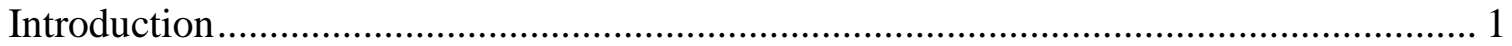

I. The Problem of Multi-Forum Litigation in Shareholder Class and Derivative Actions

II. The Doctrinal Origins of the Multi-forum Litigation Problem.................................. 26

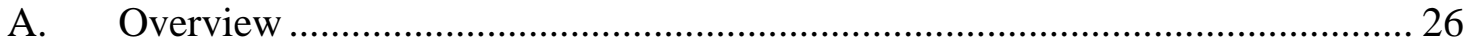

B. The Original System of Territorially Determined Jurisdiction ............................. 30

1. Pennoyer v. Neff and Its Antecedents .............................................................. 31

2. The "Vested Rights" Approach to Choice of Law Decisions ........................... 34

3. The Internal Affairs Doctrine as Jurisdictional Bar......................................... 35

4. Infrequent Parallel Litigation and the Advent of Representative Litigation... 38

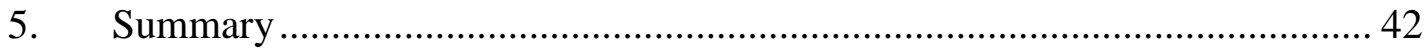

C. Extending Jurisdiction to Accommodate an Interstate Economy ...................... 43

1. The Minimum Contacts System of Personal Jurisdiction................................. 44

2. "Most Significant Relationship" Choice of Law Analysis .............................. 45

3. The Internal Affairs Doctrine Becomes Limited to a Choice of Law Rule.... 46

4. The Contemporaneous Expansion of Representative Litigation ..................... 49

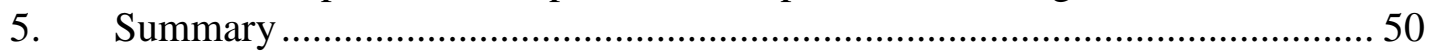

III. Forum Non Conveniens and the First-Filed Rule: Ineffective Counterbalances to

Expanding Jurisdictional Reach.......................................................................... 51

A. Forum Non Conveniens as a Basis for Declining to Exercise Jurisdiction........ 54

B. The So Called "First-Filed Rule" as an Additional Basis for Determining Priority Among Parallel Actions....................................................................... 57

IV. Diagnosing the Contemporary System's Pathologies................................................. 66

A. Pathologies of Judicial Administration ................................................................6 67

B. Non-Authoritative Adjudication Impeding Development of Precedent ............. 69

1. Why Concerns About Adjudicative Efficiency Apply to Corporate Law ...... 69

2. Forums Providing Governing Law Supply More Efficient Adjudication ...... 72

V. Rationalizing Parallel Litigation in Corporate Disputes........................................... 77

A. What Interests Merit Consideration in Resolving Competing Representative Corporate Litigation? ....................................................................................... 79

B. Proposed Doctrinal Improvements..................................................................... 87

1. Eliminate Mere Priority of Filing as a Relevant Consideration........................ 87

2. Revise The Restatement's Forum Non Conveniens Factors to Give More Weight to Parties' Choice of Law Decisions ................................................... 92

3. Reinvigorate the Restatement's Respect for Internal Affairs Doctrine .......... 95

4. The Limits of Our Recommended Doctrinal Changes ..................................... 99

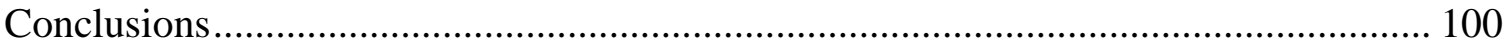


(c) 2013 Leo E. Strine, Jr., Lawrence A. Hamermesh, and Matthew C. Jennejohn. All rights reserved.

\section{Introduction $^{1}$}

Recent commentary has noted and examined the proliferation of suits brought by

stockholders in multiple forums essentially simultaneously, either derivatively on behalf

of a corporation or directly on behalf of its stockholders as a class, alleging wrongful

action or inaction by the corporation's board of directors, often regarding a transaction

such as a merger. ${ }^{2}$ In such litigation, the law's role as a facilitator of market exchange

requires that the legal system supply a single authoritative answer to the central

question — whether the directors complied with their legal and equitable duties. As we

explain below, however, the possibility of multiple answers to that question, from

multiple courts, adversely affects the interests of the stockholders whom corporate

representative litigation is supposed to benefit. And as we also explain below, outdated

\footnotetext{
${ }^{1}$ The authors gratefully acknowledge assistance from a variety of sources. Jennifer Broder, Samantha Lipton, Ian Nussbaum, and Nicholas Walter all provided invaluable research assistance and editing. Jeffrey Gorris of Bouchard Margules \& Friedlander, P.A., supplied excellent and constructive substantive criticism at every stage of drafting. The authors also thank Brian Frawley, Koji Fukumura, Steven Haas, John Hardiman, the honorable J. Travis Laster, Mark Lebovitch, Ed Micheletti, Ted Mirvis, Norm Monhait, Andrew Pincus, Paul Rowe, Bill Savitt, Jim Smith, Pam Tikellis, John Tumilty, and Jessica Zeldin for their thoughtful comments. The views expressed herein, of course, are solely those of the authors as individuals. ${ }^{2}$ See, e.g., John Armour et al., Delaware's Balancing Act, 87 IND. L.J. 1345 (2012); John Armour et al., Is Delaware Losing Its Cases?, 9 J. EMPIRICAL LEGAL STUD. (forthcoming 2012), available at http://ssrn .com/abstract=1578404; Edward B. Micheletti \& Jenness Parker, Multi-Jurisdictional Litigation: Who Caused This Problem, and Can It Be Fixed?, 37 DEL. J. CoRP. L. 1 (2012); Theodore Mirvis, Anywhere But Chancery: Ted Mirvis Sounds an Alarm and Suggests Some Solutions, 7 M\&A J. 17 (May 2007); Andrew J. Pincus, The Trial Lawyers' New Merger Tax, U.S. ChAMBER InST. FOR LEGAL Reform (Oct. 2012); Brian J.M. Quinn, Shareholder Lawsuits, Status Quo Bias, and Adoption of the Exclusive Forum Provision, 45 U.C. DAVIS L. REV. 137 (2011); Randall S. Thomas \& Robert B. Thompson, A Theory of Representative Shareholder Suits and its Application to Multi-Jurisdictional Litigation, NW. U.L. REv. (forthcoming 2012), available at http://papers.ssrn.com/sol3/papers.cfm?abstract_id=2024508; Sara Lewis, Note, Transforming the "Anywhere but Chancery" Problem into the "Nowhere but Chancery" Solution, 14 STAN. J.L. Bus. \& Fin. 199 (2008); Verity Winship, Bargaining for Exclusive State Jurisdiction, Illinois Public Law and Legal Theory Research Papers Series No. 11-21, available at http://papers.ssrn.com/ abstract=2046552 ; Matthew D. Cain \& Steven M. Davidoff, A Great Game: The Dynamics of State Competition and Litigation (Jan. 16, 2012), available at http://papers.ssrn.com/sol3/papers.cfm? abstract_id=1984758; Sean J. Griffith \& Alexandra D. Lahav, The Market for Preclusion in Merger Litigation (Oct. 1, 2012), http://papers.ssrn.com/sol3/papers.cfm?abstract_id=2155809.
} 
and inappropriate application of forum selection doctrines in multi-forum corporate litigation contributes to that effect. This article therefore examines those doctrines and urges that they be revisited and revised to better serve the interests of stockholders.

The structure of American federalism raises two basic questions when disputes cross state boundaries: first, which courts may exercise jurisdiction; and second, which state's law should apply. How our system developed to cope with those questions is well known: in the nineteenth century, questions of personal jurisdiction and choice of law were answered through doctrines that relied upon rigid geographical boundaries, which limited the exercise of jurisdiction and the choice of applicable law to a state's borders. During the first half of the twentieth century, this system changed into a more flexible arrangement where courts were permitted to exercise jurisdiction over defendants domiciled outside of their states, so long as those defendants had certain contacts with the forum. As the ability to exercise jurisdiction expanded, so did the possibility of multiforum litigation.

Amplifying the multi-forum litigation problem was the increasing use of representative actions over the same period of time, and not just in the context of corporate litigation. Often motivated by a desire to secure a role in litigation that will justify their share in potential fee awards, plaintiffs' lawyers often bring parallel actions against the same defendant in multiple jurisdictions, hoping to become the lead plaintiffs' attorney, but if not, working with the other plaintiffs' attorneys to participate in a settlement by virtue of it having filed suit in another jurisdiction that made the merger litigation difficult to consolidate or cheaper to settle than litigate. For federal litigation, the Multi District Litigation Panel emerged as a means to collect parallel actions into a 
single proceeding. ${ }^{3}$ Without a similar comprehensive mechanism at the state level, courts must rely on discretionary doctrines, such as the first filed rule and forum non conveniens, to determine which action should proceed. As we explain more fully below, those doctrines are out-dated and often unprincipled tools for addressing the modern multiforum litigation problem, and they fail to provide what commercial actors need most: a single, predictable, authoritative answer that resolves their dispute and can guide future transactions.

Our central claim is that judicial doctrines typically relied upon to sort out competing jurisdictional claims - the doctrine of forum non conveniens and the first-filed rule-developed in ways that have not adequately accounted for the nature of representative litigation or the importance to the market of the consistent development of the law governing private commercial relationships. Although the potential for multiforum litigation has existed since the beginning of our federal system, a unique combination of factors has now rendered that potential an ever-present reality in contemporary corporate practice, with resulting negative consequences for those whom representative litigation is supposed to benefit.

To remedy this problem, we advocate a doctrinal presumption that would better calibrate the connection between legal institutions and the economic relationships they are meant to support. Specifically, we argue that where lawsuits are filed

\footnotetext{
${ }^{3} 28$ U.S.C. §1407(a) (2006) ("When civil actions involving one or more common questions of fact are pending in different districts, such actions may be transferred to any district for coordinated or consolidated pretrial proceedings. Such transfers shall be made by the [U.S. Judicial Panel on Multidistrict Litigation] upon its determination that transfers for such proceedings will be for the convenience of parties and witnesses and will promote the just and efficient conduct of such actions.” See also Quinn, supra note 2, at 161 n.100, (citing John C. Heyburn, A View from the Panel: Part of the Solution, 82 TuL. L. REV. 2225, 2227-28 (2002) (discussing how the Judicial Panel on Multidistrict Litigation decides to transfer cases)); Daniel A. Richards, Note, An Analysis of the Judicial Panel on Multidistrict Litigation's Selection of Transferee District and Judge, 78 FORDHAM L. REV. 311 (2009) (presenting an empirical study of transfer orders under the Judicial Panel on Multidistrict Litigation).
} 
contemporaneously in parallel forums, the courts should give effect to the parties'

expressed choice of the law that is to govern their relationship - in the corporate context, the law of the chosen state of incorporation—by applying a rebuttable presumption that the litigation should proceed in the courts of that state. Our proposed presumption deemphasizes the role that a defendant's physical contacts with a given location plays in determining whether the exercise of jurisdiction is proper, and continues the historical trend toward emphasizing the parties’ meaningful relationship to the forum rather than geographical boundaries of incidental or unrelated activity.

The proposed presumption furthers several important values. First, giving the parties' choice of law greater importance in evaluating choice of forum promotes the consistent application of relevant doctrine, by allowing the courts that are authoritative in that law to adjudicate the case. That, in turn, promotes the growth of precedent to guide future transactions. Fostering that consistency and growth is the primary public interest implicated in corporate and contract cases, because consistency and predictability contribute to wealth creation. ${ }^{4}$ Undermining that consistency and growth denies investors and other economic actors the most legitimate and definitive source of a ruling.

\footnotetext{
${ }^{4}$ In order to allow shareholders to contract efficiently, and lower the cost at which they make their capital available, corporate law strives to be predictable. The concept of fiduciary obligations is fundamental to the corporate form and increases ambiguity in corporate law, but only insofar as the uncertainty costs arising from the application of the concept are outweighed by the added efficiency that results from giving investors confidence that their capital will be protected. See FrANK H. EASTERBROOK \& DANIEL R. FisCHEL, THE ECONOMIC STRUCTURE OF CORPORATE LAW 92 (1991) (fiduciary principles "preserve the gains resulting from the separation of management from risk bearing while limiting the ability of managers to give priority to their own interests over those of investors"); Jeffrey N. Gordon, The Mandatory Structure of Corporate Law, 89 Colum. L. REv. 1549, 1593-97 (1989) (discussing how fiduciary duties in ex post decisionmaking protect investors); Ronald J. Gilson \& Alan Schwartz, Contracting About Private Benefits of Control 36 (Yale Law \& Economics Research Paper, Nov. 29, 2012), available at http://ssrn.com/abstract=2182781 (describing the value of fiduciary duties of controlling shareholders as promoting commitment by controllers not to extract excessive private benefits of control, and asserting that "the more experienced and expert the reviewing court, the more accurate is judicial review, and the more effective, for both the controllers and the minority shareholders, is the controllers' capacity to commit”).
} 
Second, our proposed presumption enhances judicial accountability. Allowing a court to decide a case governed by another state's law deprives the highest court of the state whose law is at stake of the chance to issue an authoritative ruling. If the courts of the state whose law is at stake cannot speak, they cannot be held accountable for the law's development. In some cases, compelling circumstances relating to other parties' interests or some supervening public interest may justify that deprivation, but systematic deprivation carries with it systemic costs: it diminishes the chance for appellate courts to weave a definitive and consistent tapestry out of their state's laws, and increases the possibility of unpredictability in the law's application.

Third, giving the courts of the state of incorporation more authority will help them ensure that corporate representative litigation better serves the interests of stockholders. There is strong evidence of excess agency costs in the results of recent corporate representative litigation. ${ }^{5}$ Unless a consistent incentive system can be implemented that encourages representative litigation that benefits stockholders, the representative litigation system may on balance hurt investors more than it protects them. As federal experience shows, implementing such a system is difficult even when there is only one sovereign. When a state attempts to create a sensible corporate representative litigation system, comity and common sense suggest that its courts should be given at least presumptive primacy when a forum dispute arises, so that the state’s policies regarding the representative litigation system can be consistently enforced. This will allow those

\footnotetext{
${ }^{5}$ See, e.g., Robert M. Daines \& Olga Koumrian, Recent Developments in Shareholder Litigation Involving Mergers and Acquisitions, CORNERSTONE RESEARCH 3 (Mar. 2012), http://www.cornerstone.com/files/ Publication/2af469a2-f24a-4435-96c0-a36d24a541ae/Presentation/PublicationAttachment/876cdfd2-d105408e-aee0-a37fe880c07a/Cornerstone_Research_Shareholder_MandA_Litigation_03_2012.pdf (providing data on shareholder lawsuits); Griffith \& Lahav, supra note 2, at 32-43; Pincus, supra note 2, at 2-7; Thomas \& Thompson, supra note 2, at 17-20.
} 
courts to select the plaintiffs best able to represent stockholders with fidelity, weed out non-meritorious cases, and focus more attention on meritorious cases by setting incentives for class counsel that reward achievements for stockholders and do not encourage settlements without benefits for them. ${ }^{6}$

Fourth, our proposed presumption will tend to lighten overburdened dockets because scarce judicial resources will not as frequently be inefficiently allocated to the application of foreign states' laws. A lack of resources is a consistent refrain among American jurists. In an environment where fiscal retrenchment is commonplace, why should courts voluntarily undertake to learn and parse another state’s laws, a task that can be more efficiently accomplished by the courts of the state whose law is at stake? Rather, by concentrating on disputes governed by their own states’ law and presumptively declining to exercise jurisdiction to determine controversies governed by other states’ laws, courts will be able to resolve disputes and craft valuable precedent as efficiently as possible while also usefully refining the law of their home state.

Finally, our proposed presumption mitigates a legitimacy problem that the current system generates. There is a presumption in some cases (involving a tort victim, for example) that the plaintiff's choice of forum is legitimate and deserves some degree of deference, at least where the forum is the plaintiff's home state and the injury occurred there. ${ }^{7}$ There is no basis for such deference in the representative context, however, when

\footnotetext{
${ }^{6}$ As it stands now, forum shopping undermines a judge's ability to regulate these incentives because filing in multiple jurisdictions forces parties into premature settlements and other perverse outcomes. See infra note 54 and accompanying text.

${ }^{7}$ State courts have refused to dismiss causes of action brought by resident plaintiffs despite the availability of more convenient forums primarily due to concerns for the welfare of their residents and because those residents pay to maintain the courts. See Douglas v. N.Y., New Haven \& Hartford R.R. Co., 279 U.S. 377, 387 (1929) (upholding a New York statute that permitted courts to dismiss actions brought by non-residents but not by residents under the doctrine of forum non conveniens because "[t]here are manifest reasons for preferring residents in access to often overcrowded Courts, both in convenience and in the fact that broadly
} 
a single plaintiff purports to choose the appropriate forum for an entire class of

stockholders, the majority of whom invariably are not residents of the forum in which the suit is brought. And, that lack of legitimacy is especially acute when the named plaintiff files suit in a state in which she does not reside. In those situations, there is no reason to give any weight to the plaintiff's choice of forum - there is no “convenience” to be preserved or vulnerable interest of the plaintiff to be protected-and therefore, the suit should presumptively be heard in the courts of the state whose law was chosen by the stockholders at the outset, before litigation emerged, to govern the relationships in question.

Our proposed presumption has two principal corollaries that would refine existing conflict of laws doctrine. First, reliance on chronological precedence of filing - the socalled "first filed rule"—should be eliminated, as such, in representative shareholder actions. The first-filed rule may work tolerably well as a "tie-breaker" when a judge has to choose between two substantially similar cases filed in the same forum, and when the contending plaintiffs are similarly equipped to represent the class effectively. But, when

speaking it is they who pay for maintaining the Courts concerned”); Thomson v. Cont'l Ins. Co., 66 Cal.2d 738, 742-43 (Cal. 1967) (reversing a dismissal of a resident's breach of contract cause of action based on a "state policy that California residents ought to be able to obtain redress for grievances in California courts, which are maintained by the state for their benefit" and concerns for "the welfare of California residents"); Chapman v. S. Ry. Co., 230 S.C. 210, 215 (1956) (refusing to dismiss a case for wrongful death brought by a resident and noting that " $[\mathrm{t}] \mathrm{he}$ conclusion is inescapable that when a resident of this state sues a foreign corporation upon a transitory cause of action, where such corporation is doing business in this state, it would not be consistent with sound public policy to deny such resident access to the courts of this state for the adjudication of his rights"); Owens Corning v. Carter, 997 S.W.2d 560, 570-71 (Tex. 1999) (relying on Douglas and noting that a state statute that discriminates on the basis of residence in applying the doctrine of forum non conveniens does not violate the Privileges and Immunities Clause). This policy also reflects a concern that dismissing a resident's claim could leave a plaintiff "without a forum to litigate his claim" if other states dismiss the action under forum non conveniens too. See Comment, Forum Non Conveniens, Injunctions Against Suit and Full Faith and Credit, 29 U. CHI. L. REV. 740, 744-45 (1962); accord RESTATEMENT (SECOND) OF CONFLICT OF LAWS $\S 84 \mathrm{cmt}$. c (1971) (“[S]ince it is for the plaintiff to choose the place of suit, his choice of a forum should not be disturbed except for weighty reasons .....”). Section 84 provides that a court will not exercise jurisdiction if a forum is "seriously inconvenient" and a "more appropriate forum is available." The Restatement notes that, typically, one appropriate forum will be "the state where the occurrence took place," and another will be "the state of the plaintiff's domicil." Id. cmt. f. Very often, of course, these two forums will be the same. 
the first-filed rule is used by different judges to determine which forum should retain control of a case, the rule becomes a mechanism by which judges avoid making a considered decision on which is the proper forum for a case, and it becomes an arbitrary method of resolving the matter. By contrast, we argue that first-filed status should never be considered independently important in shareholder actions filed in multiple jurisdictions, and that staying an action on the basis of the first-filed rule is justifiable only where the second-filed action is an attempt to undo or circumvent significant progress already made in the first-filed proceeding, or presents some similarly substantial threat of inefficiency.

Second, the factors considered in the traditional forum non conveniens analysis should be given weight based on a more coherent consideration of their policy relevance. Although a state's interest in interpreting its own laws is a commonly enumerated factor in current forum non conveniens analysis, it is only one consideration among several equally-weighted concerns. Our proposed presumption would change that relationship in the context of parallel representative shareholder actions that are contemporaneously filed. Rather than simply being one factor among many, it would give greater weight to the represented shareholders' choice of law when determining whether a given forum is appropriate in a parallel litigation situation. Similarly, our proposed presumption would modify existing doctrine governing litigation involving a corporation's internal affairs by elevating the voluntary choice of governing law to primary significance, and reducing emphasis on what we submit (as discussed below) are largely irrelevant geographic considerations. In particular, it would modify § 313 of the Restatement (Second) of Conflict of Laws, which provides that "[a] court will exercise jurisdiction over an action 
involving the internal affairs of a foreign corporation unless it is an inappropriate or an inconvenient forum for the trial of the action.”8

Our analysis proceeds as follows: in Part I, we briefly review the problem of competing forums, particularly in shareholder class and derivative actions. In Parts II and III, we outline the history of the procedural and substantive rules that produced the current doctrinal structure governing multi-forum litigation. Part II recounts the expansion of personal jurisdiction doctrine and the increasing use of representative litigation, while Part III describes the development of the doctrines (forum non conveniens and the first-filed rule) that ostensibly address the potential for multi-forum litigation engendered by that expansion. Part IV inventories the pathologies that have arisen under the current doctrinal structure, and Part V outlines our suggested reforms.

\section{The Problem of Multi-Forum Litigation in Shareholder Class and Derivative Actions}

In recent years, shareholder class actions challenging mergers and acquisitions have become more prevalent, and so have instances in which litigation of this sort has been brought more or less concurrently in multiple forums. ${ }^{9}$ In 2010 and 2011, 91\% of all deals worth over $\$ 100$ million were litigated, and these deals were targeted with an

\footnotetext{
${ }^{8}$ See infra Part V.B.3.

${ }^{9}$ There is no indication that this increase is attributable to deterioration in the conduct of directors. To the contrary, and as one of us has pointed out elsewhere, many objective factors should make suits attacking corporate M\&A transactions less, not more, common now. These include: (i) improved disclosure of information required by previous judicial decisions and the SEC; (ii) the supremacy of independent directors populating most public company boards; and (iii) the decline in structural takeover defenses and the active marketing of many companies by their boards. See Leo E. Strine, Jr., Anton Philips Oration at the Anton Philips Fund Center for Company Law: The Logical, But Often Overlooked, Consequences of Corporate Governance Reform and Prior Judicial Decisions for Current Corporate Law Litigation 16-21 (Nov. 4, 2011) (discussing all three factors); see also In re Pure Res., Inc., S’holder Litig., 808 A.2d 421, 449 (Del. Ch. 2002) (discussing standards of disclosure); In re Netsmart Techs., Inc., S’holders Litig., 924 A.2d 171, 204 (Del. Ch. 2007) (same).
} 
average of 5.1 lawsuits each. ${ }^{10}$ But of these lawsuits, only 5\% resulted in a payout to shareholders. ${ }^{11} 84 \%$ of the settlements resulted only in new disclosures to shareholders. ${ }^{12}$ The lawyers, on the other hand, did well, reaping an average reported fee of $\$ 1.2$ million per settlement. ${ }^{13}$ By contrast, in 2005, only 39\% of deals worth over \$100 million were litigated. ${ }^{14}$ And, settlements that confer no financial benefit on the class have historically been far less common than they are now. In 1999 to 2000, 52\% of suits filed on behalf of shareholders produced a financial benefit for the class, and only $10 \%$ of settlements were "disclosure-only." 15 These trends coincide with an increase in the frequency of multi-forum litigation: multi-forum litigation occurred in $46.5 \%$ of litigated deals in 2010, compared to $8.6 \%$ in $2005 .^{16}$

The choice of forum in shareholder representative actions is driven almost entirely by tactical considerations of plaintiffs' counsel: it is not at all novel to point out that "the plaintiffs' lawyer typically has a greater economic stake in the litigation than the individual representative shareholder, so that litigation agency costs may ensue.”17 And in relation to multi-forum litigation, the choice of plaintiffs' counsel to file “cases in an effort to obtain a slice of the attorney fees awarded in those representative litigation cases that settle ... is a way that these lawyers attempt to derive economic rents by manipulating the

\footnotetext{
${ }^{10}$ Pincus, supra note 2, at 3 (citing Daines \& Koumrian, supra note 5).

${ }^{11}$ Daines \& Koumrian, supra note 5, at 11.

${ }^{12} \mathrm{Id}$.

${ }^{13} \mathrm{Id}$. at 12 . This figure may be distorted by very high payouts in a small number of cases. Id.

${ }^{14}$ Pincus, supra note 2, at 2; Daines \& Koumrian, supra note 5.

${ }^{15}$ Id. (citing Robert B. Thompson \& Randall S. Thomas, The New Look of Shareholder Litigation: Acquisition-Oriented Class Actions, 57 VAND. L. REV. 133 (2004)).

${ }^{16}$ Cain \& Davidoff, supra note 2, at 13-14.

17 Thomas \& Thompson, supra note 2, at 4. See also Quinn, supra note 2, at 152-54; John C. Coffee, Jr., Understanding The Plaintiff's Attorney: The Implications Of Economic Theory for Private Enforcement of Law Through Class and Derivative Actions, 86 CoLUM. L. REV. 669, 685 (1986) (describing “a serious principal-agent problem that gives the plaintiff's attorney, not the client, the real discretion as to whether to commence suit," and noting that "[t]his is the likely situation in class and derivative actions where the number of clients is large and the individual injuries small”).
} 
jurisdictional and venue rules in which litigation occurs, rather than by adding value through their litigation efforts." 18

Consistent with the view of forum choice as lawyer-driven, the increasing frequency of multi-forum shareholder representative litigation coincides with, and may be explained by, two shifting dynamics in the plaintiffs' class action bar. The first such shift stemmed from federal legislation. The Private Securities Litigation Reform Act of 1995 (PSLRA) ${ }^{19}$ was enacted to check "perceived abuses of the class-action vehicle in litigation involving nationally traded securities." ${ }^{20}$ But, the PSLRA erected barriers only to securities class actions filed in federal court, ${ }^{21}$ and the plaintiffs' bar responded by litigating such actions in state court instead..$^{22}$ In an attempt to avoid circumvention of the barriers imposed by the PSLRA, Congress enacted the Securities Litigation Uniform Standards Act of 1998 (SLUSA), which prevented plaintiffs from bringing securities actions under state law, ${ }^{23}$ and made federal securities claims brought in state court removable to federal court. ${ }^{24}$ To the extent that PSLRA and SLUSA cut down on securities class actions, plaintiffs' lawyers who had pursued multi-forum securities class actions—particularly lawyers in smaller firms lacking the resources to prosecute class actions under the new securities law regime—chose instead to bring cases invoking state corporate law claims, ${ }^{25}$ claims which SLUSA explicitly

\footnotetext{
${ }^{18}$ Thomas \& Thompson, supra note 2, at 7; see also Quinn, supra note 2, at 152 (“A plaintiff's litigation strategy based on bringing state claims outside the state of incorporation may be unnecessarily costly to shareholders who ultimately must directly or indirectly pay the costs of settlement.”).

${ }_{19}$ Pub. L. No. 104-67, 109 Stat. 737 (codified as amended in scattered sections of 15 U.S.C.).

${ }^{20}$ Merrill, Lynch, Pierce, Fenner \& Smith Inc. v. Dabit, 547 U.S. 71, 81 (2006). The House Conference Report accompanying the PSLRA found that "nuisance filings, targeting of deep-pocket defendants, vexatious discovery requests, and "manipulation by class action lawyers of the clients whom they purportedly represent' had become rampant.” Id. (citing H.R. Conf. Rep. No. 104-369, at 31-32 (1995)). ${ }^{21} 15$ U.S.C. § 77z-1(a)(1) (2006) ("The provisions of [the requirements added by PSLRA] shall apply to each private action arising under this sub-chapter that is brought as a plaintiff class action pursuant to the Federal Rules of Civil Procedure.”).

${ }^{22}$ Dabit, 547 U.S. at 82.

${ }^{23} 15$ U.S.C. §§ 77p(b), 78bb(f)(1) (2006).

${ }^{24} I d$. §§ 77p, 78bb(f).

${ }^{25}$ See Brian Cheffins et al., Delaware Corporate Litigation and the Fragmentation of the Plaintiffs' Bar, 2012 Colum. Bus. L. REV. 427, 467 ("During the 2000s there was increasingly vigorous jockeying among
} 
excluded from its purview. ${ }^{26}$ Congress further encouraged this trend in 2005, by enacting legislation (the Class Action Fairness Act, or $\mathrm{CAFA}^{27}$ ) to allow defendants to remove class actions from plaintiff-friendly state courts to federal courts. ${ }^{28}$ But CAFA, like SLUSA, exempted claims "that relate[] to the internal affairs or governance of corporations." 29 Thus, after CAFA, plaintiffs' firms seeking to file class actions in state court were even more encouraged to concentrate on state corporate cases. ${ }^{30}$

The second dynamic shift was the fragmentation of the securities class action bar. Although the PSLRA concentrated securities class actions in the hands of large plaintiffs' firms in the near term, ${ }^{31}$ the shareholder plaintiffs' class action bar became increasingly fragmented, especially after 2005, as new entrants and other events reduced the size and influence of larger and more established firms. ${ }^{32}$ In short, especially after 2005, there were more plaintiffs' class action firms with greater incentives to pursue representative shareholder litigation asserting state corporate law claims in multiple state courts.

law firms who brought securities class actions for the lead counsel role. Various firms that were pushed out of securities class actions, especially smaller firms, responded by gravitating to corporate suits.”); Howard M. Erichson, CAFA's Impact on Class Action Lawyers, 156 U. PA. L. REv. 1593, 1604 (2008) (noting that the increased expense of filing a securities class action after the PSLRA was enacted benefited the larger firms); Jennifer J. Johnson, Securities Class Actions in State Court, 80 U. CIN. L. REV. 349, 384 (2011) ("M\&A objection class actions have replaced traditional stock drop cases as the lawsuit of choice for plaintiffs' securities lawyers.”).

${ }^{26} 15$ U.S.C. $\S \S 77 b b(f)(3)(A)(i i), 77 p(d)(1)(B)$ (2006).

${ }^{27}$ Pub. L. No. 109-2, 119 Stat. 4 (codified at scattered sections of 28 U.S.C.).

${ }^{28}$ Pub. L. No. 109-2, § 2(b) (congressional statement of purpose); see Emery G. Lee \& Thomas E. Willging, The Impact of the Class Action Fairness Act on the Federal Courts: An Empirical Analysis of Filings and Removals, 156 U. PA. L. REV. 1723, 1733 (2008) (discussing CAFA's purpose). But see Stephen B.

Burbank, Aggregation on the Couch: The Strategic Uses of Ambiguity and Hypocrisy, 106 Colum. L. ReV. 1924, 1924 (2006) (calling CAFA's congressional statement of purpose "bullshit”).

${ }^{29} 28$ U.S.C. 1332(d)(9)(B) (2006).

${ }^{30}$ See S. REP. No. 109-14 (2005) ("True to the concept of federalism, [CAFA] appropriately leaves certain 'intrastate' class actions in state court: cases involving small amounts in controversy; cases with a class of 100 plaintiffs or less; cases involving plaintiffs, defendants and governing law all from the same state; cases against states and state officials; and certain securities and corporate governance cases.”).

${ }^{31}$ One firm (New York-based Milberg Weiss) between 1995 and 2003 was lead counsel or co-lead counsel in over 50\% of securities class actions. Erichson, supra note 25, at 1603-04 (2008).

${ }^{32}$ Cheffins et al., supra note 25, at 467-69 (discussing Milberg Weiss's break-up and subsequent indictment); James P. McDonald, Note, Milberg's Monopoly: Restoring Honesty and Competition to the Plaintiff's Bar, 58 DuKE L.J. 507, 532-33 (2008) (discussing Milberg Weiss's dominance of the market). 
The PSLRA may have had another unintended consequence. Perceiving that too many representative suits were brought by repeat individual plaintiffs with trivial ownership stakes and questionable motives to serve faithfully the interests of the investors they supposedly represented, Congress tried to create incentives for institutional investors to act as lead plaintiffs. ${ }^{33}$ The vision was that institutions, as well-motivated fiduciaries, would only sue when the suit had real merit and when a genuine investor would favor prosecution. ${ }^{34}$ Indeed, some envisioned that institutions would regulate the market, discouraging nuisance suits and prosecuting worthy ones more aggressively to get real benefits for the class, not just generate legal fees. ${ }^{35}$ But mainstream investment funds, such as mutual fund complexes like Vanguard and Fidelity, often do not act as plaintiffs at all. Rather, we have some reason to believe that a wide array of smaller, often public, pension funds have entered the market as frequent plaintiffs. Their behavior seems entirely consistent with that of the individual plaintiffs that concerned the authors of the PSLRA. There is cause to believe that these institutions often have few shares, but frequently attack third-party merger transactions regardless of whether any conflict of interest is involved, and propose settlements that, as we shall soon see, provide monetary benefits to the plaintiffs' lawyers, not the class. ${ }^{36}$ Less

\footnotetext{
${ }^{33}$ See Charles Silver \& Sam Dinkin, Incentivizing Institutional Investors To Serve as Lead Plaintiffs in Securities Class Fraud Class Actions, 57 DePAUL L. REV. 471, 471-75 (2008).

${ }^{34} I d$.

${ }^{35}$ This idea was suggested in Elliott J. Weiss \& John S. Beckerman, Let the Money Do the Monitoring: How Institutional Investors Can Reduce Agency Costs in Securities Class Actions, 104 Y ALE L.J. 2053 (1995).

${ }^{36}$ Our observations here are tentative, and this is a subject that is ripe for further research. But, it appears that, at least frequently, the institutional investors that sue in mergers have small ownership stakes. E.g., In re Icagen, Inc. S'holder Litig., C.A. No. 6692-CS (Del. Ch. Apr. 5, 2012) (disclosure-only claim in a merger worth $\$ 56$ million, where co-lead plaintiffs were an individual with 18,000 shares worth $\$ 108,000$, a fund with 7,500 shares worth \$45,000, and an individual with 862 shares worth \$5,172); In re Burlington N. Santa Fe S'holders Litig., C.A. No. 5043-VCL (Del. Ch. Oct. 28, 2010) (disclosure-only claim in a merger valued at $\$ 44$ billion with one co-lead counsel representing municipal pension fund with stake of 3,643 shares, worth \$364,300); In re Sepracor, Inc. S’holders Litig., C.A. No. 4871-VCS (Del. Ch. May 21, 2010) (disclosure-only claim in a $\$ 2.6$ billion dollar merger where one co-lead plaintiff was a union pension fund with 3,515 shares, worth $\$ 80,000$, and the other co-lead plaintiff an individual with 100 shares, worth \$23,000); IBEW Local Union 98 v. Noven Pharms. Inc., C.A. No. 4732-CC (Del. Ch. Dec. 30 , 2009) (disclosure-only claim in a \$428 million merger with three union pension funds and one
} 
debatable than their motivation is the reality that the proliferation of small institutions acting as repeat plaintiffs has contributed to the number of challenges filed to every announced transaction, the number of law firms in the market, and the incentives to use forum-shopping to jockey for a seat at the table. This is not a phenomenon limited to Delaware corporations. Corporations incorporated in many states now appear to suffer material costs in litigation over multiple jurisdictions, which results in payment of attorneys' fees but no benefit for shareholders. ${ }^{37}$

individual acting as plaintiffs; the greatest stake was of 9,300 shares, worth approximately \$150,000); In re Interwoven, Inc. S’holders Litig., C.A. No. 4362-VCL (Del. Ch. Feb. 20, 2009) (appointing as co-lead plaintiffs a pension fund with a stake of $\$ 1.6$ million, and two individuals with a combined stake of $\$ 11,200$; not appointing as a lead plaintiff a pension fund that had a stake only worth $\$ 9,000$; and later approving a disclosure-only claim, in a $\$ 775$ million deal). The attorneys were paid in all of these suits, with the highest fee award being $\$ 550,000$. In none of these cases did the transaction the plaintiffs challenged get altered; each was approved by the stockholders at the same level of consideration as when the plaintiffs filed suit.

Furthermore, the speed with which lawsuits are filed is another sign that large institutional investors are not regulating the market, unlike in the idealized vision of securities litigation under the PSLRA. See supra notes 33-35 and accompanying text. The rapidity with which many institutional investors bring suits suggests that, at many institutions, no actual time is spent deciding whether to sue, and that institutions have arrangements with certain counsel authorizing those counsel to sue within twenty-four hours of an announced premium-paying transaction. See William B. Rubenstein, What We Now Know About How Lead Plaintiffs Select Lead Counsel (and Hence Who Gets Attorneys Fees!) in Securities Cases, 3 Class ACTION ATT'y FEE DIG. 219, 219-20 (2009) (“'S]ome plaintiffs firms have entered into arrangements whereby they monitor the funds' investments for irregularities and suggest possible grounds for litigation.”). The ownership stakes of many of the institutions are so low that it would arguably be an act of fiduciary impropriety for the institution to spend any material time on a lawsuit, because any use of staff time would be disproportional to the thousands of dollars the institution has invested. All of these realities are symptoms of a serious agency problem.

${ }^{37}$ For example, in 2010, Endo Pharmaceutical agreed to purchase Penwest Pharmaceuticals, a Washington corporation. The merger was attacked immediately in state and federal court in Washington and New York states. Less than a month after the first lawsuit was filed, Penwest decided to enter into a global settlement to ensure that the merger would close, even though it stated in its SEC filings that "each of the [five] lawsuits is entirely without merit." In return for the global settlement, Penwest provided additional disclosures and agreed not to oppose the plaintiffs' application for attorneys' fees, "not to exceed \$450,000." Penwest Pharmaceuticals Co., Schedule 14A (Amendment No. 1 to the Proxy Statement), at 10 (Oct. 1, 2010). As another example, in 2009, Pulte Homes. agreed to buy Centex, a Nevada corporation. Centex shareholders sued in both Nevada and Texas. The suits were settled for \$1.1 million in attorney's fees, but with no recovery for the class. Rocker v. Centex Corp., 377 S.W.3d 907 (Tex. Ct. App. 2012), vacated and remanded by agreement of the parties. And as yet a further example, in February 2011, Ventas, a REIT, agreed to purchase Nationwide Health Properties, a Maryland corporation headquartered in California. Seven suits were filed against Nationwide within a month, in both California and Maryland. They were eventually consolidated and settled: Ventas made supplemental disclosures, but there was no recovery for the class. See Ventas, Inc., Quarterly Report (Form 10-Q) 27 (Nov. 7, 2011). These three brief examples confirm that all corporations that are involved in mergers, no matter where they are chartered, are at risk of suffering the costs of burdensome multiforum litigation that does not deliver benefits for shareholders. 
Despite this, Professors Thomas and Thompson tentatively conclude that multi-forum litigation does not "appear to generate much in the way of additional costs.”38 They do caution that " $[\mathrm{t}]$ here is more work to be done to empirically document what are the extra costs associated with multiple lawsuits being filed in different courts for each transaction and when such additional costs are material.” ${ }^{39}$ We think otherwise: multi-forum litigation does engender costs, and those costs are non-trivial. ${ }^{40}$ Most notably, growth in the frequency of deal litigation does not seem to be matched by growth in recoveries for those whose interests are to be represented in such litigation. To the contrary, the recent evidence described above demonstrates the predominance of deal litigation settlements involving payment of attorney’s fees to plaintiffs' counsel, but no payment to class members. ${ }^{41}$ We acknowledge that in some circumstances supplemental disclosure or other non-monetary consideration can justify a settlement in which plaintiffs' counsel earns a fee, ${ }^{42}$ but the absence of any monetary

${ }^{38}$ Thomas \& Thompson, supra note 2, at 64 .

${ }^{39}$ Id. n.252.

${ }^{40}$ A very distinguished judge who served for many years on the North Carolina Business Court seems to share our concerns:

The fees paid to counsel and plaintiff are what this Court has come to regard as "stinky fees." They just smell bad and have no economic justification. We have come to the point in this country that whenever a merger is announced, some lawyer with a client holding a small number of shares rushes to file a lawsuit containing class action allegations. After minimal discovery and review by an "expert," plaintiff requests that "additional information" be disclosed and agrees to go away with settlement in handhaving done absolutely nothing for the class.

For their part, defense lawyers, investment bankers, and the companies are willing to pay these fees to get the deal done, regardless of the merits....

In the future, judges should decline to approve any settlement that does not benefit shareholders in a material way. Stinky fee suits may actually discourage other legitimate and serious claims, thus doing further damage to our system.

Ward v. Lance, Inc., C.A. No. 10-CVS-16553, at 1-2 (N.C. Super. Ct. Feb. 28, 2011) (ORDER). We believe that the growth in settlements of this nature is attributable in material measure to the perverse incentives caused by forum shopping, which disables the judges of the state of incorporation from fixing the incentive system in the manner that Judge Tennille suggests and, as importantly, increases the costs and uncertainty of litigation to defendants in a manner that makes "stinky" settlements more rational than moving to dismiss or otherwise fighting a meritless case.

${ }^{41}$ See supra notes 9-16 and accompanying text.

${ }^{42}$ E.g., Tandycrafts, Inc. v. Initio Partners, 562 A.2d 1162, 1165 (Del. 1989) (“[A corporate benefit justifying a fee award] need not be measurable in economic terms. Changes in corporate policy or, as here, a heightened level of corporate disclosure, if attributable to the filing of a meritorious suit, may justify an award of counsel fees.”); In re Sauer-Danfoss Inc. S’holders Litig., 2011 WL 2519210, at *18, 21, Appx. 
consideration in $84 \%$ of deal litigation settlements, together with the increase in the volume of such litigation, suggests that less salutary considerations may be at work, and that there is a systemic failure endangering the ability of representative shareholder litigation to produce net benefits to investors. ${ }^{43}$

Perhaps, because these statistics confirm what many practitioners and judges already knew, we have dulled ourselves to clear evidence of a problem. So we underscore the lesson conveyed by the data. In these cases, plaintiffs, claiming to be representatives of all stockholders, settled cases attacking the fairness of a proposed transaction. Yet $84 \%$ of the time in the deals attacked in 2011, the stockholders got the same consideration the plaintiffs challenged as unfair, with only some additional disclosures of information. ${ }^{44}$ Another $11 \%$ of the time, the stockholders got almost the same deal, with some "irrelevant and immaterial" terms changed. ${ }^{45}$ Only $5 \%$ of the time did the stockholders receive an increased payout. But $100 \%$ of the time, the plaintiffs' lawyers got fees. Would any bona fide stockholder find this useful? By analogy, it is difficult to imagine that it would be acceptable for $84 \%$ of medical malpractice suits to be settled with plaintiffs’ lawyers succeeding in obtaining only additional information about what the physician did wrong, but not getting a monetary award for their clients and still getting a fee for their victory. ${ }^{46}$ Nevertheless,

A-C (Del. Ch. Apr. 29, 2011) (comparing “meaningful” and "exceptional” disclosures, which merit substantial fees, with disclosures "of questionable quality”); 1-9 DONALD J. WOLFE, JR. \& MiCHAEL A. PitTenger, Corporate \& COMmercial Practice in the Delaware Court OF Chancery § 9.05[C] (updated 2012) (reviewing examples of non-monetary benefits giving rise to fee awards).

${ }^{43}$ See, e.g., Thompson \& Thomas, supra note 15, at 152-55 (identifying "common indicia of litigation agency costs" to include suits being settled "quickly for small amounts," and "multiple lawsuits being filed against the company for the same alleged wrongdoing").

${ }^{44}$ Pincus, supra note 2 (citing Cain \& Davidoff, supra note 2).

${ }^{45} I d$.

${ }^{46}$ This analogy may not be apt where supplemental disclosure is genuinely material to further stockholder deliberation and voting. See Sauer-Danfoss, 2011 WL 2519210, Appx. C (identifying fee awards based on "particularly significant or exceptional disclosures"). But in too many cases in which disclosure is "minimally beneficial," the analogy is sound. Id. at 19. As noted, the rise of supermajorities of independent directors on boards, the decline in structural takeover defenses, and the improvement in disclosures all suggest that litigation over M\&A transactions should have become rarer, not more frequent. See Strine, 
this continues to happen in the corporate law context, and what happens is that the cost of capital for American corporations goes up, lawyers get paid, and stockholders suffer drag.

And indeed, there are a number of ways in which the prevalence of multi-forum litigation and the inability or unwillingness of courts to limit the effects of such litigation can exacerbate inefficiencies and "race to the bottom"-type behavior in the handling of representative corporate litigation. Such effects, in turn, predictably increase the deadweight costs of such litigation. We outline below several illustrative scenarios in which these effects might plausibly occur, and these scenarios are not at all hypothetical—-they describe circumstances we have observed, and experienced practitioners in the deal litigation field confirm that they reflect situations they have encountered: ${ }^{47}$

- $\quad$ Unnecessary expedited proceedings in weak cases. Shareholder class actions are brought in multiple forums (including the state of incorporation), asserting a claim of breach of fiduciary duty based on an alleged failure to satisfy fiduciary obligations associated with the sale of the company by a board with a supermajority of independent directors; the challenged transaction is at arms' length; deal protection devices are standard, and no other bidder has surfaced; and claims of failure to disclose material information are strained at best. Based on their familiarity with cases of this sort, the defendants in the case in the court in the state of incorporation would be inclined to oppose plaintiffs' request for expedited proceedings, and the court would be inclined to deny that request. Because of the pendency of essentially identical proceedings in the other forum, however, and in the absence of reasonable

supra note 9, at 16-22. Another reality underscores this point: in almost every disclosure-only case, the disclosures the plaintiffs obtain do not change the result, and the transaction the plaintiffs challenged is supported by the electorate (including the plaintiffs) in unaltered form.

${ }^{47}$ We have consulted a wide range of experienced practitioners and corporate law scholars and considered a wide variety of actual corporate representative cases. Those consultations and that evidence convince us that the general scenarios that we outline here are in fact common results of filing cases involving a single corporate transaction or decision in multiple forums. 
certainty that the court in that other forum would abstain from exercising jurisdiction, the defendants have little practical choice but to agree to and actively support expedition. For example, in Stourbridge Investments $L L C$ v. Bersoff, the court denied a motion to expedite proceedings, supported by defendants, where defendants’ counsel had candidly explained, "the Virginia action certainly changed the way we viewed the Delaware action. ... . We weren’t confident we could successfully oppose expedition in both jurisdictions, so we agreed to not oppose in Delaware and have moved to stay in Virginia based upon the pendency of the Delaware case.” 48 Denials of motions to expedite in non-meritorious cases have not stopped plaintiffs' lawyers from seeking out other jurisdictions to bring their claims, ${ }^{49}$ and, likewise, do not

\footnotetext{
${ }^{48}$ Tr. of Oral Arg., Stourbridge Invs. LLC v. Bersoff, C.A. No. 7300-VCL, at *4-5 (Del. Ch. Mar. 13, 2012).

${ }^{49}$ In a striking example from October 2011, a distinguished plaintiffs' firm litigated the Medco/Express Scripts merger in federal court in New Jersey, after seeking expedited treatment in that jurisdiction. A second distinguished plaintiffs' firm wanted the case to go ahead in Delaware, where the companies were incorporated. See Tr. of Scheduling Conf., In re Medco Health Solutions, Inc., S’holders Litig., C.A. No. 6720-CS (consol.) (Oct. 21, 2011). Ten days later, there was a role reversal. In litigation relating to the El Paso/Kinder Morgan merger (again two Delaware corporations), the first firm now sought to litigate the case in Delaware, whereas the second firm sought to litigate outside Delaware, in Texas. See Tr. of Status Conf., Kahn v. Foshee, C.A. No. 6949-CS (Oct. 31, 2011).

Many commentators suspect that the Delaware courts' expertise in identifying weak cases, and weeding them out quickly, has contributed in part to the current dysfunctional dynamic by encouraging plaintiffs' lawyers to bring weak suits in which the only real goal is a quick settlement for fees elsewhere. See Micheletti \& Parker, supra note 2, at 6; Mirvis, supra note 2, at 17. Moreover, there are other factors that affect where plaintiffs file that these judicial tools cannot address, such as jurisdictions that offer discovery on motions to dismiss. Armour et al., Delaware's Balancing Act, supra note 2, at 1377-80. So to the extent that such multi-forum litigation continues to occur, simply cutting fees, denying motions to expedite, and granting motions to dismiss claims are likely to have little impact on the current problems. See John C. Coffee, Foreword: The Delaware Court of Chancery: Change, Continuity—and Competition, 2012 Colum. Bus. L. REV. 387, 390 ("Discouraging litigation in Delaware (even non-meritorious litigation) only increases the migration of cases out of Delaware.”). The data on attorneys' fee awards in stockholder representative litigation show that it is not the case that Delaware judges are reluctant to award fees in meritorious cases. In the nine years since the Delaware Court of Chancery began a system of electronic filing, the court has awarded $\$ 780$ million in attorneys' fees and expenses. Even setting aside the $\$ 300$ million fee award in the Southern Peru case, which was made in response to a recovery to the class of shareholders of over $\$ 2$ billion, the Court of Chancery has awarded \$475 million in fees and expenses over the past nine years. Fee awards of over $\$ 5$ million were issued in 27 cases in that period, and awards of over $\$ 10$ million on 11 occasions. Thus, the inability to get a substantial fee from a Delaware court for generating a substantive benefit for stockholders is not a plausible explanation. See Register in Chancery Court of Delaware, Data on Fee and Expense Awards (updated Nov. 20, 2012); see also In re S. Peru Copper Corp. S'holder Derivative Litig., 52 A.3d 761 (Del. Ch. 2011), aff'd, Ams. Min. Corp. v. Theriault, 51 A.3d 1213 (Del. 2012).
} 
necessarily induce other courts to follow suit. ${ }^{50}$ Rather, filings by multiple plaintiffs' law firms in multiple forums can be viewed as cooperative, as well as competitive, because the resulting additional defense costs and uncertainties about which court will hear the case, and how it will decide it, increase the pressure on defendants interested in global resolution of litigation to pay larger overall attorneys’ fees than might be paid if litigation were confined to a single forum. The issue is not trivial because significant costs of discovery and disruption result from the choice to pursue expedited motions in parallel litigation, in the form of litigation expense that would otherwise be avoided. In a world in which settlements of these cases involve only payment of attorney's fees and not additional payments to stockholders, the corporations involved in the merger, and therefore their investors, bear those costs. Thus, those costs contribute to an increase in the cost of capital, and a net negative societal impact.

- $\quad$ Quick Settlements That Monetarily Benefit Only Plaintiffs’ Lawyers, Not

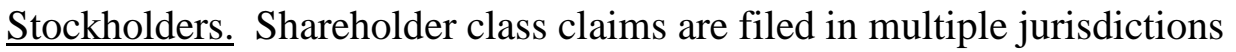
asserting claims for breach of fiduciary, typically invoking the duties owed by directors under cases like Lynch $^{51}$ and Revlon. ${ }^{52}$ The defendants and their counsel have no certainty that every forum will stay or dismiss the case in favor of the courts of the state of incorporation. The defendants and their counsel also have

\footnotetext{
${ }^{50}$ We do not claim that courts outside the state of incorporation invariably refuse to dismiss deal challenges, or always grant motions for expedited proceedings in such cases. See, e.g., In re Blackboard, Inc. S’holder Litig., 2011 CA 005465 B (D.C. Super. May 23, 2012) (dismissing class action after having rejected a motion to expedite). We also acknowledge that judges often defer to the jurisdiction whose laws are at stake. See infra notes 179 and 231. But some judges do not, a circumstance that creates incentives for forum shopping..

${ }^{51}$ Kahn v. Lynch Commc’n Sys., Inc., 638 A.2d 1110 (Del. 1994) (requiring the application of the entire fairness doctrine to a merger with a controlling stockholder).

${ }^{52}$ Revlon, Inc. v. MacAndrews \& Forbes Holdings, Inc., 506 A.2d 173 (Del. 1986) (requiring the directors to undertake reasonable efforts to secure the highest price when selling the company).
} 
limited familiarity with how the courts of the other states handle corporate law matters, because those courts rarely do. Faced with this situation and the certainty of litigation costs and some degree of deal risk simply because of this inefficient and uncertain litigation context, the defendants have a rational incentive to settle the case early and cheaply if that will enable the deal to be completed as proposed and end the litigation. ${ }^{53}$ Indeed, if the defendants believe that the transaction is good for stockholders, as they should if they are directors recommending the transaction, then settling cases that are an obstacle to the transaction in a costeffective way is a proper fiduciary act. The defendants thus are willing to settle the case by disclosing more information about the transaction and accepting the cost of paying attorneys' fees to the plaintiffs' lawyers, especially if that can be done in a way that results in all plaintiffs' attorneys in all forums agreeing to stand down.

This dynamic leads to two worrying possibilities. The first, which is exemplified by the data on settlements where only the attorneys get a monetary benefit, is that meritless cases are being rewarded and that investors and corporations are suffering an unjustifiable increase in the cost of capital as a result of agency cost factors exacerbated by forum shopping. Usually, the plaintiffs' attorneys file parallel actions in multiple forums challenging a pending arm's length merger on the theory that the directors have failed to achieve the highest available value. A court familiar with the applicable law might appreciate that the

\footnotetext{
${ }^{53}$ E.g., In re Xoma Corp. Sec. Litig., 1992 U.S. Dist. LEXIS 10502, *3 (N.D. Cal. July 10, 1992) (“The law favors settlement of cases and quieting of litigation, particularly in complex class actions and derivative litigation.”); Rome v. Archer, 197 A.2d 49, 53 (Del. 1964) (noting, in context of derivative suit, that law "favors the voluntary settlement of contested issues"); accord Denver Area Meat Cutters v. Clayton, 209 S.W.3d 584, 590 (Tenn. App. 2006) (same).
} 
case is quite weak. In the interest of avoiding litigation uncertainty, however, and given the pendency of multiple suits, the parties agree to a settlement in which no additional consideration is to be provided in the transaction, but that some additional disclosure would be provided, and that defendants would not oppose a fee application by plaintiffs’ counsel up to a material but limited amount, particularly if the plaintiffs' lawyer negotiating the settlement can get all plaintiffs in all cases on board to share the fees. Acting independently, a knowledgeable court might reject the settlement as illusory: because the plaintiffs have advanced claims that have little to no value—-such as attacks on third-party merger transactions proceeded by a lengthy and open sales process - the additional disclosure supports the release, and it would seem to punish the defendants to force them to defend litigation of trifling utility in multiple forums by denying approval. $^{54}$

The second, however, is that in the wave of such repeated meritless suits, some good suits get missed and valuable claims are released for inadequate consideration. Better plaintiffs’ lawyers may shy away from multi-forum "herd” cases where their more diligent and skilled approach might have generated information supporting more substantial relief than repeat filers happy with a quick disclosure only settlement. More likely, a more diligent lawyer who sued might feel pressure to join the herd, when other plaintiffs' lawyers are willing to settle for additional disclosures, fearing that the settlement might proceed and a

\footnotetext{
${ }^{54}$ See, e.g., In re Topps Co. S’holder Litig., 924 A.2d 951, 961 (Del. Ch. 2007) (“[S]tockholders want to have unmeritorious cases dismissed without rewarding plaintiffs' lawyers for the simple fact that they filed a lawsuit."); id. n.38 (“Absent the rational sifting out of non-meritorious cases, stockholders suffer as the costs of litigation exact an undue toll on the procession of transactions valuable to stockholders and cause a harmful diminution in wealth-generating risk-taking by directors.”).
} 
release entered, without the lawyer's participation in the resulting fee

award. Both possibilities are made more likely realities as a result of the perverse incentives created by forum disputes. ${ }^{55}$

- $\quad$ Hastily prepared derivative complaints. With derivative litigation potentially brought in multiple forums, plaintiffs' counsel must consider whether to engage in extended investigation (including use of statutory rights to inspect corporate documents ${ }^{56}$ ) before filing a complaint, or to file as soon as possible, on the basis of sparse publicly available information. Plaintiff's counsel who opts for investigation and deliberation may find herself the "loser" under rules of jurisdictional priority that favor the firstfiled lawsuit. ${ }^{57}$ That counsel faces at least some risk that a poorly drafted, factually weak complaint in another forum may result in dismissal under rules governing presuit demand on the board of directors, and that such a dismissal would be invoked against his more fully researched complaint, when it is eventually filed. ${ }^{58}$ A rational

\footnotetext{
${ }^{55}$ There is a third, also suboptimal, possibility: where a shareholder claim is unlikely to prevail in the courts of the state of incorporation, plaintiffs' counsel may be drawn to the courts of a different state in the hope of achieving a better result in a court less familiar with and less likely to correctly apply governing law. Viewed ad hoc, this possibility might be seen as beneficial to shareholders; as a systemic matter, however, it is suboptimal for investors as a whole because it defeats the legitimate expectations of all parties (both management and stockholders) with interests at stake. It is also an intrusion, inconsistent with generally accepted conflict of laws principles (the internal affairs doctrine), on the authority of the state of incorporation to define the relationships and duties among management and stockholders. See infra notes 222-227 and related text.

${ }^{56}$ See, e.g., Brehm v. Eisner, 746 A.2d 244, 262 n.57 (Del. 2000) ("Plaintiffs may well have the 'tools at hand' to develop the necessary facts for pleading purposes. For example, plaintiffs may seek relevant books and records of the corporation under Section 220 of the Delaware General Corporation Law, if they can ultimately bear the burden of showing a proper purpose and make specific and discrete identification, with rifled precision, of the documents sought."); accord In re Quintiles Transnat'l Corp. S'holders Litig., 2003 NCBC 11, ๆๆ 21-23 (N.C.B.C.); Kanter v. Barella, 388 F. Supp. 2d 474, 481 (D.N.J. 2005).

${ }^{57}$ See infra Section III.B.

${ }^{58}$ Courts have given preclusive effect to the dismissal of suits with poorly researched complaints despite the later filing of well-researched complaints. See In re Sonus Networks, Inc., 499 F.3d 47, 53, 60 (1st Cir. 2007) (affirming trial court's dismissal of suit on the basis of issue preclusion despite additional facts not pled in first action and holding that "a party should be held to account not only for what he actually pleaded, but for what he could have pleaded in the earlier suit”); Henik ex rel. LaBranche \& Co. v. LaBranche, 433 F. Supp.2d 372, 380-82 (S.D.N.Y. 2006) (giving preclusive effect to a dismissal under Federal Rule of Civil Procedure 23.1 based on failure adequately to plead demand futility); LeBoyer v. Greenspan, 2007 WL 4287646, at *2 (C.D. Cal. June 13, 2007) (precluding plaintiff from relitigating different claims
} 
response (or really anticipation) by a plaintiff's lawyer in these circumstances is to forego careful investigation and file a complaint as quickly as possible. The foreseeable result is the prevalence of complaints that are most likely susceptible to dismissal, and, in turn, the impairment of potentially more viable derivative suits and the diminution of the benefits to investors of that form of litigation. Another foreseeable result is the imposition on corporate defendants of the costs of addressing and dismissing inadequately supported derivative complaints, costs that are ultimately borne by investors. $^{59}$

- Improvident, accelerated lead counsel determinations or even class certification. In parallel shareholder class actions, competing plaintiffs’ counsel have a powerful incentive to establish priority for their respective selected forums. More particularly, they are strongly motivated to force as quickly as possible the decision on which counsel should be designated as lead counsel, who should be the lead plaintiff whether to certify a class, and how the class should be defined. Ideally, such matters

regarding different time periods); In re Bed Bath \& Beyond Derivative Litig., 2007 WL 4165389, at *6-7 (D.N.J. Nov. 19, 2007) (holding that the "[f]ailure of the [earlier] plaintiff to raise the additional claims and issues that the Plaintiff has raised here does not justify relitigation”); Arduini ex rel. Int'l Game Tech. v. Hart, 2012 WL 893874, at*3 (D. Nev. Mar. 14, 2012) (noting that the“[p]laintiff's arguments that he has allegations specific to the demand futility issue that are different from the allegations brought up in [the underlying proceeding do not] preclude our use of issue preclusion"); In re Career Educ. Corp. Derivative Litig., 2007 WL 2875203 (Del. Ch. Sept. 28, 2007) (appeal pending) (holding that doctrine of issue preclusion barred plaintiffs from relitigating issues contained in a separate derivative complaint that was dismissed with prejudice). This is precisely the situation addressed in Louisiana Municipal Police Employees' Retirement System v. Pyott, 46 A.3d 313, 324-51 (Del. Ch. 2012). The ruling in that case, however, if widely followed, might ameliorate the concerns expressed here about this scenario: the opinion adopted a presumption that the self-selected shareholder representative who commences a "fast-filed" derivative action is not an adequate representative and, therefore, a dismissal of her hastily filed complaint will not preclude prosecution of a later-filed, more forceful derivative complaint in another forum. Id.

${ }^{59}$ Pyott, 46 A.3d at 338 ("When plaintiffs sue derivatively to recover damages from directors and senior officers for harm suffered by the corporation, the hastily filed complaints have little chance of surviving a Rule 23.1 motion, yet the defendant fiduciaries must respond, and the corporation must underwrite the costs of defense, either directly through indemnification and advancement or indirectly through insurance.”). 
would be determined promptly, to be sure, ${ }^{60}$ but a plaintiff's counsel, a court, and defendants interested in establishing priority for their preferred jurisdiction will want to press for resolution of these procedural matters, rather than linger on any difficult questions associated with identifying the most suitable class or derivative representative. Costs of poor decision making on these matters stem directly from undue potential for inter-forum competition, and are borne by investors, directly or indirectly.

The common thread in each of these scenarios is that uncertainty about choice of forum incentivizes participants in the system—plaintiffs' lawyers, and defendants and their counsel—to seek or accept these outcomes. One might look to judges to police inefficient litigation, but there are several possible circumstances that, operating separately or in tandem, might limit the judges' effectiveness in this regard. We feel obligated to touch on this delicate subject. At the basest level, some might suggest that a judge may be motivated by campaign contributions from plaintiffs' counsel, ${ }^{61}$ or by loyalty to plaintiff's counsel who is a former clerk or personal friend. We would expect such motivations to be rare, however. More likely is the possibility that a judge may be broadly loyal to her institutional settingthe bar in which she practiced and which she continues to inhabit-and may wish to avoid disappointment and resentment that might arise from dismissing litigation that is remunerative to that bar. Another possibility is that a judge may find class and derivative litigation intellectually and reputationally more rewarding than a more standard diet of

\footnotetext{
${ }^{60}$ E.g., FED. R. CIV. P. 23(c)(1)(A) (“At an early practicable time after a person sues or is sued as a class representative, the court must determine by order whether to certify the action as a class action.”); Bertrand v. Maram, 495 F.3d 452, 455 (7th Cir. 2007) (criticizing failure to rule on class certification motion before resolution of the merits); Prezant v. De Angelis, 636 A.2d 915, 921 (Del. 1994) (stating that Chancery Court Rule 23(c)(1) "appears to contemplate a determination of whether an action is properly maintainable as a class action at an early stage of the litigation”); Howe v. Microsoft Corp., 656 N.W.2d 285, 291-93 (N.D. 2003) (emphasizing importance of early resolution of class certification). ${ }^{61}$ See Caperton v. A.T. Massey Coal Co., 556 U.S. 868, 883 (2009) (invoking “objective rules” to determine whether a judge's recusal was constitutionally required).
} 
routine civil or criminal cases. Ultimately, however, settlements of non-meritorious claims disserve investors, and our nation as a whole, by raising the cost of capital. On balance, the system favors plaintiffs' counsel, by conferring additional fee awards which might not otherwise be justified. The system may also favor individual defendants (primarily corporate directors), who may get a windfall benefit from settlements because the incentive system we have described means that some strong cases may settle too cheaply, with claims extinguished at no cost to the fiduciaries who have acted questionably. ${ }^{62}$

Noting the competition or cooperation among plaintiffs' lawyers filing class actions, Professors Griffith and Lahav have recently described the system of bringing and settling corporate class actions as a market process. ${ }^{63}$ Griffith and Lahav argue that plaintiffs, by filing in multiple states (where complaints cannot be consolidated), create a market of sellers who all have the power to "sell" a settlement (or a judgment) to the defendant firm. ${ }^{64}$ Because a settlement in one state has preclusive effect on all parallel suits, defendants will seek to buy a settlement, and hence certainty that whatever transaction is being litigated can proceed. ${ }^{65}$ Griffith and Lahav believe that there are positive effects associated with the multi-jurisdictional filings, such as the strategic outsourcing of weak cases from the state of incorporation, and that problems with the current system can be fixed by greater vigilance from judges and communication between courts. ${ }^{66}$

We find this conclusion impossible to reconcile with the objective facts about litigation outcomes for representative stockholders. The descriptions of current multi-forum

\footnotetext{
${ }^{62}$ As previously noted, most deal litigation settlements currently involve payment only of plaintiffs' counsel fees, and such payment is typically made by the corporation. WOLFE \& PITTENGER, supra note 42, §9.05[g] (stating that in settlements of derivative actions in which the corporation is benefited, the corporation typically pays the fee awarded, and in class actions involving a "therapeutic benefit" to a class of stockholders, the corporation is always typically ordered to pay the fee, "seemingly for lack of a pragmatic alternative”).

${ }^{63}$ Griffith \& Lahav, supra note 2.

${ }^{64} \mathrm{Id}$. at *6.

${ }^{65} \mathrm{Id}$. at *27-32.

${ }^{66} \mathrm{Id}$. at *59-71.
} 
corporate litigation suggest that the extraction of economic rents and imposition of deadweight costs are a substantial problem. The solution proposed by Professors Griffith and Lahav characterizes these rents and costs as part of a well-functioning and beneficial market system. ${ }^{67}$ We believe that the appropriate response is to reexamine and, if necessary, readjust the jurisdictional and venue rules that make these rents and costs possible. We recognize, of course, that any adjustment of the governing rules will operate only at the margin, and will not eliminate all potential for uncertainty and all misapplication of legal rules by judges dealing with multi-forum competition. We believe, however, that rules ultimately do make a difference, and that improving those rules to narrow the potential for inefficiencies in the handling of multi-forum litigation will at least reduce the costs of that litigation to the investors it is supposed to benefit and society as a whole. ${ }^{68}$ At a minimum, such improvements may reinforce the ability and willingness of judges to rein in inefficient shareholder representative litigation in the face of incentives to avoid such policing. ${ }^{69}$

\section{The Doctrinal Origins of the Multi-forum Litigation Problem}

\section{A. Overview}

In this section, we describe in modest detail the doctrines that determine the appropriate forum and the applicable law in American civil litigation, with an emphasis on corporate disputes. Because our argument focuses on corporate cases, our analysis

\footnotetext{
${ }^{67} I d$. at $* 43-50$.

${ }^{68}$ The New York City Bar Association has suggested a federal statute that would provide that any challenge to a proposed transaction could only be brought "in the courts of the state of the company's incorporation." Committee on Securities Litigation, Coordinating Related Securities Litigation: A Position Paper, Association of THE BAR OF THE CitY OF NEW YoRK, at *9-10 (Apr. 17, 2008), http://www.nycbar.org/pdf/report/Securities_Litigation_\%20A.pdf. Another solution would be to amend SLUSA to require that shareholder derivative actions may only be filed in the courts of the defendant company's state of incorporation. See Pincus, supra note 2, at 9. Congress could also prevent the multiplication of federal suits by requiring that any law suits relating to mergers or acquisitions that are filed in federal court should be transferred to a federal court in the state of incorporation of the target company, with any questions of state law then referred to that state's own courts. See id.

${ }^{69}$ See supra text accompanying notes 61 and 62.
} 
centers upon state courts; and, because state courts are tribunals with general jurisdiction, we do not discuss subject matter jurisdiction here. Rather, we focus on personal jurisdiction, choice of law, and the internal affairs doctrine.

Our description covers both the contemporary system and its nineteenth century precursors. The problem of how to allocate jurisdiction over a dispute is not a new dilemma, but is rather a fundamental issue that originates from the unique design of the American federal system. Unlike the unitary English system from which it sprang, ${ }^{70}$ the federal constitution adopted in 1787 raised the novel question of how to limit the various constituent states’ ability to exercise jurisdiction over non-citizens. ${ }^{71}$ In other words, a balancing issue arose: how to allocate lawsuits among the states in a way that would minimize costs to parties interacting across a large country, on one hand, and secure each state's prerogative to adjudicate matters of legitimate local concern, on the other.

Accompanying that issue was the related question of which state's law applied to a dispute that spanned state boundaries.

In brief, this section traces the development of jurisdictional doctrines from the nineteenth century's static territorial approach to the flexible system inaugurated in the twentieth. As exemplified in Pennoyer v. Neff, the approach to personal jurisdiction that emerged over the course of the nineteenth century strictly confined a court's exercise of

\footnotetext{
${ }^{70}$ See Harold L. Korn, The Development of Judicial Jurisdiction in the United States: Part I, 65 BRoOKLYN L. REV. 935, 971 (1999) (“In England's single realm ... [e]xtraterritorial contacts needed no consideration. The authority of the King's courts ran throughout the realm, and — apart from the constant struggles among English courts over subject matter jurisdiction in purely English cases-territorial factors (though sometimes spoken of in the language of 'jurisdiction') actually concerned only internal administrative matters that we would today recognize as problems of venue of the reach of a local officer's authority to serve process.").

${ }^{71}$ See Forest McDonald, Novus Ordo Seclorum: The InTEllectual Origins OF THE CONSTITUTION 276 (1985) ("The constitutional reallocation of powers created a new form of government, unprecedented under the sun. Every previous national authority either had been centralized or else had been a confederation of sovereign constituent states. The new American system was neither one nor the other: it was a mixture of both.”).
} 
jurisdiction to the geographic borders of the state in which it was located. ${ }^{72}$ A defendant who did not consent to jurisdiction would not have to face a suit in a state in which he was not a resident or did not have property. In the corporate context, the internal affairs doctrine, developed during the same time period, complemented the territorial approach, acting as a jurisdictional bar to adjudicating disputes relating to the governance of foreign corporations. Also complementing this system were choice of law rules that tied the law applicable to a dispute to the territory in which the event leading to the cause of action occurred. Parallel suits appear to have been uncommon during this time period, ${ }^{73}$ unsurprising given personal jurisdiction's strict territorial limitations and the local scope of most economic activity. Overall, the nineteenth century's system has been described as rigid, often in a pejorative sense. ${ }^{74}$ But it worked reasonably well at the time, when interstate commerce was still relatively insubstantial.

By the middle of the twentieth century, this static territorial approach to jurisdiction was replaced with a more flexible approach that allowed the exercise of jurisdiction so long as a defendant had “minimum contacts” with a forum state. Contemporaneously, the internal affairs doctrine was relaxed from a jurisdictional bar to a choice of law doctrine. Furthermore, the choice of law determination underwent an evolution similar to the introduction of minimum contacts analysis, changing from a

\footnotetext{
7295 U.S. 714 (1877).

${ }^{73}$ See infra Subsection II.B.4.

${ }^{74}$ See, e.g., Hanson v. Denckla, 357 U.S. 235, 250-51 (1958) (“The requirements for personal jurisdiction over nonresidents have evolved from the rigid rule of Pennoyer $v$. Neff to the flexible standard of International Shoe Co. v. Washington.”); Douglas D. McFarland, Drop the Shoe: A Law of Personal Jurisdiction, 68 Mo. L. Rev. 753, 753 (2003) ("Pennoyer held that an unwilling, nonresident defendant must be served within the boundaries of the state. During the ensuing sixty-eight years, courts struggled with application of this rigid principle to an expanding and increasingly mobile economy . ...”); D. Curtis Webster, State Court Jurisdiction After Shaffer v. Heitner: The Lingering Problems, 15 WiLlamETTE L. REV. 281, 284 (1979) ("Justice Fields recognized that Pennoyer's analysis of strict territoriality would prevent the exercise of state judicial authority in . . . instances where jurisdiction would be desirable.”).
} 
territorial assessment to an examination of which state had the "most significant relationship" with the matter. These changes had the practical effect of expanding courts' ability to exercise jurisdiction over foreign defendants and to interpret other states' laws when doing so. The twentieth century's approach retained Pennoyer's focus on geography but replaced the prior system of rigid jurisdictional boundaries with a fluid case-by-case assessment of a defendant's connections to a given forum. At the same time, representative actions became frequent and plaintiffs began to file parallel actions in multiple forums with regularity. In other words, previously separate trends-the loosening of personal jurisdiction's territorial limits and the growing popularity of the representative lawsuit—combined to create a situation where defendants faced a number of repetitive lawsuits in a variety of forums.

As will be discussed in detail in Part III, offsetting this expansion was the development of the concept of forum non conveniens, a discretionary doctrine that allowed a court to decline to exercise jurisdiction in situations where physical distance prejudiced defendants. ${ }^{75}$ Courts also began to employ the first-filed rule, the modern equivalent to the nineteenth century's abatement doctrine, to determine the appropriate forum in the increasing number of parallel cases being filed on their dockets, a result of representative litigation's spectacular growth during this time period. But, as we explain later, those efforts to limit the exercise of jurisdiction have been ineffective, and the expansion of jurisdiction described here, and the resulting increase in multi-forum litigation, has continued.

\footnotetext{
${ }^{75}$ Other tools for addressing the problem of expanding jurisdictional rules were also developed during this time, namely the federal doctrines of abstention, anti-suit injunctions, etc. We focus here on forum non conveniens owing to its centrality and because it can serve as a proxy for other similar doctrines, which are based on many of the same principles.
} 
The purpose of this section is not to present a comprehensive treatment of the history of American procedure relating to the exercise of jurisdiction and conflict of laws, which is an undertaking that has been done well at a general level already. ${ }^{76}$ Rather, the brief, functionalist historical account presented here ${ }^{77}$ shows that the problems of allocating jurisdiction among states is a problem as old as our republic, and that solutions to that problem have evolved as our national economy has matured. In that sense, the suggested reforms we discuss later are another step in a continual process of adjustment and improvement. Indeed, our argument can be understood as another measured step in the historical movement away from understanding commerce as a geographicallybounded activity.

\section{B. The Original System of Territorially Determined Jurisdiction}

For our purposes, the system for allocating jurisdiction among the states that emerged over the course of the nineteenth century had two salient characteristics. First, the analysis of whether to exercise jurisdiction was a formalistic inquiry as to where a defendant lived in relation to static geographical boundaries. Second, the choice of forum decision and the choice of law decision were intertwined, because the "vested rights” theory for choosing applicable law also looked to where a dispute fell within geographic boundaries. As is discussed below, these approaches were rooted in a concern for state sovereignty and coincided with economic activity that was often local in scale.

\footnotetext{
${ }^{76}$ See, e.g., ROBERT A. LeFlar ET Al., AMERICAN CONFLICTS LAW (4th ed. 1986); EUgENE F. SCOLES ET AL., CONFLICT OF LAWS (4th ed. 2000).

${ }^{77}$ We recognize that history rarely unfolds according to a neat, logical pattern. But, given the purpose of this article and the brevity with which we must treat the historical record, we consider a purposive interpretation of the relevant doctrines' development an efficient proxy for a more searching inquiry.
} 


\section{Pennoyer v. Neff and Its Antecedents}

Early American courts had little upon which to rely when confronting the

question of how to allocate jurisdiction among the sister states. Other than providing that

a sister state's obligations and decisions should be given full faith and credit, ${ }^{78}$ the

Constitution was silent on the question of the state courts' ability to exercise

jurisdiction. ${ }^{79}$ Shortly after the Constitution's adoption, Congress passed the Full Faith

and Credit Act of 1790, but it was a brief piece of legislation that did not address the

question of the scope of state court jurisdiction. ${ }^{80}$ Thus, constitutional and statutory

guidance was limited. ${ }^{81}$

Nevertheless, courts began fashioning a doctrine, well before the Pennoyer case, that a court could only exercise jurisdiction over persons or property located within its state’s territorial borders. ${ }^{82}$ As that position developed in both federal and state opinions, ${ }^{83}$ two related explanations for applying territorial jurisdiction became typical:

\footnotetext{
${ }^{78}$ U.S. CONST. art. IV, § 1.

${ }^{79}$ See Roger H. Trangsrud, The Federal Common Law of Personal Jurisdiction, 57 GEO. WASH. L. ReV. 849, 851 (1989) ("After the Constitution was ratified, a citizen of Massachusetts presumably had a different political relationship with Connecticut than with France, but exactly how it differed was unclear. ... [The Constitution] did not . . . directly address the authority of state courts to adjudicate the rights of noncitizens.”).

${ }^{80}$ See Act of May 26, 1790, ch. 11, 1 Stat. 122.

${ }^{81}$ Early American courts were perhaps not writing on an entirely clean slate. Although a subject of scholarly debate, it is possible to discern territorial jurisdiction's origins in English decisions dating to the fifteenth century. Burnham v. Superior Court, 495 U.S. 604, 608-09 (1990) (citing Bowser v. Collins, (1482) 145 Eng. Rep. 97 (Ex. Ch.), and Case of the Marshalsea, (1612) 77 Eng. Rep. 1027 (K.B.) 1041; 10 Coke Rep. 68b, 77a. But see Albert A. Ehrenzweig, The Transient Rule of Personal Jurisdiction: The "Power" Myth and Forum Conveniens, 65 YALE L. J. 289 (1956) (questioning English tradition as source of American territorial jurisdiction doctrine); Geoffrey C. Hazard, Jr., A General Theory of State-Court Jurisdiction, 1965 S. Cт. REV. 241, 253-60 (same); James Weinstein, The Early American Origins of Territoriality in Judicial Jurisdiction, 37 ST. LOUIS U. L. J. 1 (1992) (same).

${ }^{82}$ As early as 1813, Justice Johnson's dissenting opinion in the U.S. Supreme Court's decision in Mills v. Duryee gave a clear articulation of the justification behind the rule: "[J]urisdiction cannot be justly exercised by a state over property not within the reach of its process, or over persons not owing them allegiance or not subjected to their jurisdiction by being found within their limits.” 11 U.S. (7 Cranch) 481, 486 (1813) (Johnson, J., dissenting) (finding a judgment against an out-of-state defendant to be appropriate because the defendant had been served with process in the forum state).

${ }^{83}$ For illustrative federal decisions, see Picquet v. Swan, 19 F. Cas. 609, 614-15 (C.C.D. Mass. 1828);

D’Arcy v. Ketchum, 52 U.S. (11 How.) 165, 174-75 (1850); Boswell's Lessee v. Otis, 50 U.S. (9 How.)
} 
first, allowing a court to exercise jurisdiction over an out-of-state defendant would be unfair where the out-of-state defendant would be unaware of the suit because service of process could not occur outside of the state's boundaries; ${ }^{84}$ and second, allowing the extra-territorial exercise of jurisdiction would interfere with a foreign state’s sovereignty. ${ }^{85}$ Thus, by the time Pennoyer was decided in 1877 , a common law principle favoring territorial jurisdiction had been developed at both the federal and state level. The Pennoyer decision consolidated this precedent and tied it to the Fourteenth Amendment, which was adopted less than ten years earlier. As every first year law student knows, but as most lawyers eventually forget, the issue in Pennoyer was whether

336, 350 (1850); Thompson v. Whitman, 85 U.S. 457 (1873); Sarchet v. The General Isaac Davis, 21 F. Cas. 484, 485 (C.C.E.D. Pa. 1838); Whitaker v. Bramson, 29 F. Cas. 947, 951-52 (C.C.S.D.N.Y. 1827). Illustrative state decisions include: Kilburn v. Woodworth, 5 Johns. 37 (N.Y. 1809); Bissel v. Briggs, 9 Mass. 461 (1813); Bigger v. Hutchings \& Smith, 2 Stew. 445, 447-48 (Ala. 1830); Holt v. Alloway, 2 Blackf. 108, 109 (Ind. 1827); Delano v. Jopling, 11 Ky. 117, 119 (1820); Wernwag v. Pawling, 5 G. \& J. 500, 507-10 (Md. 1833); Whittier v. Wendell, 7 N.H. 257, 258-59 (1834); Borden v. Fitch, 15 Johns. 121 (N.Y. 1818); Grumon v. Raymond, 1 Conn. 40 (1814); Starbuck v. Murray, 5 Wend. 148, 152-60 (N.Y. Sup. Ct. 1830); Dunn v. Dunn, 4 Paige 425 (N.Y. Ch. 1834); Evans v. Instine, 7 Ohio 273 (1835); Steel v. Smith, 7 Watts \& Serg. 447 (Pa. 1844). See generally 1 JAMES KeNT, COMMENTARIES ON AMERICAN LAW 281 (1832) ("It is only when the jurisdiction of the court in another State is not impeached, either as to the subject-matter or the person, that the record of the judgment is entitled to full faith and credit. The court must have had jurisdiction not only of the cause, but of the parties, and in that case the judgment is final and conclusive.").

${ }^{84}$ See, e.g., D’Arcy, 52 U.S. at 174 (holding that a New York judgment against an out-of-state defendant who was not served with process was void, reasoning that allowing such would prejudice defendants "who reside elsewhere, and who are ignorant of the proceeding," and noting that "countries foreign to our own disregard a judgment merely against the person, where he has not been served with process nor had a day in court.”); Kilburn, 5 Johns. at 41 ("To bind a defendant personally by a judgment when he was never personally summoned, or had notice of the proceedings, would be contrary to the first principles of justice.”); see also Borden, 15 Johns. at 141-44 (discussing related decisions from English courts and other U.S. federal and state courts).

${ }^{85}$ As Justice Story, who wrote the majority opinion in Mills v. Duryee, later explained:

The first and most general maxim or proposition is that . . . every nation possesses an exclusive sovereignty and jurisdiction within its own territory. The direct consequence of this rule is, that the laws of every state affect, and bind directly all property, whether real or personal, within its territory; and all persons, who are resident within it, whether natural or born subjects, or aliens; and also all contracts made, and acts done within it. ...

Another maxim, or proposition, is that no state or nation can, by its laws, directly affect, or bind property out of its own territory, or persons not resident therein, whether they are natural born subjects, or others. This is a natural consequence of the first proposition; for it would be wholly incompatible with the equality and exclusiveness of the sovereignty of any nation, that other nations should be at liberty to regulate either persons or things within its territories.

JOSEPH STORY, COMMENTARIES ON THE CONFLICT OF LAWS §§ 17, 20 (1834). 
an Oregon court had jurisdiction over a non-resident defendant when it issued a default judgment against him. ${ }^{86}$ Although the defendant owned land in Oregon at the time the suit commenced, that property was not formally attached to the proceeding. ${ }^{87}$ Because the property was not properly attached, the Supreme Court held that the default judgment had been issued without appropriate quasi in rem jurisdiction and was therefore void. ${ }^{88}$

The reasoning behind that holding focuses on a state's control of its territory:

[E]very State possesses exclusive jurisdiction and sovereignty over persons and property within its territory. As a consequence, every State has the power to determine for itself the civil status and capacities of its inhabitants; to prescribe the subjects upon which they may contract, the forms and solemnities with which their contracts shall be executed, the rights and obligations arising from them, and the mode in which their validity shall be determined and their obligations enforced. ... The other principle of public law referred to follows from the one mentioned; that is, that no State can exercise direct jurisdiction and authority over persons or property without its territory. ... . The several States are of equal dignity and authority, and the independence of one implies the exclusion of power from all others. And so it is laid down by jurists, as an elementary principle, that the laws of one State have no operation outside of its territory, except so far as is allowed by comity; and that no tribunal established by it can extend its process beyond that territory so as to subject either persons or property to its decisions. ${ }^{89}$

As applied in the cases following Pennoyer, but before the Supreme Court's

International Shoe decision, territorial jurisdiction created a system where the available

forums in which a plaintiff could bring an action were limited to places where the

\footnotetext{
${ }^{86}$ Pennoyer v. Neff, 95 U.S. 714, 719-20 (1877).

${ }^{87} \mathrm{Id}$.

${ }^{88}$ Id. at 722.

${ }^{89} I d$. (emphasis added). The opinion then grounded this territorial view of jurisdiction in the Fourteenth Amendment: "Since the adoption of the Fourteenth Amendment to the Federal Constitution, the validity of such judgments may be directly questioned, and their enforcement in the State resisted, on the ground that proceedings in a court of justice to determine the personal rights and obligations of parties over whom that court has no jurisdiction do not constitute due process of law.” Id. at 733.
} 
defendant was a resident, held property, or consented to jurisdiction (which includes a plaintiff's temporary presence in a jurisdiction, so-called “tag” jurisdiction). ${ }^{90}$

\section{The "Vested Rights" Approach to Choice of Law Decisions}

By the end of the nineteenth century, choice of law decisions were also being made by examining how a dispute related to territorial boundaries. ${ }^{91}$ From the principle that a state has exclusive jurisdiction over its territory, ${ }^{92}$ Joseph Beale developed the theory that "only the law of the state where the rights vested may be properly applied to adjudicate the private dispute." 93 As Beale explained, because "the power of a state is supreme within its own territory ... [i]t follows that no statute has force to affect any person, thing, or act . . . outside the territory of the state that passed it." ${ }^{94}$ To interpret and apply the laws of another state, under whose law the rights at issue in the dispute “vested,” was an affront to that state’s sovereignty.

The vested rights approach appeared in a number of decisions, most notably the Supreme Court's Slater v. Mexican National Railroad Co. opinion, ${ }^{95}$ and the Restatement (First) of Conflict of Laws. According to the Restatement's formulation, rights vested

\footnotetext{
${ }^{90}$ See Riverside \& Dan River Cotton Mills v. Menefee, 237 U.S. 189, 193 (1915) (“[C]ourts of one state cannot, without a violation of the due process clause, extend their authority beyond their jurisdiction so as to condemn the resident of another state when neither his person nor his property is within the jurisdiction of the court rendering the judgment, since that doctrine was long ago established by the decision in Pennoyer v. Neff."); First Nat. Bank of Rome, Ga. v. First Nat. Bank of Jasper, Fla., 264 F. 83, 84 (5th Cir. 1920), aff'd, 258 U.S. 112 (1922) ("It is settled that constructive service can only bring nonresidents within the jurisdiction of a court where there is a res in the control of the court in which the nonresident has an interest, and then only for the sole purpose of adjudicating his rights, if any, to the res. This is the extent of the jurisdiction of a court to proceed upon substituted service, in the absence of personal service or appearance.”) (citations omitted). For personal jurisdiction cases based on tag jurisdiction, see Burnham $v$. Superior Court, 495 U.S. 604, 612-13 (1990), which catalogues numerous cases in the nineteenth and early twentieth century that permitted a court to retain personal jurisdiction over a defendant that was only temporarily in the state, but personally served in it.

${ }^{91}$ For a concise review of early American choice of law jurisprudence leading up to Beale's introduction of vested rights theory towards the end of the 19th century, see SCOLES ET AL., supra note 76, at §2.7.

${ }^{92}$ See STORY, supra note 52, at $\S 18$, at 19.

${ }^{93} 1$ Joseph H. BEALE, A TREATISE ON THE CONFLICT OF LAWS 311-12 (1935).

${ }^{94} \mathrm{Id}$.

95194 U.S. 120, 126 (1904) (“[T]he only source of this obligation is the law of the place of the act.”).
} 
under the law of the place where the event creating the cause of action occurred-in a tort case, this was the place of injury; ${ }^{96}$ in a contract case, the place of formation; ${ }^{97}$ in a

property dispute, the situs of the real property. ${ }^{98}$ In that sense, the analysis was similar to Pennoyer's approach in that it also focused on a dispute's relationship with territorial boundaries. And, like the Pennoyer system, the rules of the First Restatement have been described as "rigid," providing predictability yet failing to accommodate cases that defied confinement to a single territory. ${ }^{99}$

\section{The Internal Affairs Doctrine as Jurisdictional Bar}

Initially, the Pennoyer system applied to individuals and corporations alike.

Through the middle of the nineteenth century, opinions adhered to territorial logic in the corporate context, holding that a corporation could only be sued in the state where it was chartered or held property. ${ }^{100}$ But, during the latter part of the century, courts began to construct a rule allowing corporate defendants to be sued outside of their chartering state if they were doing business in the forum state. ${ }^{101}$

\footnotetext{
${ }^{96}$ RESTATEMENT (FIRST) OF CONFLICT OF LAWS § 378 (1934).

${ }^{97} I d . \S 332$.

${ }^{98} I d . \S \S 211,214,216-23$.

${ }^{99}$ SCOLES ET AL., supra note 76, at §2.7, at 21 n.19.

${ }^{100}$ The Supreme Court's decision in Bank of Augusta v. Earle is the leading case in this regard. See 38 U.S. 519 (1839).

${ }^{101}$ Two related theories were developed in the latter half of the 19th century. First, courts articulated a consent-based theory, which reasoned that corporations consented to jurisdiction in a state where they were doing business. See, e.g., Lafayette Ins. Co. v. French, 59 U.S. (18 How.) 404 (1856); St. Clair v. Cox, 106 U.S. 350 (1882); St. Louis Sw. Ry. v. Alexander, 227 U.S. 218, 226-27 (1913). Second, courts developed a presence-based theory, which reasoned that corporations were subject to jurisdiction if they were physically present in the state at the time of suit. See, e.g., Phila. \& Reading Ry. Co. v. McKibbin, 243 U.S. 264, 265 (1917) ("A foreign corporation is amenable to process to enforce a personal liability, in the absence of consent, only if it is doing business within the State in such manner and to such extent as to warrant the inference that it is present there.”). These jurisdiction-expanding theories developed as it became "increasingly apparent that corporations were not going to confine their business activities to the state in which they were incorporated and that restricting suit against them to a single jurisdiction was both unrealistic and unfair.” 4 Charles Alan Wright et Al., Federal Practice AND Procedure: Federal RULES Of CIVIL Procedure § 1066 (3d ed. updated 2012) [hereinafter Wright \& Miller].
} 
Despite that precedent, corporate defendants were not entirely exposed to foreign litigation. The internal affairs doctrine, developed as the corporate form grew in popularity, required that disputes over a corporation's governance be resolved in the incorporating state's courts. As an early New York case put it, under the internal affairs doctrine "[w]e can enforce no forfeiture of charter for violation of law; nor can we remove directors for misconduct. These powers all properly belong to the courts of the state from which they derive their existence." ${ }^{102}$ In other words, as courts began to exercise jurisdiction over corporate defendants in certain cases, such as those sounding in tort, the internal affairs doctrine required them to defer to the courts of the chartering state in cases involving the corporation's internal relations, where the chartering state's interests and laws were considered paramount. For our purposes, the important aspect of the internal affairs doctrine at this stage in its history was that it operated not only as a choice of law rule, but also as a jurisdictional bar. ${ }^{103}$

The internal affairs doctrine coincided with a territorial conception of corporate law. Corporations were originally considered adjuncts of the states in which they were chartered; ${ }^{104}$ up until the mid-nineteenth century, corporations could typically only

\footnotetext{
${ }^{102}$ Howell v. Chi. \& Nw. Rwy. Co., 51 Barb. 378, 378 (N.Y. Sup. Ct. 1868).

${ }^{103}$ See, e.g., N. State Copper \& Gold Mining Co. v. Field, 20 A. 1039, 1040 (Md. 1885); Wilkins v. Thorne, 60 Md. 253 (1883); Smith v. Mutual Life Ins. Co., 96 Mass. 336 (1867); Williston v. Mich. S. \& N. Ind. R.R. Co., 95 Mass. 400 (1866); Erickson v. Nesmith, 86 Mass. 233 (1862); Redmond v. Enfield Mfg. Co., 13 Abb. Pr. (n.s.) 332 (N.Y. Sup. Ct. 1872); Howell v. Chicago \& Nw. Ry. Co., 51 Barb. 378 (N.Y. Sup. Ct. 1868); Madden v. Penn. Electric Light Co., 37 A. 817 (1897). See generally 17 WILLIAM MEADE FLETCHER ET. AL., FLETCHER CYCLOPEDIA OF THE LAW OF PRIVATE CORPORATIONS $§ 8425$ (updated ed. 2012); RESTATEMENT (FIRST) OF CONFLICT OF LAWS §§ 196, 197, 199 (1934).

${ }^{104}$ Corporations were originally chartered for a particular purpose and through specific legislation. See Frederick Tung, Before Competition: Origins of the Internal Affairs Doctrine, 32 J. CORP. L. 33, 46-47 (2006) ("Incorporation was not generally available to all who applied; instead, corporate charters were granted only sparingly, one-by-one, through special acts of state legislatures. Each act was specifically tailored to the particular project proposed, with powers and privileges specifically defined. Not only were business corporations 'creatures' of the state-in the sense that they came into existence through specific acts of state legislatures - but through the early part of the nineteenth century, they were viewed as agencies of the state.”). Even as Jacksonian populism introduced general incorporation, or the ability to
} 
operate within the confines of their chartering state. ${ }^{105}$ And, even as corporations later gained the ability to freely operate throughout the country, that respect for state sovereignty remained. ${ }^{106}$ As the Supreme Court stated in its 1933 decision in Rogers v. Guaranty Trust Co. of New York, "[i]t has long been settled doctrine that a court—state or federal—sitting in one State will as a general rule decline to interfere with or control by injunction or otherwise the management of the internal affairs of a corporation organized under the laws of another state but will leave controversies of such matters to the courts of the state of the domicile.”107 There was a conceptual consistency between corporate law and the territorial approach to personal jurisdiction and choice of law discussed above: all pinned the limits of jurisdiction to states' geographical boundaries.

anyone to seek and obtain a charter, the public-spirited nature of the corporation persisted for some time. See Currie’s Adm'rs v. Mut. Assurance Soc'y, 14 Va. (4 Hen. \& M.) 315, 347 (1808) (“[A]cts of incorporation ... ought never to be passed, but in consideration of services rendered to the public.”); Joseph K. ANGell \& SAMUel Ames, LAW of Private CoRPorations Aggregate § 13 (8th ed. 1866) ("The object in creating a corporation is, in fact, to gain the union, contribution and assistance of several persons for the successful promotion of some design of general utility .... The principle is ... that the design of a corporation is to provide for some good that is useful to the public.”); see also Pauline Maier, The Revolutionary Origins of the American Corporation, 50 WM. \& MARY Q. 51, 53 (1993) ("That a particular venture would benefit the private estates of individuals seems to have been of no concern—or to have been a positive consideration—as long as the public's welfare was also served.").

${ }^{105}$ See, e.g., Bank of Augusta, 38 U.S. at 588 ("It is very true that a corporation can have no legal existence out of the boundaries of the sovereignty by which it is created. It exists only in contemplation of law, and by force of the law; and where that law ceases to operate, and is no longer obligatory, the corporation can have no existence. It must dwell in the place of its creation, and cannot migrate to another sovereignty.”); see also Henry N. Butler, Nineteenth-Century Jurisdictional Competition in the Granting of Corporate Privileges, 14 J. LEGAL STUD. 129, 155 (1985) (“As late as the 1860s, the status of operating a corporation in a foreign jurisdiction was uncertain.”).

${ }^{106}$ See Smith, 96 Mass. at 339 (stating that the internal affairs doctrine "does not merely regard the powers of the court, but rather the extent of the state authority which underlies those powers. It is in the nature of a question of sovereignty"); Howell, 51 Barb. at 383 ("It is the duty of the state to provide for the collection of debts from foreign corporations, due to its citizens, and this has been done; and it is the duty of the state to protect its citizens from fraud, by all the means in its power, whether against domestic or foreign wrongdoers. This, however, does not authorize the courts to regulate the internal affairs of foreign corporations. The courts possess no visitorial power over them. We can enforce no forfeiture of charter for violation of law; nor can we remove directors for misconduct. These powers all properly belong to the courts of the state from which they derive their existence."); Redmond, 13 Abb. Pr. (n.s.) at 334 ("To attempt, by a judgment of this court, to compel a foreign corporation to distribute its assets among the stockholders, because some of the directors were resident here, or because some of the funds were within the jurisdiction of the court, would be assuming a power which the court ought not to exercise, and rendering a judgment which could not be enforced against the company in the place of its existence.”). 107288 U.S. 123, 130 (1933). 


\section{Infrequent Parallel Litigation and the Advent of Representative Litigation}

Given the territorial approach to jurisdiction outlined above, parallel litigation

appears to have been an infrequent occurrence during this time period, at least by

contemporary standards. It appears that, because economic activity was predominantly

local, the prototypical parallel suit situation involved estate disputes where extended

families crossed state lines ${ }^{108}$ or suits attaching a merchant's property to satisfy a debt not

only in the defendant's home jurisdiction but also in locations where the defendant's

factors transacted. ${ }^{109}$

Representative litigation was also rare. In the first half of the nineteenth century,

class actions, which had ancient origins in English chancery practice, ${ }^{110}$ became

\footnotetext{
${ }^{108}$ See, e.g., Baker v. Baker, Eccles \& Co., 242 U.S. 394 (1917) (affirming decision of Kentucky court of appeals not to grant full faith and credit to decision of Tennessee court that held that decedent was domiciled in Tennessee, and that Tennessee court could thus resolve disposition of decedent's personal property located in Kentucky); Frederick v. Milbourne, 73 So. 442 (Ala. 1916) (upholding the decision of an Alabama lower court to refuse to grant full faith and credit to court proceedings in Georgia concerning the disposition of real estate in Georgia); Selle v. Rapp, 220 S.W. 662 (Ark. 1920) (refusing to respect New Jersey court's disposition of decedent's real property in Arkansas, where decedent had executed a will in Arkansas but became a citizen of moved to New Jersey before death). See generally Bert E. Hopkins, The Extraterritorial Effect of Probate Decrees, 53 YALE L.J. 221 (1944) (discussing parallel suits in estate actions).

${ }^{109}$ See, e.g., Lindsay v. Larned, 17 Mass. 190, 190 (1821); Drake v. Bander, 8 Tex. 351, 357 (1852).

${ }^{110}$ Zechariah Chafee's classic historical analysis traced the class action's origin to the English bill of peace: Class suits began as an offshoot of bills of peace with multiple parties. A common-law action soon came to be a two-sided affair, usually with only one plaintiff and one defendant. ... [A] dispute of one person against many persons usually had to come before the law courts, if at all, in the form of many separate actions. Hence it was far cheaper and more convenient to have a single suit in chancery, which was accustomed to handle polygonal controversies. ... In such situations, each member of the multitude had the same interests at stake as every other member, so that it was an obvious waste of time to try the common question of law and fact over and over in separate actions. ... It was much more economical to get everybody into a single chancery suit and settle the common questions once and for all..... From such a bill of peace it was a natural step to the representative suit.

Zechariah Chafee, Some Problems of Equity 200-01 (1950). See also Adair v. New River Co., (1805) 32 Eng. Rep. 1153 (Ch.); 11 Ves. Jr. 429, 444 (“There is one class of cases, very important upon this subject: viz. where a person, having at Law a general right to demand service from the individuals of a large district, to his mill, for instance, may sue thus in Equity. His demand is upon every individual, not to grind corn for their own subsistence except at his mill. To bring actions against every individual for subtracting that service is regarded as perfectly impracticable. Therefore a bill is filed to establish that right; and it is not necessary to bring all the individuals: why? No, that it is inexpedient, but, that it is impracticable, to bring them all. The Court therefore has required so many, that it can be justly
} 
recognized in American equity doctrine. ${ }^{111}$ At the same time, courts in the United States

began allowing shareholders to sue on behalf of the corporation. ${ }^{112}$

said, they will fairly and honestly try the legal right between themselves, all other persons interested, and the plaintiff.”). For an alternative analysis that criticizes Chafee's reading of the cases and connects contemporary class actions to the group litigation of the twelfth to fifteenth centuries, see STEPHEN C. YeAZELl, From MEdieVAl Group Litigation to tHe Modern Class Action (1987).

English class suits before 1830 fall into three main categories. Geoffrey C. Hazard et al., An Historical Analysis of the Binding Effect of Class Suits, 146 U. PA. L. REV. 1849, 1861-78 (1998). The first is bills of peace, in which a court would resolve cases, often involving real property, that involved "a common benefit to or burden upon" the members of a group. These cases have been described as "perhaps the first recognizable expression of class suit doctrine.” Id. at 1863. The second category is creditor or legatee bills, in which the Court of Chancery would attempt to resolve the claims of all the creditors or legatees on the estate of a debtor or decedent. Id. at 1866-74. The third category—of which Adair v. New River Co. is an example-is cases in which plaintiffs filed suit against unincorporated associations, which could not be sued in their own name, but whose shareholders or members could be sued. Id. at 1874-76. The English courts did not develop a doctrine of res judicata in this period; this was an issue that was only resolved by U.S. cases a century later. Id. at 1877-78, 1925-26.

${ }^{111}$ Joseph Story pioneered representative litigation in the United States. In 1820, after reviewing English cases, he established in American law an exception to the "necessary party" doctrine, according to which all the parties with an interest in an action had to be joined in an action. Thus, in the case before him, the legatees of a decedent did not need to join all of the other interested parties in order to obtain an accounting from an executor. West v. Randall, 29 F.Cas. 718 (C.C.D.R.I. 1820) (No. 17,424). He held:

It is a general rule in equity, that all persons materially interested, either as plaintiffs or defendants in the subject matter of the bill ought to be made parties to the suit, however, numerous they may be. The reason is that the court may be enabled to make a complete decree between the parties, may prevent future litigation by taking away the necessity of a multiplicity of suits, and may make it perfectly certain, that no injustice shall be done, either to the parties before the court, or to others, who are interested by a decree, that may be grounded upon a partial view only of the real merits. . . . The rule, however, that all persons, materially interested in the subject of the suit, however numerous, ought to be parties, is not without exception. [I]t being a general rule, established for the convenient administration of justice, it must not be adhered to in cases, to which consistently with practical convenience it is incapable of application.

Id. at 721-22 (citations omitted).

Story relied in part on West when, four years later, he held that a creditor of a bank, which had become insolvent, did not need to join all the bank's former shareholders in order to recover dividends that were improperly paid out to them in violation of statute. Wood v. Dummer, 30 F.Cas. 435 (C.C.D. Me. 1824)

(No. 17,944). He summed up the exceptions to the "necessary party" doctrine thus:

The result of the whole cases is, that where the parties are so numerous, that it is inconvenient or impracticable to bring all before the court, the rule [i.e., the necessary party doctrine], which is founded on the consideration of public good, shall not be applied, since it would defeat the purposes of justice.

Id. at 439. See also JOSEPH STORY, COMMENTARIES ON EQUITY PLEADINGS §72 (1838) (stating the "general rule in equity" that "all persons materially interested, either legally or beneficially, in the subjectmatter of a suit, are to be made parties to it, either as plaintiffs or defendants, however numerous they may be, so that there may be a complete decree, which may bind them all").

The basic contours of the class action - namely, numerosity, common questions of law and fact, and fair representation-were codified in Federal Equity Rule 48, which was in force from 1842 to 1912. Fed. Equity R. 48 ("Where the parties on either side are very numerous, and cannot, without manifest inconvenience and oppressive delays in the suit, be all brought before it, the Court in its discretion may dispense with making all of them parties, and may proceed in the suit, having sufficient parties before it to represent all the adverse interest of the plaintiffs and the defendants in the suit properly before it.”). 
Despite their advent at the beginning of the nineteenth century, representative suits in the United States remained uncommon at least 100 years later. ${ }^{113}$ Due to their peripheral position in American jurisprudence, and although developed

contemporaneously, representative suits appear to have evolved without conscious consideration of their implications for the jurisdictional issues discussed above. The closest purposeful connection between jurisdictional rules and representative suits occurred occasionally in federal courts during the early nineteenth century, where the representative mechanism was used in situations where formally joining all parties to a

\footnotetext{
112 The Supreme Court recognized shareholders' ability to bring derivative suits in 1855 . Dodge v. Woolsey, 59 U.S. 331, 342 (1855) (allowing a shareholder to "maintain a bill in equity against the directors and compel the company" to refund profits); see also Hawes v. Oakland, 104 U.S. 450, 460-61 (1882) (upholding Dodge but setting a number of substantive and procedural limitations on shareholders' ability to bring derivative suits). See generally Hazard et al., supra note 110, at 1889-90 (discussing DeBaun v. Mayor of New York, 16 Barb. 392 (N.Y. App. Div. 1853), a prototypical taxpayers' derivative suit in New York); id. at 1897-1901 (discussing Smith v. Swormstedt, 57 U.S. 288 (1853), a suit against the managers of a book business that could also be regarded as a derivative suit).

English courts first heard suits by shareholders seeking relief from management action at the beginning of the nineteenth century. Adley v. Whitstable Co., (1810) 34 Eng. Rep. 122 (Ch.); 17 Ves. Jr. 316 (shareholder in an incorporated fishery was granted conditional relief against management that denied him profits). In the 1843 case of Foss v. Harbottle, English courts cut back on shareholder rights to sue derivatively on behalf of the corporation, and held that the corporation must sue instead in its own name. (1843) 67 Eng. Rep. 189 (Ch.) 203; 2 Hare 460, 493 (“[I]t is only necessary to refer to the clauses of the Act to shew that, whilst the supreme governing body, the proprietors at a special general meeting assembled, retain the power of exercising the functions conferred upon them by the Act of Incorporation, it cannot be competent to individual corporators to sue in the manner proposed by the Plaintiffs on the present record.”). The English courts carved out an exception to this general bar to derivative suits in Atwool v. Merryweather, in which it was held that a minority shareholder was permitted to sue in the name of the corporation to recover damages for a fraudulent act, where a majority of shareholders-including the directors who allegedly committed the fraud—had voted against such action. [1868] L.R. 5 Eq. 464 n.3 (Ch.). See generally Bert S. Prunty, The Shareholders' Derivative Suit: Notes on Its Derivation, 32 N.Y.U. L. REV. 980, 980-85 (1957) (discussing English origins of the derivative suit).

${ }^{113}$ YEAZELL, supra note 110, at 222. One reason for infrequent use of representative suits is that, until the twentieth century, decisions in representative litigation were not binding on class members not formally joined to the suit, which reduced much of the procedural mechanism's utility. In Supreme Tribe of Ben-Hur v. Cauble, decided in 1921, the Supreme Court ruled for the first time that "[i]f the federal courts are to have the jurisdiction in class suits to which they are obviously entitled, the decree when rendered must bind all of the class properly represented.” 255 U.S. 356, 367 (1921). Otherwise, the Court noted, a court might determine the rights of one group of class-members under one theory, and that theory might be repudiated by another court determining the rights of another group of class-members. Id. at 366-67. In Hansberry v. Lee, the Court reaffirmed Ben-Hur but noted that absent members could only be bound by the result of a class action if they were "in fact adequately represented by the parties who are present." 311 U.S. 32, 43
} (1940). 
suit would have disallowed the court from exercising its diversity jurisdiction. ${ }^{114}$ The contemporary jurisdictional issues that would arise from large shareholder classes dispersed across the nation simply did not occur with any frequency at a time when representative suits predominantly involved local parties. The local focus of these suits is evidenced in the typical purpose for which the aggregation mechanism was used at the time. Rather than being brought predominantly on tort-like claims-such as actions for trespass or trespass on the case-nineteenth century class suits were often used in property-related disputes, such as estate matters or controversies over common property. ${ }^{115}$ This is unsurprising: because most trade was limited to local geographies, harm to a large number of far-flung plaintiffs-as is typical in the modern tort class action-was a rare occurrence, and thus disputes were primarily isolated to propertyrelated matters, where the focus was on gathering all parties in a single case so as to definitively resolve claims against locally situated assets. Indeed, of this time period's leading corporate cases, few if any arose as representative actions. ${ }^{116}$

\footnotetext{
${ }^{114}$ In 1806, the Supreme Court ruled that federal courts only had diversity jurisdiction if all the plaintiffs were citizens of different states than all the defendants. Strawbridge v. Curtiss, 7 U.S. (3 Cranch) 267 (1806). Federal jurisdiction in the nineteenth century was "primarily diversity jurisdiction," but the "necessary parties" doctrine acted as a bar to federal court, because joining large numbers of plaintiffs or defendants increased the chance of destroying diversity. Hazard et al., supra note 110, at 1882. Representative suits, where only the citizenship of the named party was relevant to determining diversity, therefore acted as an "avenue of escape" from the necessary parties doctrine. Id. at 1883.

${ }^{115}$ See, e.g., McArthur v. Scott, 113 U.S. 340 (1885) (dispute over validity of will); Swormstedt, 57 U.S. 288 (dispute over ownership of book publishing business); Randall, 29 F.Cas. 718 (accounting action by legatees against executor).

${ }^{116}$ Cf. N. State Copper \& Gold Min., 20 A. 1039, 1040 (Md. 1885) (suit by single stockholder complaining that charge assessed by corporation on shareholders was illegal and void, and seeking to recover the stock he had forfeited by not paying charge); Wilkins v. Thorne, 60 Md. 253, 254 (1883) (complaint by single stockholder against the president of the North State Copper and Gold Mining Company, arguing that the president had defrauded the stockholders); Williston v. Mich. S. \& N. Ind. R.R. Co., 95 Mass. 400 (1866) (suit by single stockholder seeking payment of guaranteed dividends); Smith v. Mut. Life Ins. Co., 96 Mass. 336, 339 (1867) (suit by single complainant seeking to be restored to his rights under a life insurance policy issued by defendant).
} 


\section{Summary}

By the end of the nineteenth century, the modern interstate economy that had developed in the United States relied on a legal system that organized its judiciary into exclusive compartments according to state boundaries. The principle behind this organization was the territorial theory of jurisdiction, which was developed over the course of the century and culminated in the Supreme Court's 1877 Pennoyer decision. In essence, that theory precluded courts from exercising jurisdiction over an individual or entity without a physical presence within the boundaries of the state. Complementing Pennoyer's approach to personal jurisdiction were the territory-based vested rights choice of law rule and the internal affairs doctrine, which operated as a jurisdictional bar where plaintiffs attempted to bring suits outside of a corporation's chartering state. In this system, choice of forum and choice of law were the same inquiry. That is, once one knew where the defendant was physically present or owned property, one knew both which forums were available and which laws applied. ${ }^{117}$ In this system, parallel litigation was an infrequent concern.

The nineteenth century system dealt with the fundamental problem of how to allocate jurisdiction among courts in a federal system by erecting strict boundaries between the states. This system handled a dispute that implicated multiple jurisdictions by funneling it back to the defendant's home jurisdiction. Although this approach created inequities—-the most obvious being between the tort claimant, who could only bring her case where the defendant was located and not in her local courts, and the tort defendant,

\footnotetext{
${ }^{117}$ At this time, the doctrine of forum non conveniens was not recognized outside of a few scattered opinions. See Allan Stein, Forum Non Conveniens and the Redundancy of Court-Access Doctrine, 133 U. PA. L. REV. 781, 801 (1985) (“[T] he doctrine of forum non conveniens was virtually unheard of, outside of the admiralty context, prior to 1929 ”).
} 
who did not have to worry about defending distant lawsuits even where the defendant had acted distantly—-those inequities were largely inconsequential given the local nature of most economic activity at the time. As we next discuss, later developments attempted to recalibrate the balance between plaintiffs' access to the courts with defendants' convenience while maintaining the essential characteristics of the territorial system.

\section{Extending Jurisdiction to Accommodate an Interstate Economy}

During the early 20th century, the territorial approach to allocating jurisdiction between the constituent components of the federal system began to unravel. One of the territorial approach's core assumptions—-that economic activity was largely contained within states’ political boundaries_-became untenable as commerce attained interstate scale. ${ }^{118}$ In response, courts developed a new set of doctrines that retained the territorial paradigm but assessed a given court's exercise of jurisdiction through a flexible array of factors that were thought to better accommodate commercial reality and its effects on the ability of litigants to obtain justice in the courts. Contemporaneously, the vested rights choice of law rule was abandoned for an inquiry that determined the applicable law by examining which state had the most significant relationship with the dispute. The internal affairs doctrine was also relaxed, changing from a jurisdictional bar to a mere

\footnotetext{
${ }^{118}$ See, e.g., 4 WRIGHT \& MILLER, supra note 101, § 1065 ("In the years following the seminal decision in Pennoyer v. Neff, it became apparent that to limit in personam jurisdiction to those situations in which an individual defendant could be served personally within the territory of the forum state or had consented to the jurisdiction of the courts of that state was inadequate in a society that was becoming increasingly complex. Accordingly, as modes of transport and communication improved and the mobility of American citizens increased, so did the pressure on state legislatures and the courts to develop broader bases for asserting jurisdiction over individuals who were beyond the territorial limits of the state at the time of suit.”). For the growth in interstate commerce in this period, see, for example, Sukkoo Kim, Expansion of Markets and the Geographic Distribution of Economic Activities: The Trends in U.S. Regional Manufacturing Structure, 1860-1987, 110 Q.J. ECON. 885-86 (1995) (discussing the rapid integration of U.S. regions following advances in transportation and information transmission).
} 
choice of law rule. Thus, the range of actions over which a court could exercise jurisdiction was expanded.

\section{The Minimum Contacts System of Personal Jurisdiction}

Although decisions following Pennoyer advanced theories for allowing courts to exercise jurisdiction over defendants doing business in the forum, ${ }^{119}$ no reformulated jurisdictional test was clearly articulated until the Supreme Court’s 1945 decision in International Shoe. ${ }^{120}$ That decision and its progeny ${ }^{121}$ established a test whereby jurisdiction could be exercised over a defendant who had "minimum contacts" with the forum in question, so long as the exercise of jurisdiction did not offend "traditional notions of fair play and substantial justice.”122 Although later cases would clarify that territorial boundaries were still relevant to the jurisdictional analysis, ${ }^{123}$ International Shoe's rule provided a basis for expanding the range of out-of-state defendants over which a court could exercise jurisdiction. At the state level, a corresponding expansion of jurisdiction was accomplished through the enactment of long-arm statutes, which typically have either (1) allowed a court to exercise jurisdiction if a minimum contacts

\footnotetext{
${ }^{119}$ See supra note 66 and accompanying text.

${ }^{120}$ Int'l Shoe Co. v. Washington, 326 U.S. 310 (1945).

${ }^{121}$ E.g., Burger King Corp. v. Rudzewicz, 471 U.S. 462 (1985); World-Wide Volkswagen Corp. v. Woodson, 444 U.S. 286 (1980); Shaffer v. Heitner, 433 U.S. 186 (1977); Hanson v. Denckla, 357 U.S. 235 (1957); McGee v. Int’l Life Ins. Co., 355 U.S. 220 (1957).

${ }^{122}$ Int'l Shoe, 326 U.S. at 316. At first glance, the International Shoe test may not appear that different from the earlier consent- and presence-based theories, which predicated the exercise of jurisdiction on a defendant's contacts with the forum state. But, "the old test looked to a quantum of activities sufficient to establish a basis of jurisdiction for all suits, whereas [International Shoe's] approach made jurisdiction depend on all of the circumstances of the particular case.” Note, State-Court Jurisdiction, 73 HARV. L. Rev. 911, 923 (1960).

${ }^{123}$ See, e.g., World-Wide Volkswagen, 444 U.S. at 293 (“[W]e have never accepted the proposition that state lines are irrelevant for jurisdictional purposes, nor could we and remain faithful to the principles of interstate federalism embodied in the Constitution.”).
} 
test similar to International Shoe's is satisfied or (2) enumerated the in-state activities that would provide the basis for the exercise of personal jurisdiction. ${ }^{124}$

For our purposes, the important characteristic of the International Shoe system is not just that it expanded courts’ jurisdictional reach but that it reinterpreted Pennoyer's focus on fixed territorial limits into a fact-specific inquiry into a defendant's connection with the forum state's geographic boundaries. The physical location of a defendant and its activities remained the hallmark of the system. The fundamental change was that the geographic analysis, which had involved an examination of static boundaries under Pennoyer, was conducted on a case-by-case basis after International Shoe.

\section{2. “Most Significant Relationship” Choice of Law Analysis}

Determining what law was applicable to a dispute underwent a similar change during the 20th century that persists to this day. Whereas the prior system analyzed where the event precipitating the dispute occurred in an attempt to determine under which state’s laws the rights at issue vested, choice of law decisions in the current system are made by assessing which state has the “most significant relationship” to the dispute. ${ }^{125}$ The "most significant relationship" test is found throughout the Restatement (Second) of Conflict of Laws, which softens the First Restatement's rigid territorial rules into openended directives that allow a court to consider a number of factors when determining the applicable law. ${ }^{126}$ Although there are exceptions, the majority of states have followed

\footnotetext{
${ }^{124}$ Of the former, California's long-arm statute, which simply provides that "[a] court of this state may exercise jurisdiction on any basis not inconsistent with the Constitution of this state or of the United States," is a good example. CAL. Civ. PROC. CODE $§ 410.10$. New York's long-arm statute is an example of the latter. See N.Y. C.P.L.R. 302. Illinois's long-arm statute incorporates both approaches. 735 ILL. CoMP. STAT. 5/2-209 (2008).

${ }^{125}$ LEFLAR ET AL., supra note 41, §109, at 303.

${ }^{126}$ See, e.g., RESTATEMENT (SECOND) OF CONFLICT OF LAWS §§ 6, 145, 188 (1971).
} 
suit, abandoning the traditional territorial rules in favor of the more flexible approach that the Second Restatement exemplifies. ${ }^{127}$

\section{The Internal Affairs Doctrine Becomes Limited to a Choice of Law Rule}

At the time the doctrines of personal jurisdiction and choice of law were being

refashioned, courts were also changing their approach to the internal affairs doctrine. As

discussed above, the internal affairs doctrine originated as a jurisdictional bar requiring

dismissal of suits involving governance questions of out-of-state corporations. ${ }^{128}$ But,

fourteen years after its decision in Rogers v. Guaranty Trust, in which it upheld the

application of the internal affairs rule as a basis to refuse to exercise jurisdiction, ${ }^{129}$ the

Supreme Court in Koster v. (American) Lumbermens Mutual Casualty Co. held that the

doctrine of forum non conveniens, not the internal affairs doctrine, should guide the

decision of whether a court should exercise jurisdiction over a foreign corporation. ${ }^{130}$

The court reasoned that whether or not the case involved the internal affairs of a foreign

corporation was “one, but only one, factor which may show convenience of parties or

witnesses, the appropriateness of trial in a forum familiar with the law of the

corporation's domicile, and the enforceability of the remedy if one be granted,” deeming

${ }^{127}$ See SCOLES ET AL., supra note 76, §§2.15-2.17 (discussing states’ abandonment of lex loci delicti and lex loci contractus rules).

${ }^{128}$ See supra notes 100 through 107 and accompanying text.

129288 U.S. 123, 130 (1933) ("It has long been settled doctrine that a court—state or federal—sitting in one State will as a general rule decline to interfere with or control by injunction or otherwise the management of the internal affairs of a corporation organized under the laws of another state but will leave controversies as to such matters to the courts of the state of the domicile.”).

130330 U.S. 518 (1947) ("There is no rule of law, moreover, which requires dismissal of a suitor from the forum on a mere showing that the trial will involve issues which related to the internal affairs of a foreign corporation. That is one, but only one, factor which may show convenience of parties or witnesses, the appropriateness of trial in a forum familiar with the law of the corporation's domicile, and the enforceability of the remedy if one be granted. But the ultimate inquiry is where trial will best serve the convenience of the parties and the ends of justice. Under modern conditions corporations often obtain their charters from states where they no more than maintain an agent to comply with local requirements, while every other activity is conducted far from the chartering state. Place of corporate domicile in such circumstances might be entitled to little consideration under the doctrine of forum non conveniens, which resists formalization and looks to the realities that make for doing justice.”). 
the forum non conveniens analysis more true to reality because "[u]nder modern

conditions corporations often obtain their charters from states where they no more than

maintain an agent to comply with local requirements, while every other activity is

conducted far from the chartering state." ${ }^{131}$ Absent from the court's opinion, however, is

an explanation for why it rejected the potential utility, in terms of party and investor

expectations, of placing importance on choice of law in considering application of the

forum non conveniens doctrine, or why the situs of a corporation's operational activity

should be deemed significant at all in relation to a legal dispute not arising out of that

activity.

Thus, although the doctrine remained applicable to choice of law decisions, it was

no longer applied as a jurisdictional bar. ${ }^{132}$ This approach was memorialized in the

${ }^{131}$ Id. at 527-28.

132 See Panama Processes, S.A. v. Cities Serv. Co., 650 F.2d 408, 419 (2d Cir. 1981) (““There is no rule of law which requires dismissal of a suitor from the forum on a mere showing that the trial will involve issues which relate to the internal affairs of a foreign corporation.' The fact that this case may involve

'complicated affairs of a foreign corporation is not alone a sufficient reason for a federal court to decline to decide it.”” (quoting Koster v. Lumbermens Mutual Co., 330 U.S. 518, 527 (1947), and Williams v. Green Bay \& W.R. Co., 326 U.S. 549, 556-57 (1946)); Burton v. Exxon Corp., 536 F. Supp. 617, 624 (S.D.N.Y. 1982) ("That an action touches upon the internal affairs of a foreign corporation does not automatically require a district court to dismiss the case and relegate the parties to a forum in the corporation's state of domicile.”); RESTATEMENT (SECOND) OF CONFLICT OF LAWS §§ 6, 313 (1971). The internal affairs doctrine has even been supplanted as a choice of law rule. For example, a California statute, Cal. Corp. Code $\S 2115$, provides that for non-California corporations, other than certain publicly traded firms, whose shareholders and revenues are attributable to California at defined levels, the California corporate statutes apply to a variety of matters including annual election of directors, the director's duty of care, director and officer indemnification, and cumulative voting. Invoking the primacy of the internal affairs doctrine as a matter of constitutional law, the Delaware Supreme Court has declined to apply Section 2115.

VantagePoint Venture Partners 1996 v. Examen, Inc..871 A.2d 1108, 1115-18 (Del. 2006) (rejecting application of $\S 2115$ to determine voting rights in a Delaware corporation). In some instances, however, and even in the absence of a statutory directive like California's $\S 2115$, courts have gone so far as to reject the internal affairs doctrine even as a basis for choosing applicable law. Thus, for example, New Jersey state courts, emphasizing business activity and participants' residence in New Jersey, have applied New Jersey's dissolution statute in cases involving corporations formed under other states' laws. Krzastek v. Global Res. Indus. \& Power, 2008 WL 4161662, at*15 n.6 (N.J. Super. App. Div. Sept. 11, 2008), cert. denied, 962 A.2d 530 (N.J. 2008) ("Even assuming that the broader remedies available to an oppressed minority shareholder are indicative of a conflict between New Jersey and Massachusetts laws, we are satisfied that under the flexible governmental-interest test, New Jersey has the greater interest. Both states have a significant interest in deterring the breach of the duty of good faith and loyalty to minority shareholders. New Jersey, however, as the state where [the defendant] maintained its headquarters, from 
Restatement (Second) Conflict of Laws, which states that "[a] court will exercise

jurisdiction over an action involving the internal affairs of a foreign corporation unless it

is an inappropriate or an inconvenient forum for the trial of the action.”133 The comments

in the Restatement describe the factors to be considered when determining whether to

exercise jurisdiction over an internal affairs case, most of which are geographic in

focus. ${ }^{134}$ For example, the Restatement prescribes weighing the "contacts” between the

defendant corporation and its chartering state, on one hand, and the defendant corporation

and the forum state, on the other hand. ${ }^{135}$ Where the corporation is "only technically a

foreign corporation, since all, or the great majority, of its contacts, other than the place of

its incorporation, are in the state of the forum” the Restatement recommends exercising

jurisdiction over disputes involving the entity’s internal governance. ${ }^{136}$ The Restatement

therefore looks behind shareholders' choice of incorporating jurisdiction to examine the

corporation's geographical relationships when deciding whether to exercise jurisdiction.

where it transacted its business to secure construction projects, hired its employees and processed its bills, had the greater interest in deterring the breach of the duty of good faith and loyalty to its minority

shareholder.); Conway v. DialAmerica Marketing, Inc., No. C-116-08, at *10 (N.J. Ch. Div. Sept. 30, 2008), available at http://www.nybusinessdivorce.com/uploads/file/Conway.pdf ("[New Jersey] courts remain free . . . to retain jurisdiction in cases involving the internal affairs of a foreign corporation and to grant relief on equitable principles wherever indicated, even to the extent of applying to a foreign corporation in a proper case certain substantive features of this Revision [of the New Jersey Business Corporations Act]. There are modern choice of law doctrines developing in this field, which the Commission did not wish to restrict by adopting the approach in [the Model Business Corporation Act].” (citations omitted) (quoting 1968 Commissioners' Comment to N.J. STAT. ANN. § 14A:13-2)); see also Ackert v. Ausman, 218 N.Y.S.2d 814, 819 (N.Y. Sup. 1961) (concluding that a shareholder action on behalf of a Nevada corporation claiming excessive investment adviser compensation "does not involve the internal affairs of a foreign corporation.”). The Supreme Court of the United States has taken a decidedly different approach from these cases, strongly adhering to internal affairs doctrine. See CTS Corp. v. Dynamics Corp. of Am., 481 U.S. 69, 90 (1987) (“Th[e] beneficial free market system [of allocating capital to corporations] depends at its core upon the fact that a corporation-except in the rarest situations-is organized under, and governed by, the law of a single jurisdiction, traditionally the corporate law of the State of its incorporation.”); Edgar v. Mite Corp., 457 U.S. 624, 645-46 (1982) (noting that a state "has no interest in regulating the internal affairs of foreign corporations”).

133 RESTATEMENT (SECOND) OF CONFLICT OF LAWS § 313 (1971).

${ }^{134}$ See id. cmt. c.

${ }^{135} \mathrm{Id}$.

${ }^{136} \mathrm{Id}$. 


\section{The Contemporaneous Expansion of Representative Litigation}

\section{As the rules governing the exercise of personal jurisdiction expanded courts'}

reach during this time period, representative actions increased in frequency. As discussed

above, the framework for the modern American class action was constructed in the nineteenth century. ${ }^{137}$ The twentieth century’s landmark procedural reform, namely the promulgation of the Federal Rules of Civil Procedure in 1938, attempted to rationalize the representative litigation rules that had been already established. ${ }^{138}$ The fundamental

\footnotetext{
137 Supra Section II.B.4.

138 The drafter of Federal Rule of Civil Procedure 23, James William Moore, claimed that he was codifying the current approach of the courts to class actions. James W. Moore \& Marcus Cohn, Federal Class Actions, 32 ILL. L. REV. 307, 325 (1937) ("Rule 23 of the Proposed Rules does not deal with Class Actions in a novel manner.”). The 1937 version of Rule 23 divided class actions into three types. FED. R. CIV. P. R. 23(a) (1937) (classifying class suits according to whether "the character of the right sought to be enforced for or against the class is (1) joint, or common . . . ; (2) several, and the object of the action is the adjudication of claims which do or may affect specific property involved in the action; or (3) several, and there is a common question of law or fact affecting the several rights and a common relief is sought”). Moore stated that these categories mapped on to categories originally used by Joseph Story, and cited American and English cases extensively to support the rules. Moore \& Cohn, supra, at 314-2; id. at 310 n.25. He also linked them to terminology introduced by Thomas Street, calling suits under Rule 23(a)(1) "true," suits under Rule 23(a)(3) “spurious,” and suits under Rule 23(a)(2) “hybrid.” Id. 310 n.25; James W. Moore \& Marcus Cohn, Federal Class Actions_Jurisdiction and Effect of Judgment, 32 ILL. L. REV. 555, 555 (1938). Robert Bone has argued, however, that Moore's "tripartite scheme fit nineteenth and early twentieth century representative suit categories poorly.” Robert G. Bone, Book Review, Personal and Impersonal Litigative Forms: Reconceiving the History of Adjudicative Representation 70 B.U. L. REV. 213, 288-89 (1990) (reviewing YEAZELL, supra note 108). These three categories were abolished in 1966, when Rule 23(a) took its modern form. See Notes of Advisory Committee on 1966 Amendments (stating that the Rule 23(a) classification “proved obscure and uncertain”); see also Charles Alan Wright, Federal Rules Decisions, 47 F.R.D. 169, 175-77 (1970) (criticizing the 1937 classification).
}

The Federal Rules of Civil Procedure also covered derivative suits. The Supreme Court first recognized the right of shareholders to sue derivatively in Dodge v. Woolsey, 59 U.S. (18 How.) 331 (1856). Beginning in 1887, the Court established certain limitations on derivative suits, such as the requirement that they plaintiff allege that the directors have acted unwisely or in bad faith. Hawes v. Oakland, 104 U.S. 450 (1882); see John C. Coffee \& Donald E. Schwartz, The Survival of the Derivative Suit: An Evaluation and a Proposal for Legislative Reform, 81 COLUM. L. REV. 261, 265-68 (1981). But the number of suits grew so substantially in the second half of the nineteenth and first half of the twentieth centuries that in 1949 the Court could term them the "chief regulator of corporate management." Cohen v. Beneficial Indus. Loan Corp., 337 U.S. 541, 548 (1949). Rule 23(b) of the Federal Rules of Civil Procedure of 1938 codified some of the restrictions on derivative suits, in particular the demand requirement. FED. R. CIV. PRO. 23(b) (1938) ("The complaint shall also set forth with particularity the efforts of the plaintiff to. secure from the managing directors or trustees and, if necessary, from the shareholders such action as he desires, and the reasons for his failure to obtain such action or the reasons for not making such effort. Nevertheless, as the number of strike suits grew, states began to impose more restrictions on derivative actions, such as requiring security for expenses. See, e.g., George D. Hornstein, New Aspects of Stockholders' Derivative Suits, 47 Colum. L. REV. 1, 4 (1947). Despite this, derivative suits survived and flourished. See, e.g., Coffee \& Schwartz, at 261; Daniel J. Dykstra, The Revival of the Derivative Suit, 116 U. PA. L. REV. 74 
change in representative litigation over this period was in the interest groups that used the doctrines, rather than in the rules themselves. During the 20th century, representative litigation transformed from an "oddity” on the fringe of American jurisprudence to a regular, powerful tool for certain groups of litigants. ${ }^{139}$ A number of constituencies began to employ the representative action with effect in a range of substantive areas, including mass tort, civil rights, and corporate litigation. ${ }^{140}$ The legal services industry responded in turn, leading to competition (or perhaps cooperation) among counsel to represent large, and often lucrative, classes. ${ }^{141}$ And that behavior has culminated in the inefficiencies and perverse incentives reviewed in Section I above.

\section{Summary}

The 20th century saw a double-movement regarding the allocation of actions among the states. International Shoe and its progeny expanded courts’ reach by transforming jurisdictional analysis from a formalistic examination of static boundaries to a case-by-case inquiry into the facts of a defendant's connections with a forum. Relatedly, the courts ended the use of the internal affairs doctrine as a jurisdictional bar, retaining it solely for the purpose of determining the law applicable to a dispute.

(1967). In 1966, Rule 23(b) was made its own separate provision-Rule 23.1—and was amended so that the plaintiff must "fairly and adequately represent the interests of shareholders.” FED. R. CIV. PRO. 23.1; see id. (Notes of Advisory Committee on 1966 Amendments).

139 Compare YEAZELL, supra note 75, at 224 ("[G]roup litigation entered the twentieth century as an oddity . . ..”), with id. at 237 (noting that the amendments to the Federal Rules of Civil Procedure in 1966 led to a "flowering" of class actions). See also 7A WRIGHT \& MILLER, supra note 101, § 1751 ("It now is apparent that the increasing complexity and urbanization of modern American society has magnified tremendously the importance of the class action as a procedural device for resolving disputes affecting numerous people.”).

${ }^{140}$ See, e.g., YEAZELL, supra note 75, at 243-44 (importance of class actions to consumer and environmental movement); id. at 240-43 (civil rights movement). See supra note 138 (growth of stockholders' derivative suits).

${ }^{141}$ See, e.g., Bruce H. Kobayashi \& Larry E. Ribstein, Class Action Lawyers as Lawmakers, 46 ARIZ. L. REV. 733, 772 (2004) (discussing competition among lawyers to assemble plaintiff groups with a large financial interest in litigation under the PSLRA). For an opposing view-that plaintiffs' firms tend to collude, rather than compete, with each other-see Susan P. Koniak \& George M. Cohen, Under Cloak of Settlement, 82 VA. L. REV. 1051, 1089-1102 (1996). 
Although a departure from Pennoyer's formalism, the 20th century approach retained a territorial basis. The minimum contacts analysis for determining personal jurisdiction still looks through the old lens of geography, focusing on a defendant's physical connections to a forum. In other words, although physical boundaries no longer were outcome determinative, geography remained important.

What the modern approach abandoned, however, is the link between the choice of forum and choice of law. Although it is possible, and perhaps even likely, that the minimum contacts analysis and the most substantial relationship rules will result in a single jurisdiction being selected in both the choice of forum and choice of law analysis, it is equally possible that one state will be deemed an appropriate forum while another state's laws are chosen to apply. Even as the choice of forum and choice of law approach have evolved in parallel tracks, resulting in conceptual consistency between them, their flexible approaches can produce outcomes that are, in practice, decoupled.

\section{Forum Non Conveniens and the First-Filed Rule: Ineffective Counterbalances to Expanding Jurisdictional Reach}

The expansion of jurisdiction discussed in Section II was coupled with the countervailing development of a discretionary doctrine that allowed the courts to refuse to hear a case. ${ }^{142}$ Described occasionally as a "safety valve," ${ }^{143}$ the doctrine of forum non conveniens gave the courts a basis upon which to decline to exercise jurisdiction. Complementing forum non conveniens as a means for allocating jurisdiction particularly in parallel litigation scenarios was the increased use of the first-filed rule, the modern

\footnotetext{
${ }^{142}$ See Stein, supra note 117, at 801-03 (noting that the forum non conveniens doctrine was adopted in response to "the expansion of personal jurisdiction and the demise of Pennoyer v. Neff').

${ }^{143}$ See Earl M. Maltz, Choice of Forum and Choice of Law in the Federal Courts, 79 KY. L.J. 231, 250 (1991) (applying the term "safety valve" to forum non conveniens).
} 
iteration of the abatement doctrine described below. Therefore, although the general

movement in the 20th century was to expand courts' ability to exercise their jurisdiction, rules were also developed to avoid situations where adjudicating an action would place a heavy burden on a defendant (and to relieve pressure on courts’ dockets). ${ }^{144}$

In practice the first-filed rule and forum non conveniens are often used in tandem. ${ }^{145}$ The two rules' evidentiary thresholds have an important difference, however: defendants face a lower hurdle in seeking to stay a second-filed lawsuit, where “discretion should be freely exercised in favor of the stay" if the elements supporting the movant's request are present, ${ }^{146}$ compared to the burden required to dismiss an action based on the doctrine of forum non conveniens, ${ }^{147}$ And this may make perfect sense in

\footnotetext{
${ }^{144}$ Tools other than the forum non conveniens doctrine and the first filed rule have tentatively emerged as means to address parallel suits. Doctrines such as federal abstention doctrine or anti-suit injunctions also provide a basis for a refusal to exercise jurisdiction, but those doctrines are largely similar to forum non conveniens for our purposes, and we therefore do not discuss them in depth here. Likewise, we postpone discussing certain "work-arounds" that have recently surfaced—e.g., forum selection charter or bylaw provisions and "one-forum," or "Savitt" motions-to the treatment of our policy recommendations in Part V below. For the origin of the term "Savitt" motion, see Mot. To Proceed in One Jurisdiction, In re Wyeth S’holders Litig., C.A. No. 4329-VCN (Mar. 25, 2009).

${ }^{145}$ See Silverstein v. Warner Commc’ns, Inc., No. 11285, 1991 WL 12835 (Del. Ch. Feb. 5, 1991); Jim Walter Corp. v. Allen, No. 10974, 1990 WL 3899, at *472-73 (Del. Ch. Jan. 12, 1990).

${ }^{146}$ Ingres Corp. v. CA, Inc., 8 A.3d 1143, 1145 (Del. 2010) ("Delaware courts should exercise discretion in favor of a stay where a prior action, involving the same parties and issues, is pending elsewhere in a court capable of doing prompt and complete justice.”); see also Sensient Colors Inc. v. Allstate Ins. Co., 939 A.2d 767, 774 (N.J. 2008) ("Under the first-filed rule, a New Jersey state court ordinarily will stay or dismiss a civil action in deference to an already pending, substantially similar lawsuit in another state, unless compelling reasons dictate that it retain jurisdiction.”) (citation omitted); Perry v. Del Rio, 66 S.W.3d 239, 252 (Tex. 2001) ("It is not unusual for parties with a choice of forums to prefer one over another, and when more than one party can sue on the same subject matter, they may choose difference courts. As a rule, when cases involving the same subject matter are brought in different courts, the court with the first-filed case has dominant jurisdiction and should proceed, and the other cases should abate.”) (citations omitted); White Light Productions, Inc. v. On the Scene Prods., Inc., 231 A.D.2d 90, 96-97 (N.Y. App. Div. 1997) ("As a matter of New York policy, the rule has been stated that 'proceedings begun in another State should not be interfered with unless there is some necessity clearly shown. Generally the court which has first taken jurisdiction is the one in which the matter should be determined and it is a violation of the rules of comity to interfere."”) (citations omitted).

${ }^{147}$ Under Delaware law, courts will only dismiss a case on forum non conveniens grounds if the factors "overwhelmingly" favor adjudicating the case in the alternative forum. See Berger v. Intelident Solutions, Inc., 906 A.2d 134, 135 (Del. 2006); Candlewood Timber Group, LLC v. Pan Am. Energy, LLC, 859 A.2d 989, 998-99 (Del. 2004); Warburg Pincus Ventures, L.P. v. Schrapper, 774 A.2d 264, 267 (Del. 2001). That burden decreases if only a stay of the proceedings is sought. See HFTP Invs., LLC v. Ariad Pharms., Inc., 752 A.2d 115, 121 (Del. Ch. 1999). For cases in other jurisdictions, see Durkin v. Intevac, Inc., 782
} 
the garden variety tort case, where the court should respect the plaintiff's forum choice ${ }^{148}$ and not permit the defendant to strategically file parallel litigation to defeat it. ${ }^{149}$ But in shareholder class and derivative actions the need to respect the plaintiffs' (attorney’s) choice of forum may take a backseat to other issues, such as what is best for the shareholders as a class. ${ }^{150}$ A particularly egregious example of filing suit in a foreign jurisdiction with a lack or regard to the class as a whole is when a plaintiffs' attorney filed in a jurisdiction where they could not even get class certification. ${ }^{151}$ Which

A.2d 103, 111 (Conn. 2001) ("Accordingly, the trial court, in exercising its structured discretion, should place its thumb firmly on the [plaintiffs'] side of the scale, as a representation of the strong presumption in favor of the [plaintiffs'] chosen forum, before attempting to balance the private and public interest factors relevant to a forum non conveniens motion.") (citations omitted); Ex parte Preston Hood Chevrolet, Inc., 638 So. 2d 842, 845 (Ala. 1994) ("The court will weigh the relative advantages and burdens associated with litigating in the plaintiff's choice of forum. Nevertheless, 'unless the balance is strongly in favor of the defendant, the plaintiff's choice of forum should rarely be disturbed."') (citation omitted); and Torres v. Walsh, 456 N.E.2d 601, 607 (Ill. 1983) ("We also caution our trial courts that unless those [forum non conveniens] factors strongly favor the defendant, then the plaintiff should be allowed to exercise his choice in deciding in what forum to bring the case when venue is proper.”).

${ }^{148}$ Supra note 7.

${ }^{149}$ See, e.g., McWane Cast Iron Pipe Corp. v. McDowell-Wellman Eng'g Co., 263 A.2d 281, 283 (Del. 1970) ("[A] defendant should not be permitted to defeat the plaintiff's choice of forum in a pending suit by commencing litigation involving the same cause of action in another jurisdiction of its own choosing ... [this is] impelled by considerations of comity and the necessities of an orderly and efficient administration of justice”); CTC Demolition Co. v. GMH AETC Mgmt./Dev. LLC, 34 A.3d 1258, 1261 (N.J. Super. App. Div. 2012) ("The first-filed rule, as noted at the outset, generally requires that a court with jurisdiction over a matter should defer to the court that first acquired jurisdiction over the dispute. As explained by our Supreme Court, '[i]f we are to have harmonious relations with our sister states, absent extenuating circumstances sufficient to qualify as special equities, comity and common sense counsel that a New Jersey court should not interfere with a similar, earlier-filed case in another jurisdiction that is capable of affording adequate relief and doing complete justice.”') (citations omitted).

${ }^{150}$ La. Mun. Police Emps.’ Ret. Sys. v. Medco Health Solutions, Inc., 46 A.3d 313, 337 (Del. Ch. 2012) ('Because specialized plaintiffs' firms ultimately receive compensation from awards of attorneys' fees, their interests can diverge from the class or entity they represent. Interests diverge routinely during the initial period following an event that could provide a basis for filing a case.”) (citing Biondi v. Scrushy, 820 A.2d 1148, 1158-59 (Del. Ch. 2003), aff'd sub nom. In re HealthSouth Corp. S'holders Litig., 847 A.2d 1121 (Del. 2004) ("The application of the McWane doctrine to representative actions-i.e., class and derivative actions-is troublesome. In that context, the McWane doctrine is both most useful and most difficult to apply. Representative actions present the greatest chance for identical claims to be presented to multiple courts at the same time. Hence, there is utility to a legal rule of decision that promotes comity and judicial economy by reducing the likelihood for duplicative effort and unseemly wrestling over which forum should take hold of a matter. At the same time, representative actions pose certain dangers-in particular, the potential divergence in the best interests of the plaintiffs' attorneys and the plaintiffs they are purporting to represent - that are not addressed, and indeed may be exacerbated, by a legal rule that places determinative weight on which complaint was filed first.”)).

${ }^{151}$ See, e.g., Tr. of Oral Arg., Continuum Capital v. Nolan, C.A. No. 5687-VCL, at *4-5 (Del. Ch. Aug. 10, 2010) (discussing the problems with filing on behalf of shareholders in Virginia where "there is case law 
illustrates that even the first filed rule, with its lower burden, does not adequately deal with the choice of forum problem in representative litigation. Thus, neither the first filed rule nor the doctrine of forum non conveniens responds to the multi-forum litigation problem in a principled manner that promotes stable and cohesive development of the law or protects parties’ legitimate expectations.

\section{A. Forum Non Conveniens as a Basis for Declining to Exercise Jurisdiction}

As the doctrine of personal jurisdiction was expanding, the countervailing rule of forum non conveniens was also being developed. ${ }^{152}$ With little precedent before the 1930s, ${ }^{153}$ the Supreme Court embraced the doctrine of forum non conveniens in its Gulf Oil Corp. v. Gilbert decision, which held that a court could, in its discretion, decline to exercise jurisdiction in situations where both public and private interests point to adjudicating a dispute in an alternative forum. ${ }^{154}$ Echoing the Gulf Oil decision, the

from Virginia appellate courts that talk about how you cannot certify a class in an action that seeks money damages”).

${ }^{152}$ Stephen B. Burbank, Jurisdictional Conflict and Jurisdictional Equilibration: Paths to a Via Media?, 26 HOUSTON J. INT’L L. 385, 393 (2003) (“However ancient its lineage, forum non conveniens as a general tool of jurisdictional equilibration dates to the 1940s, to the very period, that is, when the Supreme Court was empowering states to broaden their jurisdictional reach.”).

${ }^{153}$ See Stein, supra note 117, at 811-12 (noting that the forum non conveniens concept was first articulated in 1929 in a law review article and there are almost no references to the doctrine before that article's publication) (citing Paxton Blair, The Doctrine of Forum Non Conveniens in Anglo-American Law, 29 Colum. L. ReV. 1 (1929)).

${ }^{154} 330$ U.S. 501, 507-09 (1947). In 1992, thirty-two states and the District of Columbia had recognized the doctrine of forum non conveniens "through statute, common law, or procedural methods." Christopher Speer, The Continued Use of Forum Non Conveniens: Is It Justified?, 58 J. AIR L. \& CoM. 845, 846 n.2 (1993). Forum non conveniens was a controversial issue in other states. See Paula K. Speck, Access to State Courts in Transnational Personal Injury Cases: Forum Non Conveniens and Antisuit Injunctions, 68 TEX. L. REV. 937, 949-51 (1991) ("Four ... states have given ... equivocal indications of following the federal doctrine. Still four other states have adopted more limited versions of forum non conveniens .... . In five states the existence of a forum non conveniens doctrine is a completely open question. Courts in Montana and West Virginia have rejected forum non conveniens in FELA cases, otherwise leaving the doctrine's existence an open question. Louisiana law precludes forum non conveniens dismissal except in a narrow range of situations .... And at this writing the decisions in Georgia and Texas seem to reject the doctrine altogether.”). But, by 2002, fifteen states and the District of Columbia had adopted forum non conveniens through statute or rules of procedure and thirty-one states had adopted forum non conveniens through case law. Michael J. Jacobs, Georgia on the Non-Resident Plaintiff's Mind: Why the General Assembly Should Enact Statutory Forum Non Conveniens, 36 GA. L. REV. 1109, 1110 \& n.9 (2002). 
Second Restatement states that "[a] state will not exercise jurisdiction if it is a seriously inconvenient forum for the trial of the action provided that a more appropriate forum is available to the plaintiff.” ${ }^{255}$

To determine whether a forum is "seriously inconvenient," the Second Restatement recommends consideration of a number of factors. First, it identifies the "two most important factors" for the court to consider, namely the fact that "since it is for the plaintiff to choose the place of suit, his choice of forum should not be disturbed except for weighty reasons," and that the action should not be dismissed unless an appropriate alternative exists. ${ }^{156}$ Those factors raise a high hurdle for a movant to overcome. ${ }^{157}$ Second, the Second Restatement lists the following "private" interests to be considered: access to proof; availability of compulsory process; possibility of viewing the premises; the enforceability of any resulting judgment; and "all other practical problems that make trial of a case easy, expeditious and inexpensive." ${ }^{158}$ Finally, the Second Restatement provides a number of "public" interests that factor into the analysis: inefficiencies arise if litigation is "piled up in congested centers instead of being handled

\footnotetext{
155 RESTATEMENT (SECOND) OF CONFLICT OF LAWS § 84 (1971).

${ }^{156} I d$. cmt. c.

${ }^{157}$ See Thomson v. Palmieri, 355 F.2d 64, 66 (2d Cir. 1966) (noting that "the central question [in a motion to dismiss under forum non conveniens] is one of convenience, and we should respect plaintiff's choice of forum as long as no harassment is intended”); All States Freight v. Modarelli, 196 F.2d 1010, 1011 (3d Cir. 1952) ("[The forum non conveniens] doctrine involves the dismissal of a case because the forum chosen by the plaintiff is so completely inappropriate and inconvenient that it is better to stop the litigation in the place where brought and let it start all over again somewhere else. It is quite naturally subject to careful limitation for it not only denies the plaintiff the generally accorded privilege of bringing an action where he chooses, but makes it possible for him to lose out completely, through the running of the statute of limitations in the forum finally deemed appropriate.”); Mobil Tankers Co. v. Mene Grande Oil Co., 363 F.2d 611, 613-14 (3d Cir. 1966) (noting that "unless 'the balance is strongly in favor of the (respondent), (the libellant's) choice of forum should rarely be disturbed'” and reversing lower court's dismissal under forum non conveniens where action was brought in New York but governed by Venezuelan law, because dismissal "would relegate the libellants to a foreign forum in which the procedural remedies are far less conducive to the fair administration of justice than those available under our admiralty rules") (quoting Gulf Oil Corp. v. Gilbert, 330 U.S. 501, 508 (1947)).

${ }^{158}$ Gulf Oil Corp., 330 U.S. at 508.
} 
at its origins;" jury duty should not be imposed on members of a community unrelated to the litigation; and a court should not have to "untangle problems in conflict of laws, and in law foreign to itself." ${ }^{159}$ Weighing these factors is a matter of discretion for the judge, and depends upon the facts of any given case. ${ }^{160}$

Forum non conveniens is a limited solution to the modern multi-forum litigation problem because, just like contemporary minimum contacts analysis, its factors focus upon a defendant's geographic connections to a state. Inconvenience to a defendant is understood in terms of the physical costs of a court proceeding — whether evidence will be readily available, whether the premises are close enough for inspection, whether witnesses can be compelled to testify, whether a trial will be "easy, expeditious, and inexpensive," etc. The Second Restatement's geographic focus is also evidenced in its

\footnotetext{
${ }^{159} \mathrm{Id}$.

${ }^{160}$ Restatement (SECOND) OF CONFLiCT OF LAWs $\S 84 \mathrm{cmt}$. b (1971). The federal abstention doctrines often serve a similar function to forum non conveniens, although the doctrines' origins and analysis differ in important respects. Quackenbush v. Allstate Ins. Co., 517 U.S. 706, 722-23 (1996) ("To be sure, the abstention doctrines and the doctrine of forum non conveniens proceed from a similar premise: In rare circumstances, federal courts can relinquish their jurisdiction in favor of another forum. But our abstention doctrine is of a distinct historical pedigree, and the traditional considerations behind dismissal for forum non conveniens differ markedly from those informing the decision to abstain.”). The U.S. Supreme Court's first articulation of the doctrine of abstention was in Pullman, which stands for the proposition that, if there is an unsettled question of state law, the resolution of which may make consideration of a federal constitutional question unnecessary, then the federal court should abstain from deciding the case until the state court has resolved the state question. R.R. Comm'n v. Pullman Co., 312 U.S. 496, 500-01 (1941). Later, the court articulated a second type of abstention in Burford, where the court established that there may be circumstances where a court should decline to hear a case where doing so would lead to "[d]elay, misunderstanding of local law, and needless federal conflict with State policy.” Burford v. Sun Oil Co., 319 U.S. 315, 327 (1943); see also Younger v. Harris, 401 U.S. 37 (1971). In each of these variations, the overarching concerns animating these abstention doctrines are rooted in federalism. Quackenbush, 517 U.S. at 723 ("Federal courts abstain out of deference to the paramount interests of another sovereign, and the concern is with principles of comity and federalism.").

But, there is another type of abstention that more closely mimics the forum non conveniens analysis. In its 1976 decision in Colorado River, the Supreme Court held that, for reasons of judicial efficiency, there are situations where a federal court should defer to a concurrent state court proceeding. Colorado River Water Conservation Dist. v. United States, 424 U.S. 800 (1976). Noting that the "general principle [in the federal courts] is to avoid duplicative litigation," the court in Colorado River stated that it considered the following factors when deciding whether to abstain from exercising jurisdiction on efficiency grounds: (1) the avoidance of piecemeal litigation; (2) the order in which jurisdiction was obtained, namely the absence of any proceedings in the federal trial court, other than filing a complaint; (3) the broad implication of rights based in state law; (4) the convenience of the federal forum to the parties; and (5) the defendant's participation in state court proceedings in pre-existing, related litigations. Id. at 819-20.
} 
comments, which suggest that the geographic locations of the incident leading to the dispute and of the defendant's domicile are presumed to be suitable forums. ${ }^{161}$ Concern about consistent application of law is mentioned as only one of a number of factors. Forum non conveniens analysis is driven more by process concerns-the availability of witnesses, for example_-viewed through a geography-focused lens, than by an interest in promoting stable precedent and vindicating parties’ established expectations. ${ }^{162}$

\section{B. The So Called "First-Filed Rule" as an Additional Basis for Determining Priority Among Parallel Actions}

As noted above, the first filed rule is often a complement to forum non

conveniens. In addition to placing a lower burden of persuasion on a person seeking a

stay, the so called first-filed rule has the advantage over forum non conveniens of not

being tied down directly to notions of parties’ geographic connections to a forum. ${ }^{163}$ In

its contemporary formulation, the first-filed rule provides that, when parallel litigation

has been initiated in separate courts, the suit that commences first has priority, and

\footnotetext{
${ }^{161}$ RESTATEMENT (SECOND) OF CONFLICT OF LAWS $§ 84 \mathrm{cmt} . \mathrm{f}$ (1971).

${ }^{162}$ The Supreme Court has freely admitted that forum non conveniens doctrine is unstable and unpredictable. Am. Dredging Co. v. Miller, 510 U.S. 443, 455 (1994) ("The discretionary nature of the doctrine, combined with the multifariousness of the factors relevant to its application . . . make uniformity and predictability of outcome almost impossible.”). Even when the Court first adopted the forum non conveniens doctrine in Gulf Oil Corp. v. Gilbert, the Court laid out a list of factors, relating to both the "private interest" of the litigants and the "public interest" of society and the judicial process, that a district court could consider when determining whether to dismiss a suit on forum non conveniens grounds-but admitted that "the combination and weight of factors requisite to given results are difficult to forecast or state.” 330 U.S. 501, 508 (1947). One author complained in 1985 that courts' decisions are inconsistent, dubbing them a "quilt of ad hoc, capricious, and inconsistent" rulings. Stein, supra note 117, at 785. Courts have tended simply to recite the Gulf Oil factors and then conclude that the factors' application favors retention or dismissal, and decisions are virtually immune from appellate review. Id. at 831-32. If anything, "forum non conveniens dismissal standards have become steadily less predictable" in the last thirty years. Elizabeth T. Lear, Congress, the Federal Courts, and Forum Non Conveniens: Friction on the Frontier of the Inherent Power, 91 IOWA L. REv. 1147, 1150 (2006).

${ }^{163}$ In short the first-filed rule provides just what its name implies: that second-filed actions should be stayed or dismissed in deference to the first-filed action. See infra notes 168 to 172 and accompanying text. But application of the first-filed rule can often take on aspects of forum non conveniens analysis. See WOLFE \& PITTENGER, supra note 42, § 5.01 ("[T] of the same factors applied under the traditional forum non conveniens analysis.”).
} 
subsequent actions are to be stayed or dismissed in deference to it. ${ }^{164}$ At its core, the first-filed rule is based upon respect for a plaintiff's choice of forum and upon considerations of comity and the orderly administration of justice. ${ }^{165}$ Key motivations behind the rule include the avoidance of "wasteful duplication of time, effort, and expense,” the "possibility of inconsistent and conflicting rulings and judgments,” and preventing "an unseemly race by each party to trial and judgment in the forum of its choice."166

The origins of the first filed rule can be traced both to nineteenth century federal decisions that gave preference to first-filed cases in situations where two courts had

\footnotetext{
${ }^{164}$ As a general matter, federal courts follow a "first-filed" rule. 15 WRIGHT \& MILLER, supra note 101, § 3854 ("[W]hen two courts have concurrent jurisdiction over a dispute involving the same parties and issues, as a general proposition the forum in which the first-filed action is lodged has priority."); see, e.g., Orthmann v. Apple River Campground, Inc., 765 F.2d 119, 121 (8th Cir. 1985) (citing Pacesetter Sys., Inc. v. Medtronic, Inc., 678 F.2d 93, 94-95 (9th Cir. 1982); Merrill Lynch, Pierce, Fenner \& Smith v. Haydu, 675 F.2d 1169, 1174 (11th Cir. 1982)). State courts also follow a "first-filed" rule, although, like the federal rule, the doctrine is discretionary. See, e.g., Leadford v. Leadford, 8 Cal. Rptr. 2d 9, 12 (Ct. App. 1992) ("[I]n many cases, considerations of comity and the prevention of multiple and vexatious litigation will most often militate in favor of stay [in favor of earlier filed action in different state].”); McWane Cast Iron Pipe Corp. v. McDowell-Wellman Eng'g Co., 263 A.2d 281, 283 (Del. 1970) (stating that a court's discretion to stay an action "should be exercised freely in favor of the stay when there is a prior action pending elsewhere, in a court capable of doing prompt and complete justice, involving the same parties and the same issues”); Leslie Fay Retail Outlets, Inc. v. Gallery Mfg., Corp., 653 So.2d 1106, 1107 (Fla. Dist. Ct. App. 1995) ("Principles of comity between sovereigns suggest that a court of one state should stay a proceeding pending before it on grounds that a prior filed case involving substantially the same subject matter and parties is pending in another state's courts.”); Edward Rose Bldg. Co. v. Cascade Lumber Co., 621 N.W.2d 193, 195-96 (Iowa 2001) ("A court may defer to the courts of another state where there is a pending proceeding involving the same subject matter and parties ....”); Yancoskie v. Del. River Port Auth., 395 A.2d 192 (N.J. 1978) ("[T]he general rule [is] that the court which first acquires jurisdiction has precedence in the absence of special equities.”); White Light Prods., Inc. v. On the Scene Prods., Inc., 660 N.Y.S.2d 568, 572 (App. Div. 1997) ("Generally the court which has first taken jurisdiction is the one in which the matter should be determined and it is a violation of the rules of comity to interfere.") (citation omitted); Space Master Int’l, Inc. v. Porta-Kamp Mfg. Co., 794 S.W.2d 944, 946 (Tex. Ct. App. 1990) (“As a matter of comity ... it is the custom for [a] court in which the later action is instituted to stay proceedings therein until the prior action is determined ....”); see also 21 CORPUS JURIS SECUNDUM §308 (updated ed. 2012) ("The mere pendency of a prior parallel suit in one state cannot be pleaded in abatement or in bar to a subsequent suit in another state or country, but as a matter of comity, the court of one state may stay a proceeding pending before it on the ground that a case involving the same subject matter and the same parties is pending in a court of another state ....”).

${ }^{165}$ E.g., McWane, 263 A.2d at 283; Cascade Lumber Co., 621 N.W.2d at 196; White Light Prods., 660 N.Y.S.2d 568 at 572-73.

${ }^{166}$ McWane, 263 A.2d at 283.
} 
concurrent jurisdiction ${ }^{167}$ and to the common law doctrine of abatement. ${ }^{168}$ It appears

that the rule was originally developed outside of the representative litigation context as a

mechanism for staying or dismissing a second filed suit between the same two parties. ${ }^{169}$

As such, the first-filed rule was a tool for preventing a defendant from initiating "reactive”

\footnotetext{
${ }^{167}$ The Supreme Court applied the first-filed rule as early as 1824, when it decided that "[i]n all cases of concurrent jurisdiction, the Court which first has possession of the subject must decide it" in a situation where a party to a property dispute sought equitable relief in a court of chancery after receiving an adverse ruling from a court of law. Smith v. McIver, 22 U.S. (9 Wheat.) 532, 536 (1824); see also Rickey Land \& Cattle Co. v. Miller \& Lux, 218 U.S. 258, 262 (1910) (affirming a California state court's decision to enjoin proceedings in deference to a first-filed action in Nevada, reasoning that "there was concurrent jurisdiction in the two courts, and that the substantive issues in the Nevada and California suits were so far the same that the court first seised should proceed to the determination without interference, on the principles now well settled as between the courts of the United States and of the states”); Crosley Corp. v. Hazeltine Corp., 122 F.2d 925, 930 (3d Cir. 1941), cert. denied, 315 U.S. 813 (1942) (citing McIver and stating that, when "two actions are pending in courts of equal dignity within the judicial system of a single sovereignty," the party who first files suit should be able to enjoin "subsequent litigation over the same subject matter"). Much of the federal law involving the first-filed rule has arisen out of suits for declaratory judgments, which are often brought in the patent infringement context. See Crosley, 122 F.2d at 930 (noting that the first-filed rule applies "with especial force to patent suits . . . brought under the Declaratory Judgment Act”); see also Kerotest Mfg. Co. v. C-O-Two Fire Equip. Co., 342 U.S. 180, 185 (1952) (patent infringement suit discussing first-filed rule); see generally Michael A. Cicero, First-To-File And Choice-Of-Forum Roots Run Too Deep for Micron To Curb Most Races to the Courthouse, 90 J. PAT. \& TRADEMARK OFF. SOC'Y 547, 550-57 (2008) (discussing the evolution of the first-filed rule in the patent infringement context).

${ }^{168}$ State courts tend to base their first-filed rules on the doctrine of abatement and on general principles of comity rather than on the line of federal authority that evolved from Smith, as described in the previous footnote. See, e.g., McWane, 263 A.2d at 283 (stating that a court's discretion to stay an action "should be exercised freely in favor of the stay when there is a prior action pending elsewhere, in a court capable of doing prompt and complete justice, involving the same parties and the same issues”); O'Loughlin v. O’Loughlin, 78 A.2d 64, 68 (N.J. 1951) (“Considerations of comity forbid interference with the prosecution of a proceeding in a foreign jurisdiction capable of affording adequate relief and doing complete justice, unless there be a special equity sufficient in conscience to stay the hand of the defendant .... The rule of comity is grounded in the policy of avoiding conflicts of jurisdiction, unless upon strong grounds, and the general principle that the court which first acquires jurisdiction of the issue has precedence.”).

Although the common law doctrine of abatement closely resembles the first-filed rule articulated by the Supreme Court in McIver, neither the abatement case law nor McIver and its progeny appear to invoke or reference the other in the discussion of their respective doctrines. Abatement, in its general sense, refers to "a termination of the proceedings of an action by reason of some formal defect or misnomer." 1 C.J.S. Abatement and Revival § 1; see also BLACK’s LAW DICTIONARY (9th ed. 2009) (defining “abatement” in relevant part to mean "[t]he suspension or defeat of a pending action for a reason unrelated to the merits of the claim"). One ground for an abatement defense is "that there is a separate, identical lawsuit pending." Hyman v. City of Gastonia, 466 F.3d 284, 287 (4th Cir. 2006) (citing 1 Am.Jur.2d Abatement, Survival, and Revival §§ 1-44); see also Allan D. Vestal, Repetitive Litigation, 45 IowA L. REV. 525, 528 (1960) ("Under the common law the pendency of an action in a court of general jurisdiction involving the same parties and the same cause of action was grounds for a plea of abatement in a second suit brought on the same cause of action.”).

${ }^{169}$ See, e.g., Biondi v. Scrushy, 820 A.2d 1148, 1159 n.21 (Del. Ch. 2003) (discussing the application of Delaware's first-filed rule to representative suits, and stating that, "in this regard, it is noteworthy that McWane itself did not involve a representative action”).
} 
litigation that would make an end-run around a plaintiff by filing a subsequent action in a forum more to its liking. ${ }^{170}$

As originally articulated, the doctrine of abatement (and its first-filed component)

generally applied only to competing actions within the same state, and the doctrine did not apply to identical suits pending in multiple jurisdictions. ${ }^{171}$ Over the course of the

${ }^{170}$ See, e.g., Thompson v. FitzGerald, 198 A. 58, 62 (Pa. 1938) (“'It is a doctrine of law too long established to require a citation of authorities, that, where a court has jurisdiction, it has a right to decide every question which occurs in the cause, and ... where the jurisdiction of a court, and the right of a plaintiff to prosecute his suit in it, have once attached, that right cannot be arrested or taken away by proceedings in another court. These rules have their foundation, not merely in comity, but on necessity. For if one may enjoin, the other may retort by injunction, and thus the parties be without remedy; being liable to a process for contempt in one, if they dare to proceed in the other."' (quoting Peck v. Jenness, 48 U.S. (7 How.) 612, 624 (1849)); see also McWane, 263 A.2d at 283 (“[A] defendant should not be permitted to defeat the plaintiff's choice of forum in a pending suit by commencing litigation involving the same cause of action in another jurisdiction of its own choosing ....”).

Sometimes, courts would not simply enjoin "reactive" litigation, but would prevent a party from suing in another forum even when that party was unaware of the pending suit against it, in order to prevent duplicative litigation. In Connecticut Mutual Life Insurance Co. v. Merritt-Chapman \& Scott Corp., the court enjoined the defendant from prosecuting a suit in New York, on the ground that the plaintiff had filed suit in Delaware, one day before the defendant filed. 163 A. 646 (Del. Ch. 1932). The court held that it was irrelevant that the defendant had received the plaintiff's subpoena after the plaintiff had received the defendant's subpoena. Id. at 647-48. On the other hand, a court would only issue an injunction against a later filed action if the earlier-filed action could definitively resolve the case. E.g., Peyton v. William C. Peyton Corp., 187 A. 849, 852 (Del. Ch. 1936) (“[W]here the courts of the forum in which the first suit was inaugurated are, by reason of the absence of jurisdiction over all the parties in interest, powerless to render a decree that finally and completely concludes the matter in controversy, an injunction ought not to issue against the bringing of suits elsewhere if the effect of such injunction would be to interfere with an attempt by the defendant to bring the matter to a head before some other court where all the parties could be served and their respective claims conclusively determined.”). Courts would also decline to issue injunctions against later-filed actions if they could not obtain jurisdiction over the parties to be enjoined. E.g., Smith v. Biggs Boiler Works Co., 85 A.2d 365, 367 (Del. Ch. 1951).

${ }^{171}$ Historically, for the purpose of determining whether abatement was proper, there was a significant doctrinal distinction between in personam actions and in rem or quasi in rem. When the competing actions at issue were in personam, the traditional rule was that the first suit would only abate the second suit when the jurisdiction between the two courts was concurrent - that is, within the same state or jurisdictional territory. See Mut. Life Ins. Co. of New York v. Brune’s Assignee, 96 U.S. (6 Otto) 588, 592 (1877) (“At law, the pendency of a former action between the same parties for the same cause is pleadable in abatement to a second action, because the latter is regarded as vexatious. But the former action must be in a domestic court; that is, in a court of the State in which the second action has been brought.”); Lynch v. Hartford Fire Ins. Co., 17 F. 627, 628-29 (D.N.H. 1883) ("The general rule is that a plea of lis alibi pendens is not good when the litigation is in a court of foreign jurisdiction.”); Colson v. Pelgram, 259 N.Y. 370, 375 (1932) (“It is also the general rule that, where separate actions have been instituted between the same parties in reference to the same subject-matter in courts having concurrent jurisdiction, the court which first obtains jurisdiction with adequate power to administer full justice should continue to exercise it.”); Smith v. Lathrop, $44 \mathrm{~Pa}$. 326, 330-31 (1863) (holding that, although full faith and credit would be given to a foreign court's judgment, the mere pendency of a suit in a foreign court could not bar proceedings in a different sovereign's courts); 1 AM. JUR. 2D Abatement, Survival, and Revival § 6; see also CHARLES D. DRAKE, A TREATISE ON THE LAW OF SUITS BY ATTACHMENT IN THE UNITED STATES § 701 (3d ed. 1866) 
twentieth century, this limitation as to interstate disputes disappeared, ${ }^{172}$ and the first-

\author{
filed rule became broadly applicable to a wide variety of actions. As representative
}

(summarizing Massachusetts, Alabama, Louisiana, Indiana, and California attachment cases as supporting the proposition that stays but not dismissals were appropriate, reasoning that jurisdictional conflicts "are avoided by considering [the parallel case] as cause for suspending the action of the creditor, until the attachment against his debtor is determined, when it can be certainly known what the rights of the parties are," and recommending that a court facing a parallel proceeding "either suspend all proceedings until the attachment suit is determined, or render judgment with a stay of execution"). Thus, where identical cases were pending in both federal and state court, or in the courts of two different states, the defendant in the second suit was not entitled to abatement. See Penn Gen. Cas. Co. v. Pennsylvania ex rel. Schnader, 294 U.S. 189, 195 (1935) ("Where the judgment sought is strictly in personam, for the recovery of money or for an injunction compelling or restraining action by the defendant, both a state court and a federal court having concurrent jurisdiction may proceed with the litigation, at least until judgment is obtained in one court which may be set up as res adjudicata in the other.”); Kline v. Burke Constr. Co., 260 U.S. 226, 230 (1922) ("The rule, therefore, has become generally established that where the action first brought is in personam and seeks only a personal judgment, another action for the same cause in another jurisdiction is not precluded.”) (collecting cases). This requirement of concurrent jurisdiction for in personam actions developed because, under the common law, abatement would not lie if the first filed action was in a foreign court. See Vestal, supra note 170, at 528-31 (discussing historical development of rule).

By contrast, if the competing suits were in rem or quasi in rem, then regardless of jurisdictional relationship between the two courts, the second suit would be abated in favor of the first. See Penn Gen. Cas. Co., 294 U.S. at 195 ("II]f the two suits are in rem or quasi in rem, requiring that the court or its officer have possession or control of the property which is the subject of the suit in order to proceed with the cause and to grant the relief sought, the jurisdiction of one court must of necessity yield to that of the other.") (citing cases). The rationale is that "there is only one res and first court to assume jurisdiction over it withdraws it from the judicial power of the other as if it had been carried physically into a different territorial sovereignty.” 1 AM. JUR. 2D Abatement, Survival, and Revival § 18 (citing Tonnemacher v. Touche Ross \& Co., 920 P.2d 5 (Ariz. Ct. App. 1996)). The Supreme Court in Kline v. Burke Construction $\mathrm{Co}$. reasoned as follows when explaining why the separate sovereignty of the competing courts was not a relevant inquiry when the actions involved a single res:

The rank and authority of the courts are equal, but both courts cannot possess or control the same thing at the same time, and any attempt to do so would result in unseemly conflict. The rule, therefore, that the court first acquiring jurisdiction shall proceed without interference from a court of the other jurisdiction is a rule of right and of law based upon necessity, and where the necessity, actual or potential, does not exist the rule does not apply. Since that necessity does exist in actions in rem and does not exist in actions in personam, involving a question of personal liability only, the rule applies in the former but does not apply in the latter.

260 U.S. at 235.

${ }^{172}$ During the twentieth century, as judicial workloads increased, courts began to use their inherent discretionary power to stay a later filed case in favor of a prior pending action when the conditions for abatement did not exist (e.g., where there were competing in personam actions in courts of both state and federal jurisdiction). As the Seventh Circuit described, "[w]hile it seems to be well established that a federal court is not required to abate the normal in personam action on a plea of a pending action in a state court, nevertheless it is within the discretionary power of the district court to stay its proceedings pending the completion of state proceedings.” Aetna State Bank v. Altheimer, 430 F.2d 750, 756 (7th Cir. 1970), overruled by Calvert Fire Ins. Co. v. Will, 560 F.2d 792 (7th Cir. 1977), rev'd, 437 U.S. 655 (1978); see also Will, 437 U.S. at 665 ("There are sound reasons for our reiteration of the rule that a district court's decision to defer proceedings because of concurrent state litigation is generally committed to the discretion of that court. No one can seriously contend that a busy federal trial judge, confronted both with competing demands on his time for matters properly within his jurisdiction and with inevitable scheduling difficulties because of the unavailability of lawyers, parties, and witnesses, is not entrusted with a wide latitude in 
litigation grew more common during the twentieth century, the first-filed rule also became widely invoked in determining priority between representative plaintiffs. In other words, the first filed rule was not only cited to prevent a defendant from usurping a plaintiff's choice of forum by filing a subsequent action somewhere else, but also to sort out priority among plaintiffs, as when parallel class actions are filed.

Fortunately — and despite the view that the first-filed rule is and should be taken literally and applied mechanistically ${ }^{173}$ — some courts have not applied the rule in that fashion, and have from time to time acknowledged that the rule does not translate well to shareholder representative actions contemporaneously filed in multiple forums. This should not be surprising. The text of Federal Rule of Civil Procedure Rule 23, which most states have used as a model for its own class action rules, ${ }^{174}$ does not seem to work well with a mechanical first filed rule. Rather, it appears to invite judicial administration of the class action proceeding. For instance, Rule 23.1 provides that the named plaintiff must "fairly and adequately represent the interests of shareholders... who are similarly situated in enforcing the right of the corporation or association.” The requirement of fair and adequate representation may depend on the litigants' conduct, not just their speed in filing the complaint. ${ }^{175}$

setting his own calendar.”); Vestal, supra note 168, at 540 ( "[T]he courts have discretion in the manner in which they will handle the problem of judicial administration. They need not use a mechanical test such as priority of actions as used in abatement under the traditional view. There is a certain degree of discretion regarding how cases will be handled in the interest of justice.").

${ }^{173}$ See, e.g., Faith Stevelman, Regulatory Competition, Choice of Forum, and Delaware's Stake in Corporate Law, 34 DEL. J. CORP. L. 57, 110 (2009) ("[I]nflexibility or rigidity promotes the positive goals of predictability and objectivity.”).

${ }^{174}$ Stephen Burbank, The Class Action Fairness Act of 2005 in Historical Context: A Preliminary View, 156 U. PA. L. REV. 1439, 1499 (2008).

175 "A shareholder plaintiff does not sue for his direct benefit. Instead, he alleges injury to and seeks redress on behalf of the corporation. Further, the board or any shareholder with standing may represent the injured party. Thus, this Court places less emphasis on the celerity of such plaintiffs and grants less deference to the speedy plaintiff's choice of forum.” Ryan v. Gifford, 918 A.2d 341, 349 (Del. Ch. 2007); see also In re Oclaro, Inc. Derivative Litig., 2011 WL 4345099, at * 4 (N.D. Cal. Sept. 14, 2011) (considering it 
Representative shareholder suits are different from individual litigation in other ways. Unlike an individual plaintiff's case, when a different shareholder files a class or derivative action, it is not "reactive" in the usual sense. ${ }^{176}$ As far back as 1935, even before the United States Supreme Court refined the doctrine of forum non conveniens in Gilbert, the New York Supreme Court stayed a first-filed derivative suit in favor of a similar derivative suit brought two days later in Delaware. ${ }^{177}$ Additionally, shortly after the modernization of the class action in the 1966 amendments, the "the allure of state class action litigation format as an instrument of interstate forum shopping became apparent."178 Indeed, “[c]ontemporary class action practice seems to confound the basic assumption of preclusion law by preferring multiple cases to just one. This has long been true in certain substantive fields [and] overlapping class actions ha[ve] increased as the class action bar has become more entrepreneurial, more sophisticated, and more competitive.”179 As a result, plaintiffs' attorneys compete both to bring the most meritorious claims, which have the highest potential pay-out, but also to be the first to

important that the plaintiff was not only the first filed, but had actually taking the lead in consolidating parallel disputes when determining who the lead plaintiff would be in the derivative action).

${ }^{176}$ A typical reactive filing is one where the defendant races to another court house to file in the forum of its choice after the plaintiff has already filed a case. See E.I. du Pont de Nemours \& Co. v. Bayer CropScience, L.P., 2008 WL 2673376, at * 4 (Del. Ch. July 2, 2008) ("In other words, one of the underlying principles [the first filed rule] is that a plaintiff's choice of forum should be respected (assuming it is a proper forum) and a defendant should not be allowed to engage in forum shopping by subsequently filing its own complaint in another court.”).

${ }^{177}$ Levy v. Pac. E. Corp., 277 N.Y.S. 659 (Sup. Ct. 1935). The Delaware case had already been tried, and the New York court was particularly mindful under these circumstances of the potential for "unnecessary annoyance and expense to litigants in prosecuting or defending independent suits comprehending the same subject-matter." Id. With respect to priority of filing, and with laudable flexibility in applying the firstfiled "rule," the court observed that "[a]s a practical matter the pending actions may be deemed to have been simultaneously commenced and in any event priority of two days in the institution of the New York action does not necessarily control the court's discretion.” Id. What was important, then, was not priority of filing but rather the extent of effort already invested by the other court and the parties in that forum, regardless of which action was technically filed first.

${ }^{178}$ Burbank, supra note 174, at 1505.

${ }^{179}$ Id. at 1509 (citations omitted). 
settle with the defendants. ${ }^{180}$ In representative stockholder litigation, the defendants are looking to "buy" a global release from shareholder claims, no matter how weak these claims are, and will settle with the plaintiffs even when there is no additional financial benefit to the shareholders if that can ensure that a transaction they have already proposed as good for the stockholders will close in a timely manner. ${ }^{181}$ In such an environment, it is obvious why judges have been skeptical of applying a first-filed rule in shareholder representative actions, especially when there exists the potential that plaintiffs' attorneys will file cases not necessarily in the best forum for the class, but for their own pocketbooks. $^{182}$

Thus, in the context of competing shareholder representative actions, refusing to accord inflexible priority to a first-filed action solely on the basis of chronology of filing is related to an important goal of representative litigation, namely making sure that the plaintiff adequately represents the interests of the group on whose behalf the case is brought. ${ }^{183}$ Indeed, our review of the application of the first-filed rule in Delaware cases involving multi-forum shareholder representative actions - the most extensive body of such precedent-reveals that not once have the Delaware courts relied exclusively on the rule's presumption in granting a stay in favor of a representative action elsewhere that

\footnotetext{
${ }^{180}$ Griffith \& Lahav, supra note 2, at *6.

${ }^{181} \mathrm{Id}$. at $* 27-32$.

${ }^{182}$ See id. at 36-39 (discussing how judges decide, or approve awards of, attorney’s fees); infra note 184 and accompanying text.

${ }^{183}$ See also Ferguson v. Tabah, 288 F.2d 665, 672 (2d Cir. 1961) (affirming denial of stay of later-filed derivative suit despite pendency of first-filed state court derivative action, due in part to the greater breadth of claims presented, and despite describing "a judicial trend to stay subsequently initiated derivative actions to await a final decision in an earlier suit.”); Stepak v. Tracinda Corp., 1989 WL 100884 (Del. Ch. Aug. 18, 1989) (staying first-filed Delaware class action in favor of a California class action, and declining to apply the first-filed rule where service of process of the Delaware complaint did not occur until two years after filing). The availability of a summary statutory remedy has also been a persistent factor underlying decisions in Delaware not to stay corporate litigation in deference to a prior filed action elsewhere that encompassed the potential relief available under the Delaware statute. See, e.g., Coaxial Commc'ns, Inc. v. CNA Fin. Corp., 367 A.2d 994, 998 (Del. 1976) (summary statutory proceeding to compel convening of stockholder meeting); 1-5 WOLFE \& PITTENGER, supra note 42, §5.01[d].
} 
was filed earlier but reasonably contemporaneously, where the Delaware plaintiffs wished to continue the Delaware action and had not previously filed a similar representative action elsewhere. ${ }^{184}$ To the contrary, over twenty years ago, when confronted with circumstances suggesting that the first-filed rule should not be woodenly applied, Chancellor William T. Allen concluded that the rule was not “ironclad,” and should not even be applied to determine priority as between class actions that had not yet been certified as such. ${ }^{185}$ This is not to say that the courts, in Delaware and elsewhere, have not frequently given priority to a first-filed action: they have, often, but for reasons independent of mere chronological priority, and most commonly because of the advanced state of proceedings in the first-filed forum, ${ }^{186}$ or because the prior-filed suit was in

\footnotetext{
${ }^{184}$ Cf. Kaufman v. Kumar, 2007 WL 1765617 (Del. Ch. June 8, 2007) (staying derivative action in favor of suit filed over two years earlier); Teachers’ Ret. Sys. v. Scrushy, 2004 WL 423122 (Del. Ch. Mar. 2, 2004) (staying later derivative action on ground that it was filed only after the courts, lawyers, and plaintiffs involved had decided where the derivative claims would be tried); La. Emps.' Ret. Sys. v. Citrix Sys., Inc., 2001 WL 32638, at *5 (Del. Ch. Jan. 5, 2001) (partially staying action in favor of earlier filed federal class action, where the Delaware derivative claim was simply a "repackaged" version of the federal claim); Corwin v. Silverman, 1999 WL 499456 (Del. Ch. June 30, 1999) (staying derivative suit in favor of earlier filed action, where the earlier action named as defendants non-director officers who could not be parties to the Delaware action); Schnell v. Porta Sys. Corp., 1994 WL 148276 (Del. Ch. Apr. 12, 1994) (granting stay of Delaware action, filed three weeks after New York action, on forum non conveniens grounds); Lewis v. LFC Holding Corp., 1986 WL 936 (Del. Ch. Jan. 21, 1986) (staying putative class action in favor of actions that had been pending in another state for over six months); Zimmerman v. Home Shopping Network, 1989 WL 102488 (Del. Ch. Sept. 11, 1989) (staying derivative action in favor of action filed in district court over a year earlier); Hurst v. General Dynamics Corp., 583 A.2d 1334 (Del. Ch. 1990) (staying second-filed derivative action in favor of Canadian action filed over a year earlier); Schnell v. Porta Sys. Corp., 1994 WL 148276 (Del. Ch. Apr. 12, 1994) (staying second-filed derivative suit on grounds of forum non conveniens); Monheit v. O’Neil, 1980 WL 268105 (Del. Ch. Dec. 10, 1980) (staying class action brought by plaintiffs who had previously commenced similar federal litigation); H.K. Porter Co. v. Mo. Portland Cement Co., 1976 WL 2445 (Del. Ch. July 9, 1976) (staying action to determine election of directors in favor of prior and more comprehensive federal action, in which plaintiff had presented but withdrew the same claim for determination of the election).

${ }^{185}$ Jim Walter Corp. v. Allen, 1989 WL 3899 (Del. Ch. Jan. 12, 1990) (declining to stay a defendant class action despite pendency of earlier-filed Texas class action presenting overlapping issues). In Jim Walter the court supported its denial of a stay in part on the applicability of Delaware law to determine the veilpiercing issue, although the court did not regard that "as the most significant of the factors that are evaluated on a forum non conveniens motion.").

${ }^{186}$ E.g., Post v. Peters, 1989 WL 1706 (Del. Ch. Apr. 29, 1976) (staying action to enjoin stockholder meeting, brought by a plaintiff who had previously brought the same claim in California federal court, and argument had already been scheduled in that proceeding); Issen \& Settler v. GCS Enters., 1997 WL 2588 (Del. Ch. Dec. 2, 1977) (staying action challenging merger, where same plaintiffs had brought litigation in Illinois federal court three years earlier and that court had already denied a preliminary
} 
federal court and the state claims were supplemental to substantial securities law claims within the exclusive jurisdiction of the federal courts. ${ }^{187}$

Thus, the problem is one of perception: it is easy to take the doctrinal formulation of the first-filed rule too literally, and to miss the operation of the judicial discretion that is at the core of the rule. To the extent that the first-filed rule is understood as affording strongly presumptive priority to a shareholder class or derivative action filed only slightly earlier than another such action in a different forum, that understanding is unsupported by historical application of the doctrine, and is inconsistent with sound policy, as we argue below. ${ }^{188}$

\section{Diagnosing the Contemporary System's Pathologies}

Having now completed our review of the development of the doctrinal framework governing multi-forum representative litigation, we return to a topic broached earlier, ${ }^{189}$ namely the ways and extent to which that framework operates suboptimally. Our approach to this topic is more impressionistic than empirical, although we claim that it is at least informed by exposure to a steady diet of direct experience with application of the doctrinal framework. We identify two principal categories of pathologies associated with the current framework: pathologies of judicial administration, in which current doctrine leads courts and litigants into actions that unjustifiably increase the direct costs of the

injunction application); Tanzer v. Greyhound Computer Corp., 1978 WL 4953 (Del. Ch. July 26, 1978) (staying action filed by same plaintiffs as in a New York case filed 18 months earlier, where the New York court had already denied some of plaintiffs' discovery requests); DiRocco v. Roessner, 1985 WL 11567 (Del. Ch. Aug. 12, 1985) (staying class action brought only after takeover bidder's motion for preliminary injunction was denied in a prior-filed federal action).

${ }^{187}$ Corwin v. Silverman, 1999 WL 499456 (Del. Ch. June 30, 1999) (staying derivative suit in favor of prior filed federal class action that encompassed the Delaware fiduciary duty claims but also involved federal securities claims subject to exclusive federal jurisdiction); Schnell, 1994 WL 148276 (same).

${ }^{188}$ See infra Section V.A.

${ }^{189}$ See supra Part I. 
litigation system; and pathologies in which the current doctrinal framework impedes the development of bodies of precedent that promote economic efficiency.

\section{A. Pathologies of Judicial Administration}

We previously pointed out that in our current system, in which representative litigation readily extends to multiple forums, rational judges, defendants, and plaintiffs' counsel have incentives to engage in behaviors that result in deadweight costs: unnecessarily expediting litigation, accepting inadequate settlements and awarding inappropriate attorney's fees, prematurely filing derivative suits that unnecessarily engender dismissal motion practice, and inadequately supervising selection of class representatives and lead counsel. To that list, we would add one more pathology of judicial administration: namely, the concern, regularly and justifiably raised by judicial authorities, about overcrowded dockets. For example, the June 2012 report of the task force established by the Chief Judge of the State of New York to address the handling of commercial litigation in New York notes:

In New York County alone, the Justices now confront a Commercial Division docket with thousands of cases and motions—and the docket continues to grow. This burgeoning, increasingly complex workload limits the amount of time available for judges to prepare for any one case in advance of hearings, affects the atmosphere in courtrooms and delays resolution. ${ }^{190}$

Judges facing similar constraints—and complaints of that sort are legion ${ }^{191}$ — should welcome doctrinal reform that would clarify how to resolve claims of competing

\footnotetext{
190 The CHIEF Judge's TASK ForCE ON COMMERCIAL Litigation IN THE $21^{\text {ST }}$ CENTURY, REPORT AND RECOMMENDATIONS OF THE CHIEF JUdGE OF THE STATE OF NEW YORK (June 2012) at 7, available at http://www.nycourts.gov/courts/comdiv/PDFs/ChiefJudgesTaskForceOnCommercialLitigationInThe21stpd f.pdf.

${ }^{191}$ See, e.g., American Bar Association, House of Delegates Resolution 302, adopted Aug. 8-9, 2011, Report: Crisis in the Courts: Defining the Problem, at 1, 14, available at http://www.americanbar.org/groups/justice_center/task_force_on_the_preservation_of_the_justice_system.
} 
jurisdiction in representative commercial litigation. ${ }^{192}$ In the absence of any formal mechanism to prevent or minimize duplicative representative litigation, ${ }^{193}$ failure to develop and consistently apply a sensible doctrinal approach to the problem will inevitably exacerbate the burden on judicial dockets. Judicial authorities who rightfully worry about the impact of crowded dockets should no less passionately criticize a doctrinal system that does not clearly and effectively direct representative litigation involving the same transaction and the same alleged misconduct into a single forum.

html (stating "The courts of our country are in crisis," and advocating the use of specialty courts, including business courts, to promote efficiency); Chief Justice Tani G. Cantil-Sakauye, State of the Judiciary Address to a Joint Session of the California Legislature (Mar. 19, 2012), available at http://www.courts.ca.gov/17293.htm (due to court closures and layoffs necessitated by funding cuts, "[w]e are already seeing worrisome and potentially dangerous delays in the resolution of cases"); Chief Justice Barbara A. Madsen, State of the Judiciary Address (January 17, 2012), available at http://www.courts.wa.gov/newsinfo/content/stateOfJudiciary/january2012.pdf (noting that "in these tough economic times, the public's needs are at their highest levels and the courts again face a significant struggle to provide court services); Chief Justice Carol Hunstein, State of the Judiciary Address (Mar. 16, 2010), available at http://www.gasupreme.us/ press_releases/2012_soj.pdf (noting that growing caseloads and decreased funding make it "increasingly difficult [for courts] to do [their] constitutionally mandated duties”); see also Editorial, Threadbare American Justice, N.Y. TIMES, Aug. 17, 2011, http://www.nytimes.com/2011/08/18/opinion/threadbare-american-justice.html?_r=0.

${ }^{192}$ Cf. In re The Topps Co., Inc. S’holder Litig., 859 N.Y.S.2d 907, at *6 (N.Y. Sup. Ct. 2007) (emphasizing one-day filing priority and geographic contacts with New York in declining to stay a case involving directors' compliance with fiduciary duties under Delaware law, and stating "[t]here has been no showing that retention of the action would unduly burden the Commercial Division, a specialized commercial court that has been successfully handling complex commercial and corporate litigation since its inception in 1993”).

${ }^{193}$ In describing the work of the Judicial Panel on Multidistrict Litigation, Judge Heyburn points out that "The growth of multidistrict cases has created its own imperative. The Panel's work plays an increasingly important role in the distribution and reduction of the judicial workload.” Hon. John G. Heyburn II, Judicial Panel on Multidistrict Litigation: "Reflections on the Panel's Work" (Jan. 2012), at 2, available at http://www.americanbar.org/content/dam/aba/administrative/litigation/2012_jointcle_materials/ 7_2_Judicial_Panel_on_Multidistrict_Litigation_Reflections_on_the_Panels_Work.authcheckdam.pdf. He then asks, rhetorically: "Can you imagine the workload consequences to our judiciary were we unable to avail ourselves of the Section 1407 mechanism for centralization?” Id. It has been suggested, although without much hope, that a similar institution might be created to address multi-forum state litigation. Quinn, supra note 2. As Professor Quinn acknowledges, that possibility is undoubtedly unrealistic, but the suggestion does point up the importance of improving the existing framework for limiting multi-forum litigation. See also Johnson, supra note 42, at $380 \mathrm{n} .133$ (discussing the Uniform Transfer of Litigation Act $\S 201,14$ U.L.A. 677 (1991), and noting that "[p]ast efforts to institute a formal process for coordination among states have failed"). 


\section{B. Non-Authoritative Adjudication Impeding Development of Precedent}

The pathologies of judicial administration reviewed above are the most directly visible costs of the current doctrinal framework governing multi-forum representative litigation. Those costs, however, could conceivably be eliminated by any clear rule, however arbitrary, that resolved competing jurisdictional claims. A rule giving priority according to alphabetical order of plaintiffs’ names, for example, would quickly and efficiently resolve competing forum claims, and would make Angela Aalborg an extremely valuable stockholder client. Equally sensibly, one could accord priority based on which suit is filed first. ${ }^{194}$

We are interested, however, in a doctrinal approach that not only reduces the incidence and extent of competing representative litigation, but does so in ways that are less arbitrary than the current approach. Accordingly, we focus on another, less visible pathology_adjudication by forums whose decisions are neither authoritative nor the product of specialized application of governing law. As we explain below, a doctrinal framework that unduly favors such adjudication discourages societally valuable development of controlling precedent.

1. Why Concerns About Adjudicative Efficiency Apply to Corporate Law We begin that explanation by noting the importance of efficient legal enforcement mechanisms to the modern economy, and, conversely, the risk of sub-optimal adjudication of disputes. Consider, for example, the role of efficient enforcement mechanisms in the area of contract, where a widely ranging body of literature has examined how formal and informal governance mechanisms are crucial in order for

\footnotetext{
${ }^{194}$ See infra Section V.A for a critique of such a rule.
} 
parties to coordinate their future expectations. ${ }^{195}$ That ability to project exchange

through time by means of enforcing market actors' future commitments is a hallmark of modern capitalism, providing the foundation upon which impersonal, geographicallyunbounded markets are built. ${ }^{196}$

Similar to the case of contract, efficient enforcement is likewise important in the adjudication of disputes involving a corporation's internal affairs. ${ }^{197}$ Indeed, unlike European style “company laws” that often address regulatory issues, such as antitrust concerns or securities fraud, American corporate law statutes essentially operate as a specialized contract law governing the relations of the fiduciaries who manage a corporation and the corporation's stockholders. ${ }^{198}$ For example, closely held

\footnotetext{
${ }^{195}$ For useful overviews, see Michael Trebilcock \& Jing Leng, The Role of Formal Contract Law and Enforcement in Economic Development, 92 VA. L. REV. 1517 (2007), and Barak D. Richman, Firms, Courts, and Reputation Mechanisms: Towards a Positive Theory of Private Ordering, 104 Colum. L. Rev. 2328-67 (2004).

${ }^{196}$ See MORTON Horwitz, THE TRANSFORMATION OF AMERICAN LAW 1780-1860 174 (1977) (“[T]he moment at which courts focus on expectation damages rather than restitution or specific performance to give a remedy for nondelivery is ... [when] [c]ontract then becomes an instrument for protecting against changes in supply and price in a market economy.”); see also Avner Greif, Commitment, Coercion, and Markets: The Nature and Dynamics of Institutions Supporting Exchange, in HANDBOOK OF NEW InSTITUTIONAL ECONOMiCs 727, 730 (Claude Menard and Mary Shirley, eds., 2005); Michael Trebilcock \& Jing Leng, The Role of Formal Contract Law and Enforcement in Economic Development, 92 VA. L. REV. 1517, 1522-25 (2007).

${ }^{197}$ This similarity is unsurprising given the close relationship between the two bodies of law. See Mark J. Roe, Corporate Law's Limits, 31 J. LEGAL STUD. 233, 262 (2002) (“[C]orporate law . . . is in many dimensions a special form of contract law").

As defined in the Restatement (Second) of Conflict of Laws, the term "internal affairs" "concerns the relations inter se of the corporation, its shareholders, directors, officers or agents.” $\S 313$, cmt. a. We advocate a somewhat narrower definition of that term, however, that would exclude agents in general, on the theory that agency relationships with the corporation as principal are quite diverse (including ordinary employees, retained consultants, etc.) and often concentrated in a specific state, whose laws would presumably govern the agency relationship. See, e.g., RESTATEMENT (SECOND) CONFLICT OF LAWS § 291 ("The rights and duties of a principal and agent toward each other are determined by the local law of the state which, with respect to the particular issue, has the most significant relationship to the parties and the transaction under the principles stated in $\S 6$.”). The law of the state of incorporation does not ordinarily govern the relationship between the corporation and its agents, as such. See, e.g., Model Business Corporation Act subchapter E, Introductory Comment 1 ("The indemnification of employees and agents, whose duties are prescribed by sources of law other than corporation law (e.g., contract and agency law), is beyond the scope of this subchapter.").

${ }^{198}$ See Luca Enriques et al., The Basic Governance Structure: The Interests of Shareholders as a Class $\S 3.7$, in THE ANATOMY OF CORPORATE LAW (2d ed. 2009).
} 
corporations are often governed by a shareholders' agreement and a certificate of incorporation that conforms to that agreement. ${ }^{199}$ The resulting legal relationship among the participants (shareholders, directors, and officers) thus strongly resembles the relationships among the participants in what we might more readily describe as contractual entities, like limited liability companies, where the operating agreement supplements the statutory default rules in providing the framework for the relationship. Even where a corporation's shares are publicly traded and widely held, moreover, there are disputes on matters of internal corporate affairs that are also essentially contractual in nature, such as controversies over the interpretation of the dividend, voting, or other rights of preferred stock. ${ }^{200}$ In these cases, the courts have been explicit that principles applicable to contract interpretation in general are equally applicable where the interpretational issue involves a provision of the corporate charter or bylaws. ${ }^{201}$

More broadly, there is a widely held conception of the corporation as a "nexus of contracts," a term described as "shorthand for the complex arrangements of many sorts that those who associate voluntarily in the corporation will work out among themselves." ${ }^{202}$ On this view of the corporation, the same importance ascribed to consistent contract enforcement and clear judicial guidance to market actors, as discussed in the previous subsection addressing ordinary contracts, applies equally to the handling of disputes involving internal corporate affairs. It has been suggested that the "nexus of

\footnotetext{
${ }^{199}$ See, e.g., 2 MODEL Bus. CORP. ACT ANN. §7.32, at 7-272 (2011 Rev.) (“Shareholders of closely held corporations, ranging from family businesses to joint ventures owned by large public corporations, frequently enter into agreements that govern the operation of the enterprise.”).

${ }^{200}$ E.g., Alta Berkeley VI C.V. v. Omneon, Inc., 41 A.3d 381, 385 (Del. 2012); Matulich v. Aegis Communs. Essar Invs., Ltd., 942 A.2d 596 (Del. 2008); Elliott Assocs., L.P. v. Avatex Corp., 715 A.2d 843 (Del. 1998).

${ }^{201}$ E.g., Ellingwood v. Wolf's Head Oil Ref. Co., 38 A.2d 743, 747 (Del. 1944) (“In interpreting the meaning of charter provisions the same method is applied as that which is followed in interpreting written contracts generally.”).

${ }^{202}$ EASTERBROOK \& FisCHEL, supra note 4, at 12.
} 
contracts” perspective undermines the strength of the corporation's relationship with the state of incorporation, because it rejects the concept of corporations as creatures of the incorporating state, and thus denies them an "umbilical cord that would tie a dispute against a corporation to the forum of the chartering state.”203 To the contrary, we see the "nexus of contracts” perspective as strengthening that cord: the voluntary choice of law made whenever an investor joins a corporation recognizing that the law of the state of incorporation will govern its internal affairs creates a far more significant tie to the state of incorporation than this notion of the corporation as a "concession" or "creature" of the incorporating state.

\section{Forums Providing Governing Law Supply More Efficient Adjudication}

Having thus acknowledged the importance of efficient adjudication of disputes involving commercial dealings, we next submit that such efficiency is impaired by a doctrinal system that undervalues the development of controlling precedent, and the role of the courts of the forum that supplies that governing law. More specifically, in the case of the law governing voluntary private commercial relationships, it is important that courts responsible for developing that law be preferred as adjudicatory forums over courts whose application of that law is not, and will not be considered, authoritative. ${ }^{204}$

Unnecessarily deciding a case implicating a foreign jurisdiction’s commercial law robs the market of authoritative precedent, which gives important guidance in future

\footnotetext{
203 Stevelman, supra note 173 , at 77.

${ }^{204}$ We acknowledge that, in many situations where a choice of law provision has been included, the parties have also expressly chosen the forum in which disputes are to be heard. In those situations, we do not advocate disturbing the general rule that deference should be given to the parties' contractual choice of forum. See, e.g., Bremen v. Zapata Off-Shore Co., 407 U.S. 1, 9-10 (upholding deference to contractual choice of forum); Carnival Cruise Lines, Inc. v. Shute, 499 U.S. 585, 589 (1991) (accord); In re AutoNation, Inc., 228 S.W.3d 663, 668 (Tex. 2007); British W. Indies Guar. Trust Co. v. Banque Internationale A Luxembourg, 172 A.D.2d 234, 234 (N.Y. App. Div. 1991); Baker v. Impact Holding, Inc., 2010 WL 1931032, at *3 (Del. Ch. May 13, 2010) (enforcing a stockholders' agreement provision selecting a Texas forum, in a case involving the corporation's internal affairs).
} 
transactions. Parties need a single, definitive answer, not only to resolve whatever dispute they may have but also to shape future commercial dealings. The courts of the jurisdiction whose law is at stake are best positioned to provide the authoritative decision that parties and the market in general need. Denying those courts that opportunity saps a forum's law of its vitality, and in so doing undercuts the public's interest in a rich, responsive body of law that provides timely answers to ongoing issues.

Of course, judiciaries throughout the United States are staffed with competent judges capable of producing serviceable opinions applying other jurisdiction's laws. On balance, however, doctrinal complexity means that optimal applications of a jurisdiction’s law will most likely be accomplished by that jurisdiction’s courts, which are steeped in its traditions and nuances.

We say this for several reasons. First, there is a risk that a "foreign" court will misinterpret governing law, due to unfamiliarity with its nuances. Second, even a correct outcome (correct in the sense of accurately predicting how the governing law would be applied) can only be achieved with extra judicial effort, no matter how capable the judge. Learning and properly applying the law of another jurisdiction are more work for a judge than applying the law which the judge routinely encounters, and presumably the last thing judges need is extra, unnecessary work. Third, when the consistent management of cases is important to ensure that representative litigation works for its intended beneficiaries, and that excess agency costs do not compromise its integrity and effectiveness, there is an especially important interest in giving primacy to the courts of the state whose law is at stake. Finally, spreading the task of interpreting a state’s law among more judges can 
only promote greater uncertainty and less consistency in the development of the governing law. ${ }^{205}$

And in both ordinary contract law and corporate law, interstate differences in law make these two considerations non-trivial. Even in what might be thought of as "plain vanilla” contract disputes, applying another jurisdiction's contract doctrines poses a number of challenges. Subtle yet important substantive differences exist between jurisdictions' canons of contract law. ${ }^{206}$ In other words, jurisdictions have differing articulations of the same rules. Second, certain jurisdictions specialize in the interpretation and enforcement of particular types of agreements, meaning that some judiciaries will have precedent and experience that is absent in other states. ${ }^{207}$ These two factors belie the view that a different state's contract doctrines are susceptible to easy application by a court unfamiliar with them.

Likewise, states vary in their treatment of issues of corporate law, even where those issues appear formally identical and do not involve divergent statutory formulations.

\footnotetext{
205 J. Clark Kelso, A Report on the California Appellate System, 45 HASTINGS L.J. 433, 448 (1994) ("The more judges there are deciding the cases, the more likely there will be conflicts in the law stemming from inconsistent interpretations of the law and case precedents.").

${ }^{206}$ See Geoffrey P. Miller, Bargains Bicoastal: New Light on Contract Theory, 31 CARDOZO L. REV. 1475 (2010) (identifying differences between California and New York contract law in over a dozen doctrines, including: the obligation to negotiate in good faith; the use of promissory estoppel to impose liability for preliminary negotiations; the role and nature of consideration; when duress, unconscionability, or public policy considerations render a contract unenforceable; the scope of the statute of frauds; when mistake excuses performance; the use of parol evidence; the enforceability of choice of law and forum selection provisions; the enforceability of agreements to shape the adjudicatory process (e.g., arbitration provisions, jury trial waivers, class action waivers, etc.); and the scope of extra-contractual liability (e.g. unjust enrichment and quantum meruit).

${ }^{207}$ For example, of the samples of agreements examined in two of Eisenberg and Miller's studies, nearly every credit commitment agreement, underwriting agreement, pooling \& servicing agreement, and security agreement chose New York law to govern, while nearly every trust agreement chose Delaware law. See Theodore Eisenberg \& Geoffrey Miller, The Flight to New York: An Empirical Study of Choice of Law and Choice of Forum Clauses in Publicly-Held Companies' Contracts 27-28 (New York University Law and Economics Working Paper No. 124 2008) (working paper version). Similarly, Delaware law is chosen most often to govern merger agreements. Theodore Eisenberg \& Geoffrey Miller, Ex Ante Choices of Law and Forum: An Empirical Analysis of Corporate Merger Agreements, 59 VAND. L. REV. 1975 (2006); Matthew Cain \& Steven M. Davidoff, Delaware's Competitive Reach (University of Connecticut School of Law Working Paper 2010).
} 
Thus, for example, state courts have varied in their treatment of the question of whether a sale of the corporation's assets should be regarded as a "de facto merger:" some courts have viewed the asset sale as an evasion of statutory appraisal rights applicable to mergers because it achieves the same basic economic result as a merger; ${ }^{208}$ other courts, however, including Delaware's, have been guided by the "independent legal significance” or "equal dignity" doctrine, under which a transaction structured as a sale of assets and governed by a statute not providing for appraisal rights cannot be tested by and subject to requirements imposed under a different statute (the merger statute). ${ }^{209}$

For another example, consider the treatment of fiduciary duties of directors to creditors, and the rise and (perhaps) fall of the so-called "deepening insolvency" doctrine: before the Delaware courts had an opportunity to squarely consider the viability of that doctrine, other courts had construed applicable Delaware law to establish a cause of action against corporate directors for fraudulently continuing the corporation’s existence and exacerbating (“deepening”) its insolvency. ${ }^{210}$ When the matter came before the Delaware courts, however, the “deepening insolvency” doctrine failed to pass muster as a matter of Delaware law ${ }^{211}$ — thereby illustrating the concern that courts unfamiliar with the deep structure of a body of law run a high risk of getting that law wrong, or at least

\footnotetext{
${ }^{208}$ Farris v. Glen Alden Corp., 143 A.2d 25 (Pa. 1958); Applestein v. United Board \& Carton Corp., 159 A.2d 146, 152-153 (N.J. Super.), aff'd, 161 A.2d 474 (N.J. 1960); see also Kan. City Power \& Light Co. v. W. Res., Inc., 939 F. Supp. 688 (W.D. Mo. 1996) (treating a two-step transaction as a long-form merger subject to the statutory two-third shareholder vote requirements because the result of the transaction was the same as a long-form merger, and rejecting application of the doctrine of independent legal significance). ${ }^{209}$ E.g., Hariton v. Arco Electronics, Inc., 188 A.2d 123 (Del. 1963).

${ }^{210}$ OHC Liquidation Trust v. Credit Suisse First Boston (In re Oakwood Homes Corp.), 340 B.R. 510, 2006 WL 864843, at * 16-17 (Bankr. D. Del. Mar. 31, 2006) (holding that Delaware, New York, and North Carolina would recognize a cause of action for deepening insolvency); In re Exide Techs., Inc., 299 B.R. 732 (Bankr. D. Del. 2003) (following Official Comm. of Unsec. Creditors v. R.F. Lafferty, 267 F.3d 340 (3d Cir. 2001) (recognizing deepening insolvency as a cause of action under Pennsylvania law)).

${ }^{211}$ Trenwick Am. Litig. Trust v. Ernst \& Young, L.L.P., 906 A.2d 168, 174, 204-207 (Del. Ch. 2006).
} 
wrong in the sense of incorrectly predicting how the courts of the state supplying the governing law would apply the law.

Our arguments in this section can be summarized by reference to the literature, rooted in economics but cross-disciplinary in nature, that has developed over the years to examine the relationship between legal institutions and markets. ${ }^{212}$ That scholarship understands legal institutions as a necessary condition to the impersonal markets that characterize modern capitalism. ${ }^{213}$ In short, legal institutions facilitate exchange and investment by: (1) protecting property rights; (2) vindicating contractual expectations; and (3) providing a menu of entities by which joint investment can be organized and financed. ${ }^{214}$ The law is an infrastructure upon which markets rely. Put in those conceptual terms, the problems discussed in this section can be summarized as follows: there is a growing mismatch between the privately-ordered arrangements parties use to organize and finance economic activity and the legal infrastructure designed to support them. As markets have evolved and economic

\footnotetext{
${ }^{212}$ This literature has roots in the work of Weber and other early institutionalists, received firmer conceptual foundations through Coase's work, see Ronald Coase, The Nature of the Firm, 4 EconomiCA 386 (1937) and Ronald Coase, The Problem of Social Cost, 3 J.L. \& Econ. 1 (1960), and has matured into a multidisciplinary effort spanning economics, political economy, economic sociology, law, business history, etc. See, e.g., AlfRed CHANDlER, The VisiBle HAND (1974); Douglass NORTH, INSTITUTIONS, INSTITUTIONAL CHANGE AND ECONOMIC PERFORMANCE (1990); ELINOR OSTROM, GOVERNING THE COMmons: THE Evolution of Institutions For ColleCtive ACTION (1990); Michael Piore \& CHARLES SABLE, THE SECOND INDUSTRIAL Divide (1984); Oliver E. Williamson, THE ECONOMIC InSTITUTIONS OF CAPITALISM (1985); Mark Granovetter, Economic Action and Social Structures: The Problem of Embeddedness, 91 AM. J. SociolOGY 481 (1985).

${ }^{213}$ See HORWITZ, supra note 196, at 174.

${ }^{214}$ ThrÁINN EGGERTSSON, ECONOMIC BEHAVIOR AND INSTITUTIONS 48 (1990) (“The state, by using its police power and the courts, assists private individuals in enforcing legitimate contracts and thus lowers the costs of exchange, particularly when the state uses its power to enforce contracts in a systematic and predictable manner."). In the 1980s and 1990s, this view of law's relationship to economic development was implemented into public policy as the so-called "Washington Consensus," which emphasized the liberalization of markets and the privatization of industry. See WORLD BANK, WORLD DEVELOPMENT REPORT 1997, at 41 (1997).
} 
organization has become global in scope, the corresponding legal institutions have lagged in their response. The task at hand, then, is to recalibrate the law so that it once again is responsive to the needs of the ever-evolving modern economy. Given the broad understanding of that evolution, it has become increasingly important as a matter of public interest to tailor legal doctrine to give more appropriate and significant effect to contract expectations in litigation over essentially contractual relationships.

\section{Rationalizing Parallel Litigation in Corporate Disputes}

In this section, we set forth our recommendations for correcting the current system's dysfunction. We make three basic recommendations to address the principles of laws that judges must apply when resolving which forum should be given primacy when identical or overlapping cases are filed in multiple jurisdictions. We thus focus closely on the Restatement provisions that bear most directly on this subject from the Restatement Second of Conflict of Laws as well as the general common law principles. First, we propose that the so-called common law first-filed rule be jettisoned in its current form, at least in the case of representative corporate litigation, and be replaced by more concrete considerations of efficiency. Second, we recommend re-calibrating the factors in forum non conveniens analysis. Although a state's interest in interpreting its own laws is a commonly enumerated factor in forum non conveniens analysis, it is only one consideration among several equally-weighted concerns in most states and the Restatement.

We propose changing that relationship. Rather than treating the litigants' choice

of law as just one factor among many, we recommend giving presumptive weight to that choice of law when determining whether a given forum is appropriate in a parallel 
litigation situation, and lesser weight to geographic considerations that have become much less compelling with the advent of advanced communications technologies. Our third recommendation, which applies specifically to corporate law disputes, is to amend the Restatement's articulation of the internal affairs doctrine in similar fashion. Currently, the internal affairs doctrine is typically formulated as follows: "A court will exercise jurisdiction over an action involving the internal affairs of a foreign corporation unless it is an inappropriate or an inconvenient forum for the trial of the action." ${ }^{\text {,15 }}$ We propose changing that formulation to: "A court will not exercise jurisdiction over an action involving the internal affairs of a foreign corporation where there is a contemporaneously filed parallel action in the forum of incorporation.”

Our recommendations are unique in at least this respect: unlike scholarly responses to the parallel litigation problem that suggest procedural solutions focused upon case management, ${ }^{216}$ our prescriptions are tailored to foster the continued, consistent development of substantive doctrines. Our different approach arises from our understanding of courts’ role in underpinning market exchange, and not only from a concern about overcrowded dockets (though that also motivates our prescriptions). In our view, suggestions that only recommend expanding courts' discretion to stay or

\footnotetext{
${ }^{215}$ RESTATEMENT (SECOND) CONFLICT OF LAWS § 313 (1971).

${ }^{216}$ For example, Rhonda Wasserman has proposed a range of solutions, from creating a registry that would give courts better notice of overlapping class actions and amending Rule 23 to make certification of a second class action more difficult, to enacting legislation at state and federal level to enable the consolidation of competing class actions. Rhonda Wasserman, Dueling Class Actions, 80 B.U. L. REV. 461, 528-41 (2000). Alan Morrison has suggested a variant on the Class Action Fairness Act of 2005 that would give defendants the power to remove and consolidate derivative suits into federal court; unlike the actual Class Action Fairness Act, this statute would not exclude actions that "relate[] to the internal affairs or governance of a corporation," and removal would be discretionary and not automatic. 28 U.S.C. § 1453(d) (2006); Alan B. Morrison, Removing Class Actions to Federal Court: A Better Way to Handle the Problem of Overlapping Class Actions, 57 STAN. L. REV. 1521 (2005) (critiquing the Class Action Fairness Act of 2005). Sean Griffith and Alexandra Lahav have criticized proposals that would "force federalization" of class actions, and instead have urged courts facing competing class actions to confer among themselves and to decide which jurisdiction should hear the case. Griffith \& Lahav, supra note 2, at *53, *59-77.
} 
dismiss parallel cases without expressly taking choice of law considerations into account are bound to perpetuate the current problem. ${ }^{217}$

\section{A. What Interests Merit Consideration in Resolving Competing Representative Corporate Litigation?}

Before presenting such a solution, however, we turn first to a foundational

question: in evaluating competing jurisdictional claims in representative corporate

litigation, whose interests should be considered?

The concern articulated in the previous Section was that it is relatively inefficient and costly for courts in states that do not supply the law chosen to govern commercial dealings to adjudicate disputes involving application of that law. At least as to litigation involving internal corporate affairs, expression of this concern is nothing new. The Restatement asserts that "uniformity of result, as well as the giving of proper attention to local custom that is not reflected in law books, can best be assured by having the action

\footnotetext{
${ }^{217}$ One-forum motions, which are filed in parallel jurisdictions simultaneously and ask the courts to confer with one another in order to decide which action should proceed, are also of little utility: they are unnecessary where a foreign court is predisposed to defer to the forum whose law is at stake and useless where a judge is determined to keep the case. Furthermore, one-forum motions can provide a pretext for courts who want to cling to cases for the wrong reasons, further calling for a more effective and influential doctrinal solution that judges would more likely respect.

Exclusive choice of forum provisions in corporate bylaws and charters dispense at least nominally with room for such judicial discretion. See Quinn, supra note 2, at 141-42, 144 n.22. The efficacy of such provisions, however, depends upon their enforceability throughout the nation, and not all courts enforce forum choices even in bilateral contracts. See Idacorp, Inc. v. Am. Fiber Sys., 2012 U.S. Dist. LEXIS 135049 (D. Idaho Sep. 19, 2012) (invoking Idaho Code § 29-110, providing that "every stipulation or condition in a contract, by which any party is restricted from enforcing his rights under the contract by the usual proceedings in the ordinary tribunals ... is void," to refuse to enforce a choice of forum in a bilateral asset acquisition agreement). Even in jurisdictions (most of them, we acknowledge) that give effect to forum choice provisions in bilateral contracts, precedent governing forum choice provisions in charters and bylaws is sparse, and not all courts have enforced such provisions. Galaviz v. Berg, 763 F. Supp. 2d 1170 (N.D. Cal. 2011) (declining to apply forum choice bylaw adopted by directors after the conduct giving rise to the derivative claims asserted). Moreover, even if exclusive forum provisions are enforceable and are drafted to afford the defendant corporation the flexibility to waive the provision and permit litigation to go forward in a different forum, they still do not permit courts to bring considerations of public interest to bear in determining where litigation ought to proceed.
} 
tried in the state of incorporation.”218 Indeed, the Restatement notes that this consideration counsels in favor of dismissing a suit based upon the law of the state of incorporation, "even in a situation where the court, if it were to hear the case, would apply the local law of the state of incorporation in reaching its decision.”219

Shortly after making these compelling points, however, the Restatement commentary undermines their force by retreating back to and, in our view, unduly emphasizing geographic considerations: it urges that the forum state exercise jurisdiction where the corporation is “only technically a foreign corporation" because its business "is carried on entirely or principally in the state of the forum and when the directors of the corporation or a majority of them reside in the state and are accustomed to hold meetings in the state ....”220 This reference back to geographic considerations is, we submit, misguided. In corporate class or derivative actions, the issues presented-usually whether directors or officers have comported themselves in accordance with their fiduciary duties, or how the rights of stock or stockholders under the corporation's charter or bylaws are to be interpreted—are matters that most directly and meaningfully affect the interests of shareholders, and not those of corporate customers or suppliers or employees. In most cases of corporate representative litigation, the meaningful interests at stake do not arise from the physical location of the corporation's business activities, or where its directors happen to meet; ${ }^{221}$ to the contrary, it is the impact (direct or indirect)

\footnotetext{
${ }^{218}$ RESTATEMENT (SECOND) OF CONFLICT OF LAWS $§ 313$ cmt. c (1971).

${ }^{219} \mathrm{Id}$.

${ }^{220} \mathrm{Id}$.

${ }^{221}$ See ABRY Partners V, L.P. v. F\&W Acquisition LLC, 891 A.2d 1032, 1049 (Del. Ch. 2006) (in determining choice of law in a commercial dispute, discounting significance of buyer's physical location, and noting that "the place of injury is less significant in the case of fraudulent misrepresentations") (quoting RESTATEMENT (SECOND) CONFLICT OF LAWS § 145 cmt. f (1971)).
} 
of the directors' and officers' conduct upon investors that represents the most significant concern.

We acknowledge that the primacy of shareholder interests in the corporation has long been a matter of debate, and that many states have adopted so-called "constituency statutes” that arguably dilute that generally accepted primacy to some uncertain extent. ${ }^{222}$ This interesting debate, however, should not obscure that fact that it is shareholders who bring shareholder derivative suits, and shareholders who bring shareholder class actions, on behalf of the corporation or other shareholders as class members. Almost universally, moreover, it is only shareholders, and not employees or any other constituency, which have the power to elect the corporation's directors. ${ }^{223}$ In any event, the existence of a “constituency statute” in a forum state other than the state of incorporation should do nothing to favor the forum state as the situs of representative shareholder litigation. The decision as to whether and to what extent corporate statutory law should protect other constituencies is a matter for the state of incorporation to decide. Even if a particular constituency enjoys fiduciary attention by virtue of a constituency statute, that statutory choice carries no weight, under well-settled principles of choice of law, ${ }^{224}$ unless that statute is adopted by the state of incorporation. There is no basis on which to require regard for that constituency under the corporate laws of a state other than the state of

\footnotetext{
${ }^{222}$ For some of the leading expressions on this subject, see, e.g., Stephen M. Bainbridge, Interpreting Nonshareholder Constituency Statutes, 19 PePPERDINE L. REV. 971, 992-93 (1992); Committee on Corporate Laws, Other Constituencies Statutes: Potential for Confusion, 45 Bus. LAW. 2253 (1990); William W. Bratton \& Michael L. Wachter, Shareholder Primacy's Corporatist Origins: Adolf Berle and “The Modern Corporation," 34 J. CORP. L. 99 (2008); Lynn Stout, Bad and Not-So-Bad Arguments for Shareholder Primacy, 75 S. CAL. L. Rev. 1189 (2002); Leo E. Strine, Jr., The Social Responsibility of Boards of Directors and Stockholders in Change of Control Transactions: Is There Any "There" There?, 75 S. CAL. L. REV. 1169, 1170-73 (2002).

${ }^{223}$ E.g., MODEL Business CORPORATION ACT §8.03(c) (directors elected at annual shareholders' meeting); DEL. CoDE ANN. tit. 8, §§211(c), 221 (directors elected at annual stockholder meeting, unless certificate of incorporation confers voting rights on holders of bonds, debentures or other obligations of the corporation). ${ }^{224}$ See supra note 121.
} 
incorporation. Thus, judges in states with constituency statutes must apply those statutes only to their own domestic corporations, and respect the choice of other corporations to incorporate in non-constituency states. If a corporation of a state without a constituency statute is involved in corporate law litigation in a state with a constituency statute, on what basis can the presence of constituencies in that state not protected by the applicable law of the state of incorporation be a justification for the courts of the state with a constituency statute to exercise jurisdiction over the corporate law dispute? In that circumstance, those constituencies have no case-specific interest in the matter and are irrelevant to any rational resolution of a forum conflict. Rather, the limited reach of constituency statutes highlights that in a forum conflict, the tribunal whose substantive corporate law must govern has the highest policy interest and should decide the dispute.

Indeed, the Restatement does not seem to apply, on its own terms, to public companies, because it is unlikely that a public corporation’s business would be “carried on entirely or principally in the state of the forum.” But, even when this is the case, and the corporation's directors reside in and hold their meetings entirely in the forum state, the interests of that state are secondary at best because those with the greatest interest in the litigation—-the public shareholders—are scattered widely among the states. Thus, in a publicly held corporation with widely traded shares, it is most likely that no single state could claim to have an interest in a representative corporate lawsuit superior to that of the state supplying the governing law (the state of incorporation). ${ }^{225}$ In an era of increasing

\footnotetext{
${ }^{225}$ Under our analysis, the state where certain stakeholder groups are concentrated—such as employees—is not relevant, because corporate representative litigation does not seek to redress harm to these groups, except insofar as the members of these groups are also investors. Furthermore, looking to which state has the dominant interest based on the location of the investors in the corporation would create its own problems. Such a claim of dominant interest could not rest upon a mere head count of resident shareholders: any geographic assessment of impact on shareholders would also have to take into account the shareholders' level of investment. Thus, for example, simply having more shareholders resident in
} 
institutional investor ownership, ${ }^{226}$ moreover, even the "residence” of shareholders

becomes an abstract and obscure proposition, where equity securities are held by

intermediary institutional investors for the ultimate benefit of yet another geographically dispersed set of beneficiaries. $^{227}$

As important, a represented member of a stockholder class cares little about having her state of residency's courts address a case. What she wants is her reasonable expectations as an investor vindicated - expectations based on the law of the state of incorporation. The reality, moreover, is that the plaintiffs in stockholder representative actions do not sue for the most part in their own domiciles anyway. ${ }^{228}$ When a plaintiff sues on behalf of a class, that plaintiff's at most minimal interest in geographic convenience must as a matter of principle be subordinated to the class's interests in

California would not militate in favor of keeping a proceeding in the courts of that state if a far smaller number of New York-based shareholders nevertheless had a far larger investment in the company, and therefore had a considerably more significant interest in the outcome of representative litigation involving the company.

${ }^{226}$ See, e.g., Donald C. Langevoort, The SEC, Retail Investors, and the Institutionalization of the Securities Markets, 95 VA. L. REV. 1025, 1026 n.4 (2009) (noting that "institutions owned 73.4\% of the market value of outstanding equity securities in 2006”) (citing SEC. InDUS. \& FIN. MKTS. Ass’N, 2007 FACT BOOK 65 (Charles M. Bartlett, Jr. ed., 2007)).

${ }^{227}$ For example, a mutual fund may have its principal offices in, say, Boston, but the fund's shareholderswhose economic interests in the fund's portfolio shares are ultimately the interests most importantly, albeit indirectly, affected by the outcome of corporate class and derivative litigation—may and likely do reside in many states in addition to Massachusetts. Thus, it seems unproductive to determine an appropriate forum even by reference to which state has the highest concentration of equity investment in the firm, as determined by the nominal address of the shareholder. Cf. In re The Topps Co., Inc. S'holder Litig., 859 N.Y.S.2d 907, at *19 (Sup. Ct. 2007) (attaching significance to the fact that "four of the company's six largest shareholders are located in New York").

${ }^{228}$ Examples of forum choices of several regular institutional shareholder plaintiffs illustrate this geographic indifference to the forum in which they are headquartered. E.g., Frederick v. Mechel OAO, 475 Fed. App’x 353 (2d Cir. 2012) (City of Westland, Michigan, Police and Fire Retirement System acting as co-plaintiff in securities class action filed in New York); In re Cendant Corp. Litig., 264 F.3d 201 (3d Cir. 2001) (California Public Employees' Retirement System acting as co-plaintiff in securities class action filed in New Jersey); City of Pompano Beach Gen. Emps.' Ret. Sys. v. Synovus Financial Corp., 2009 WL 4641804 (N.D. Ga. Dec. 1, 2009); (Florida pension fund suing in securities action in Georgia); In re Royal Ahold N.V. Secs. \& Erisa Litig., 351 F. Supp. 2d 334 (D. Md. 2004) (Public Employees Retirement Association of Colorado acting as lead plaintiff in securities action heard in Maryland); La. Mun. Emps.' Ret. Sys. v. Cablevision Sys. Corp., 904 N.Y.S.2d 492 (2010) (Louisiana pension fund suing in fiduciary duty action in New York); State of Wisc. Inv. Bd. v. Bartlett, 2000 WL 238026 (Del. Ch. Feb. 24, 2000); (Wisconsin pension fund suing as class plaintiff in fiduciary duty class action in Delaware). These are illustrative examples; and we expect that readers could identify many more. 
getting the most authoritative ruling they can under the law they chose to govern the investment. But even if somehow the convenience of the representative plaintiffs to some extent must be balanced against the fair expectations of the represented, that reasoning has no relevance when a plaintiff files outside its own state, as is typically the case. $^{229}$

This reality also illustrates another reason why the Restatement's approach is outdated. In a typical corporate case, the defendants produce almost all of the discovery and face all of the real burden. Modern litigation alleviates this by allowing the discovery to occur where the evidence is: it has long been traditional in corporate cases in Delaware and securities cases in the federal district courts for discovery to occur where the evidence is located, thus limiting any inconvenience to those producing the discovery materials. $^{230}$ The named plaintiffs in stockholder litigation bear almost no burden. Their lawyers will travel wherever the case is litigated. In most situations, the defendants will find it as convenient to have the case tried in the state of incorporation or in the headquarters state, because the location of discovery will not change, many directors are dispersed anyway, and thus the only incremental cost to getting an authoritative ruling from the courts whose law is at stake is the modest one of traveling for actual in-court hearings. This modest incremental cost is usually in fact non-existent to the plaintiffs' lawyers, who must travel anyway and whose clients are rarely witnesses.

\footnotetext{
${ }^{229} \mathrm{Id}$.

${ }^{230}$ See WOLFE \& PiTTENGER, supra note 45, § 6.05[a] (“the deposition of an individual defendant typically is taken at his or her residence or place of employment, and the deposition of an organization, through one of its directors or agents, generally is taken at the principal place of business of the organization.”); 7-34 MOORE’s FEDERAL PRACTICE - CIVIL $\S 34.14$ ("When the documents are needed by a party for use in the transaction of its business, the inspection should generally take place at the party's place of business.”).
} 
In sum, the one and only interest most consistently and directly affected by class and derivative litigation relating to the corporation's internal affairs is the interest of the corporation's equity investors. And the geographic focus of the class as investors is singular, unified, and focused on the state of incorporation whose law they have chosen to govern their investment. Accordingly, and as we argue above, the most compelling interest at stake is the investors' interest in promoting the orderly, consistent, and full development of the law governing the corporation's internal affairs. That is, the physical residence of particular stockholders bears no relation to where they want corporate cases decided. In a class action, giving weight to the geographic preference of a named plaintiff is not only irrational in the sense of having no logical relation to any legitimate interest of the class, it is unworkable as a tie-breaking rule. If a Texas-resident plaintiff favors litigation in Texas and a New York-based plaintiff prefers litigation in New York, whose interest prevails in deciding where a class of diversely resident stockholders get their rights decided? Or to use a more common scenario, when a Texas-resident plaintiff wants a class action decided in Iowa, and a New York-based plaintiff wants a class action decided in California, who prevails? The answer, if it is to be based on the best interests of the class, has to give no weight to the physical residence of the filing plaintiffs.

If one is inclined to treat investors as adults, as we are, we find it far more likely that the investor's choice to invest in particular corporation reflects in part the investor's view that the governing corporate law is one that is acceptable and perhaps even beneficial. ${ }^{231}$ And that interest therefore ordinarily suggests that disputes over the corporation's internal affairs, at least for publicly held corporations, should presumptively go forward in the courts of the state of incorporation.

${ }^{231}$ See Roberta Romano, The Genius of American Corporate LaW 57 (1993). 
Our suggestion does not accommodate one-way application: courts (notably the Delaware courts) accustomed to resolving questions of internal corporate affairs should be receptive to dismissing or staying litigation presenting claims arising primarily under the laws of another state or jurisdiction. In this regard, we commend the Texas federal district court's dismissal of shareholder derivative litigation involving the BP/Deepwater Horizon oil well explosion of 2010, in favor of litigation in the United Kingdom, where the controversy, involving claims of breach of fiduciary by the directors of a U.K. corporation, was controlled by a newly enacted British corporate statute. ${ }^{232}$ We expect, as well, that Delaware courts would be equally receptive to dismissing or staying cases based on the business entity or other private commercial laws of other jurisdictions, and overall we find that they are. ${ }^{233}$

\footnotetext{
${ }^{232}$ In re BP S’holder Derivative Litig., 2011 WL 4345209, at *12 (S.D. Tex. Sept. 15, 2011) (“At base, this case seeks to resolve questions surrounding the appropriate internal governance of an English company. In such situations, courts have found that the country of incorporation has the greatest interest. ... [T]his lawsuit is not intended to redress the devastating impact of the Deepwater Horizon disaster in the United States. Instead, the lawsuit is intended to compensate BP for the financial and reputational harm the company suffered as a result of its high level management's alleged disregard for the safety of its operations. The English courts have a greater interest in resolving a dispute related to the internal governance of an English company, especially one about whether the company's directors violated their fiduciary duties.”). Cf. Bushansky v. Armacost, 2012 WL 3276937, at *4 (N.D. Cal. Aug. 9, 2012) (staying derivative action in favor of state court class action presenting the same issues, and noting that "judges in Delaware are more familiar with Delaware state law than judges in California. Given the high likelihood that this entire case is governed by Delaware law, there is wisdom in letting Delaware judges decide these issues.").

${ }^{233}$ See, e.g., TA Instruments-Waters, LLC v. Univ. of Conn., 31 A.3d 1204 (Del. Ch. 2011) (declining to expedite litigation challenging compliance with Connecticut law on public bidding on a contract with the University of Connecticut); Trans. of Oral Arg., Walton v. Apollo Global Mgmt. LLC, C.A. No. 5216-VCS, at *25-28 (Del. Ch. Jan. 29, 2010) (staying action claiming breach of fiduciary duty by general partner of a Delaware limited partnership, where the limited partnership agreement defined the corporate general partner's fiduciary duties to the limited partners by reference to the law establishing the duties of directors of the corporate general partner, an Ohio corporation); Third Ave. Trust v. MBIA Ins. Corp., 2009 WL 3465985 (Del. Ch. Oct. 28, 2009) ("[T] he notes [at the heart of the dispute] were issued in accordance with the New York Insurance Law, the [contract governing noteholders' rights] is governed by New York contract law, and [the plaintiff's] claims are based entirely upon New York, not Delaware, statutes and common law. Because of the importance of this question to New York public policy, and the absence of any legitimate interest Delaware has in the question, I believe that an appropriate regard for comity requires this court to abstain and allow the courts of New York to speak on the collateral effect to be given to the determinations of the Superintendent of the New York Insurance Department.”); Diedenhofen-Lennartz v. Diedenhofen, 931 A.2d 439, 442, 451 (Del. Ch. 2007) ("Of all the states of the union, Delaware should be
} 


\section{B. Proposed Doctrinal Improvements}

\section{Eliminate Mere Priority of Filing as a Relevant Consideration}

As explained earlier, courts in Delaware and elsewhere have traditionally

accorded great deference to a plaintiff's choice of forum, holding that a "plaintiff ... is

afforded the presumption that its choice of forum is proper and a defendant who attempts

to obtain dismissal based on grounds of forum non conveniens bears a heavy burden.,234

Especially in the context of representative corporate litigation, however, the

problem of multi-forum litigation calls into question the rationality of this doctrinal

deference. Where a plaintiff is seeking to vindicate solely her own interests, deference to

the plaintiff's autonomy in selecting a forum may give effect to a meaningful social value.

In the corporate context, however, the value of that selection is decidedly less meaningful.

If nothing else, the representative derivative plaintiff does not seek relief for himself; he

most sensitive to the need to afford comity to the courts of the jurisdiction that charters an entity. . . . The Delaware courts have long asserted that this state has a compelling interest in the efficient and consistent application of its laws governing business entities. . . . Delaware has a related and equally important interest in affording comity to the courts of other jurisdictions when a dispute arises under foreign business law.”); IM2 Merchandising \& Mfg., Inc. v. Tirex Corp., 2000 WL 1664168, at*10 (Del. Ch. Nov. 2, 2000) (dismissing on forum non conveniens ground a case based primarily on the contract law of Quebec, and recognizing that " $[\mathrm{t}]$ he great weight given to a plaintiffs interest in having novel Delaware law questions, decided in our own courts . . . suggests that a defendant's interest in having the courts of the jurisdiction of the governing law decide important legal issues ought also be given some weight. This is especially so when the plaintiffs themselves chose the laws of that jurisdiction to govern their relations with the defendants”); Colonial Secs. Corp. v. LTV Corp., 1979 WL 4626, at *4 (Del. Ch. July 18, 1979) (staying Delaware class action on behalf of debenture holders alleging fraud in connection with redemption of convertible debentures, and finding that Delaware incorporation of both plaintiff and defendant is “irrelevant” in this context); see also McDermott, Inc. v. Lewis, 531 A.2d 206 (Del. 1987) (reversing a judgment regarding voting rights of shares of a Panamanian corporation due to lower court's application of Delaware and Louisiana law). But cf. Berger v. Intelident Solutions, Inc., 906 A.2d 134, 135 (Del. 2006) (reversing dismissal on forum non conveniens grounds of an action based on Florida corporation law, finding no “overwhelming hardship” justifying dismissal); Taylor v. LSI Logic Corp., 689 A.2d 1196, 1197, 1199-1201 (Del. 1997) (reversing dismissal on forum non conveniens grounds of an action involving Canadian corporate law, reasoning that overwhelming hardship and inconvenience justifying dismissal was not established).

${ }^{234}$ Mar-Land Indus. Contractors, Inc. v. Caribbean Petroleum Ref., L.P., 777 A.2d 774, 777-78 (Del. 2001); Durkin v. Intevac, Inc., 782 A.2d 103, 111 (Ct. 2001); Ex parte Preston Hood Chevrolet, Inc., 638 So.2d 842, 845 (Ala. 1994); Torres v. Walsh, 456 N.E.2d 601, 607 (Ill. 1983). 
seeks a recovery for the corporation. ${ }^{235}$ As the United States Supreme Court explained in Koster in 1947, “where there are hundreds of potential plaintiffs, all equally entitled voluntarily to invest themselves with the corporation's cause of action and all of whom could with equal show of right go into their many home courts, the claim of any one plaintiff that a forum is appropriate merely because it is his home forum is considerably weakened.”236 The distinction between derivative and class action litigation is irrelevant for the application of this common sense and, to us, irrefutable logic. The intellectual and policy claim of a representative plaintiff's choice of forum is at best weak, in class as well as in derivative actions, when compared to the represented's interest in having the matter decided by the judiciary whose law the represented rely upon to govern their investment. $^{237}$

Discounting the significance of a representative plaintiff's choice of forum is appropriate, in our view, regardless of one's opinion about the professionalism or integrity of plaintiff's counsel; ${ }^{238}$ one could assume purely altruistic motives on the part

\footnotetext{
${ }^{235}$ See, e.g., Ryan v. Gifford, 918 A.2d 341, 349 (Del. Ch. 2007); Biondi v. Scrushy, 820 A.2d 1148, 1159 (Del. Ch. 2003).

236330 U.S. at 524.

${ }^{237}$ Delaware law provides precedent in this regard, holding that, in the representative context, a court is to "give[] less weight to the first-filed status of a lawsuit, and instead will examine more closely the relevant factors bearing on where the case should best proceed using something akin to . . . a forum non conveniens analysis.” In re Citigroup Inc. S’holder Derivative Litig., 964 A.2d 106, 117 (Del. Ch. 2009); see also Ryan v. Gifford, 918 A.2d 341, 349 (Del. Ch. 2007) ("A shareholder plaintiff does not sue for his direct benefit. Instead, he alleges injury to and seeks redress on behalf of the corporation. Further, the board or any shareholder with standing may represent the injured party. Thus, this Court places less emphasis on the celerity of such plaintiffs and grants less deference to the speedy plaintiff's choice of forum.”); WOLFE \& PITTENGER, supra note 42, § 5.01[c], at 5-20 ("While the principles of [the first-filed rule] are not entirely disregarded in the context of competing stockholder representative suits, it is now clear that the first-filed complaint will be given decidedly less deference in that context."); note 150, supra (citing La. Mun. Police Emps.' Ret. Sys. v. Medco Health Solutions, Inc., 46 A.3d 313, 337 (Del. Ch. 2012) and Biondi v. Scrushy, 820 A.2d 1148, 1158-59 (Del. Ch. 2003)).

${ }^{238}$ Cf. Stevelman, supra note 173, at 113 (stating that discounting the derivative plaintiff's choice of forum "reflects the Court of Chancery's open cynicism about plaintiffs-lawyers' conduct in representative actions"). In so arguing, however, Professor Stevelman offers nothing specific about why a derivative plaintiff's forum preference ought to be entitled to any weight at all, as against the preference of other plaintiffs, other investors, or the corporation's fiduciaries.
} 
of such counsel and still question why they or any one of their clients should be able to presumptively dictate where litigation on behalf of the corporation should proceed. This is especially true in the context of multi-forum litigation, in which other plaintiffs and other plaintiffs' counsel have a more or less equal claim of deference to their own different choice of forum. It is true in any event, given that the corporate representative plaintiff acts not solely for his own interests, but as a self-selected, unelected fiduciary for the corporation and all of its shareholders. ${ }^{239}$ That self-selection, moreover, is not without the potential for creating perverse incentives, as illustrated above: in an increasingly competitive environment, the ability of a plaintiffs' law firm to "plant a flag" in a distinct forum affords that firm a degree of leverage in negotiating fee-sharing, regardless of whether initiating such litigation is beneficial to the corporation, its shareholders, or society as a whole.

Thus, we claim that in representative litigation where the corporation's investors are geographically dispersed, the choice by any particular shareholder plaintiff to bring suit in her place of residence-let alone in some forum in which she does not even reside—ought not to be given any substantial deference. The importance of the forum choice to all investors, wherever located, counsels against giving undue, let alone presumptive, weight to the forum choice made by any one representative plaintiff, even one who resides in the forum state. The traditional approach of deferring to such a forum choice has never been justified, as a policy matter, in relation to representative

\footnotetext{
${ }^{239}$ E.g., Cohen v. Benefit Indus. Loan Corp., 337 U.S. 541, 549 (1949) (“a stockholder who brings suit on a cause of action derived from the corporation assumes a position, not technically as a trustee perhaps, but one of a fiduciary character. He sues, not for himself alone, but as representative of a class comprising all who are similarly situated.”); In re M\&F Worldwide Corp. S’holders Litig., 799 A.2d 1164, 1174 n.34 (Del. Ch. 2002) ("[B]y asserting a representative role on behalf of a proposed class, representative plaintiffs and their counsel voluntarily accept a fiduciary obligation towards members of the putative class.”).
} 
shareholder litigation, nor has any explanation been offered, to our knowledge, as to how or why such a forum choice ought to have greater significance than concerns relating to the full range of geographically dispersed investors and to judicial administration, and most notably the value of channeling litigation to the state most capable of developing the law through its judicial decisions.

As discussed above, the first-filed rule's original purpose was to serve as a tool for preventing "reactive" litigation. ${ }^{240}$ We acknowledge the potential for parties to file subsequent actions in another forum once they realize that the first filed action is not going in their favor, and we agree that the law should prevent parties from making such an end run around a plaintiff's choice of forum. ${ }^{241}$ But the analysis should examine the evidence that a party has initiated subsequent litigation opportunistically and not rely solely upon a mechanical timing assessment to determine whether to stay or dismiss the second filed case.

Mechanical application of the first-filed rule is especially troubling where the actions are contemporaneously filed. First of all, determining which action was filed first in those situations often requires detailed, almost comical, parsing of when filings and services of process are made. Secondly, where parallel actions are filed contemporaneously, reactive litigation's primary evil is not present: where the first-filed case has not progressed further than the second in any material sense, there is no meaningful prejudice to the first-filing party. Of course, allowing a technically secondfiled complaint to proceed would mean that the first-filing party would not enjoy its choice of forum. But for the reasons discussed above, there is no reason to give

\footnotetext{
${ }^{240}$ See supra notes 170 through 172 and accompanying text.

${ }^{241}$ See supra note 184 (citing opinions staying litigation that is commenced after plaintiff's claim suffers setbacks in prior-filed litigation).
} 
independent weight to the plaintiff's choice of forum in parallel shareholder representative actions. ${ }^{242}$ Thus, we propose that the deference to the plaintiff's choice of forum, as expressed in the Restatement ${ }^{243}$ and the cases that follow it, should be eliminated in cases where the plaintiff seeks to litigate on behalf of others.

It has been argued that mechanical application of the first-filed rule "promotes the positive goals of predictability and objectivity” and that “[p]redictability benefits litigants; objectivity benefits the legal system.”244 This argument is followed by the observation that "rejection of filing chronology to decide forum seems inefficient. It therefore looks especially bad for Delaware because Delaware's jurisprudence has championed the importance of clear, predictable rules of decision." ${ }^{245}$ Not surprisingly, we take a very different view of the matter. This argument fails to address the distinct considerations raised by using the first-filed doctrine in the representative litigation context. As a result, the argument does not take into account the costs of any mechanical predictability that might arise from a strictly enforced first-filed rule. We have two particular costs in mind. First, a blindly applied first-filed rule fails to acknowledge the costs, which we outline above, of directing litigation to a forum that is less equipped by experience and specialization to apply and develop governing law in a consistent manner.

Second, a mechanistically applied first-filed rule rewards conduct that no rational investor represented in a class or derivative suit would be expected ex ante to view as beneficial. "[P]leadings matter tremendously,”246 and a forum-selection rule that

\footnotetext{
${ }^{242}$ See supra notes 221-232 and related text.

${ }^{243}$ RESTATEMENT (SECOND) OF CONFLICT OF LAWs $\S 84 \mathrm{cmt}$. c (1971) ("[S]ince it is for the plaintiff to choose the place of suit, his choice of a forum should not be disturbed except for weighty reasons.").

${ }^{244}$ Stevelman, supra note 173 , at 110.

${ }^{245} \mathrm{Id}$.

${ }^{246} \mathrm{Id}$. at 112 .
} 
powerfully encourages the filing of poorly researched pleadings disserves represented investors and burdens courts with unnecessary motion practice. We agree that the choice of forum should not be dictated solely by which plaintiffs' lawyer has drafted the better complaint, ${ }^{247}$ but we are not advocating that approach at all; we are instead advocating that a reflexive, mechanistic reliance on filing chronology, in the name of predictability, objectivity or tradition, creates harmful incentives and should not be perpetuated.

2. Revise The Restatement's Forum Non Conveniens Factors to Give More Weight to Parties' Choice of Law Decisions

Our second recommendation is to reprioritize the factors in forum non conveniens analysis. As discussed above, under the Restatement and the law of most jurisdictions, forum non conveniens analysis requires the court to equally weigh a number of public and private interests. Key private interests include access to sources of proof, availability of compulsory process, the cost of obtaining attendance of unwilling witnesses, the possibility to view the premises (if appropriate to the action), etc. ${ }^{248}$ Public interests include the state's interest in keeping dockets from becoming overburdened, the obligation of jury duty being borne by the affected community, and the state's interest in avoiding having to interpret foreign law. ${ }^{249}$ As noted above, this is a flexible discretionary analysis that provides courts a great deal of leeway in deciding whether or not to exercise jurisdiction.

Although a state's interest in interpreting its own laws is a commonly enumerated factor in the foreign non conveniens analysis, it is only one consideration among several equally-weighted concerns. We propose changing that relationship in representative

\footnotetext{
${ }^{247} I d$.

${ }^{248}$ ReStATEMENT (SECOND) OF CONFLICT OF LAWS $\S 84 \mathrm{cmt}$. c (1971).

${ }^{249} \mathrm{Id}$.
} 
shareholder actions that are contemporaneously filed in multiple jurisdictions. In that situation, rather than simply being one among many factors of equal weight, the litigants’ choice of law should be accorded primary, presumptive significance when determining which forum is appropriate. In other words, all other considerations being equal—and they are not, because several of the geographically-centered factors have become largely obsolete in light of technological advances ${ }^{250}$ — we believe that the parties' choice of law decision should be the presumptively deciding factor in the forum non conveniens analysis. In the contract dispute context, this means that the parties' express choice of law as evidenced in the relevant agreement will presumptively determine which of multiple forums should handle the case; in the internal corporate affairs context, the courts of the state in which the defendant corporation is incorporated will presumptively handle the case.

\footnotetext{
${ }^{250}$ The traditionally cited forum non conveniens factors are surely no longer of equal significance, if they ever were. As has been previously pointed out, the importance of factors such as "relative ease of access to sources of proof" is substantially diminished today in comparison to the situation in 1947 when the Supreme Court announced the basic contours of the doctrine. Martin Davies, Time to Change the Federal Forum Non Conveniens Analysis, 77 TUL. L. REV. 309, 312, 324 (2002) (describing the Gilbert factors as "anachronistic," and urging that "most of the Gilbert factors should be given very different weight today than when they were first enunciated in 1947," and that "[e]ven if the factors are to remain unchanged, their application should now be very different because of recent changes in technology ....”). Professor Davies concentrates on application of the forum non conveniens doctrine in transnational litigation, because of his view that this doctrine "is now used only in international cases, where the alternative forum favored by the defendant is in another country." Id. at 312. Nevertheless, many of the points he makes translate well to application of the doctrine to litigation in multiple state forums. By way of most notable example, it seems downright naïve to give any significant weight to the physical location of documents, given that the "best evidence" rule (requiring presentation of original documents) has been largely eliminated, and documents can now be scanned, emailed, and printed (if necessary) to any significant commercial center in the world in a matter of seconds. Id. at 336-337 (noting the 1974, post-Gilbert revision of the Federal Rules of Evidence to eliminate the "best evidence" rule for most purposes); see also F.R.E. § 1003 ("A duplicate is admissible to the same extent as the original unless a genuine question is raised about the original's authenticity or the circumstances make it unfair to admit the duplicate.") Similarly, consideration of the potential need for a "view of the premises" is hardly the factor it once may have been, in light of the availability of video recording or direct video feeds. Id. at 345 .
} 
Operationalizing our recommended adjustment to the doctrine of forum non conveniens is simple, at least in terms of articulating a general test. ${ }^{251}$ The Restatement, after discussing the various private and public interests to be taken into consideration in the forum non conveniens analysis, describes the relationship between those factors as follows: "These two categories of factors are not mutually exclusive but rather supplement each other. Some differences, however, do exist among the courts of the various states as to whether one or the other of these two categories should be given primary emphasis." 252 At the end of that two-sentence summary, we propose adding the following guidance: "Unless other factors are compelling, however, primary weight in contemporaneously filed corporate or commercial contract actions should be given to the parties' choice of law, which not only reflects expressly the litigants' private interests but also invokes the chosen state’s public interest in developing its own jurisprudence.” In any event, we recommend that jurisdictions adopt corresponding language into their respective forum non conveniens doctrines.

This change is consistent with the Restatement's own public policy in resolving choice of law conflicts. When there is a bona fide question of what law applies to a dispute, the Restatement answers that in favor of the state with the most important and policy interests at stake. ${ }^{253}$ Our reasoning is analogous. When there is a forum dispute in a case where the parties' relations are governed by a particular state's corporate law,

\footnotetext{
${ }^{251}$ We have no serious expectation, of course, that the American Law Institute will any time soon revise the Restatement of Conflict of Laws. See Thomas \& Thompson, supra note 2, at *78 ("[I]t seems unlikely to us that the existing law reform organizations would be able to quickly and universally address the multijurisdictional litigation issues discussed in this paper.”). On the hand, it is hoped that individual courts and judges may find our suggestions informative and perhaps even persuasive in evaluating competing jurisdictional claims.

${ }^{252} I d$.

${ }^{253}$ See, e.g., RESTATEMENT (SECOND) OF CONFLICT OF LAWS §§ 6, 145, 188 (1971) (using the most significant relationship test to determine what law should apply).
} 
directing that dispute to be resolved by that state's courts is in line with directing the case to be resolved by the courts with the supreme policy interest.

\section{Reinvigorate the Restatement's Respect for Internal Affairs Doctrine}

We also suggest a related change to the Restatement's treatment of jurisdiction over cases involving the internal affairs of a foreign corporation. The Restatement (Second) of Conflict of Laws states that "[a] court will exercise jurisdiction over an action involving the affairs of a foreign corporation unless it is an inappropriate or an inconvenient forum for the trial of the action" 254 and provides in its comments a number of considerations, ranked in order of importance, for determining whether to dismiss a suit over the internal affairs of a corporation, including: (1) whether the court has the ability to grant effective relief; (2) the nature of the foreign corporation's relationship to the state of the forum, and the issue involved in the suit; and (3) those factors typically considered in the forum non conveniens analysis discussed above. ${ }^{255}$ The Restatement places an analysis of the corporation's contacts with a forum at the heart of the question of whether to hear a case involving the internal affairs of a corporation:

[W]hen the corporation is only technically a foreign corporation, since all, or the great majority, of its contacts, other than the place of its incorporation, are in the state of the forum, the courts will even entertain actions which call for relief affecting the corporation's organic structure or internal administration. So, when the business of a foreign corporation is carried on entirely or principally in the state of the forum and when the directors of the corporation or a majority of them reside in the state and are accustomed to hold meetings in the state, the court may entertain an action which questions the validity of a stock issue or of a dividend or which seeks to enjoin a proposed reorganization of the corporation or to require the calling of a shareholders' meeting. ${ }^{256}$

\footnotetext{
${ }^{254} I d . \S 313$.

${ }^{255}$ Id. cmt. c.

${ }^{256} \mathrm{Id}$.
} 
In other words, the Restatement suggests an analysis akin to the minimum contacts analysis undertaken to determine whether personal jurisdiction is appropriate in the first place. ${ }^{257}$ The Restatement takes the minimum contacts paradigm so far, and neglects shareholders' legitimate interest in incorporating in a certain jurisdiction on account of the characteristics of its corporate law, that it refers to some corporations as only "technically" incorporated in a jurisdiction while they are de facto creatures of another jurisdiction. ${ }^{258}$

Rather than repeating an analysis of the minimum contacts factors, we recommend changing this language to reflect the fact that the shareholders' choice to incorporate in a particular state is an indication of which forum has the most important policy interest. As previously noted, the Restatement acknowledges that the parties' choice of law is important:

Indeed, the suit may be dismissed even in a situation where the court, if it were to hear the case, would apply the local law of the state of incorporation in reaching its decision. This is because uniformity of result, as well as the giving of proper attention to local custom that is not reflected in law books, can best be assured by having the action tried in the state of incorporation. ${ }^{259}$

But the Restatement subsumes the interest of the state and the markets in maintaining doctrinal uniformity within the broader framework of the minimum contacts analysis. We propose elevating that explicit concern for consistency from its current role as an ancillary consideration to the leading factor for determining which forum has the dominant interest in adjudicating a dispute.

\footnotetext{
${ }^{257} I d$

${ }^{258} \mathrm{Id}$.

${ }^{259} \mathrm{Id}$.
} 
Namely, we recommend changing $\S 313$ by qualifying its basic premise ("A court will exercise jurisdiction over an action involving the internal affairs of a foreign corporation unless it is an inappropriate or an inconvenient forum for the trial of the action.”). Although we do not quarrel with that principle where there is no prospect of parallel contemporaneous litigation in the courts of the state of incorporation, we submit that it is important to qualify that principle by elaborating that "A court will ordinarily not exercise jurisdiction over an action involving the internal affairs of a foreign corporation where there is a contemporaneously filed parallel action in the forum of incorporation.” We would then revise lengthy Comment c in Section 313 to reflect the position that (1) the shareholders' choice to incorporate in a given state is an expression of their presumptive preference as to where suits involving the internal affairs of the corporation should be heard, and that (2) absent certain circumstances, and in the situation where there are contemporaneously filed actions in the state of incorporation as well as in one or more other states, the state of incorporation is presumed to have the greater policy interest in adjudicating such disputes. ${ }^{260}$

Our proposal is consistent with the Restatement's own de-emphasis of geography as to causes of action where geographical residence has less relationship to the parties' legitimate expectations and the parties have chosen the law to govern their

\footnotetext{
${ }^{260}$ We would also suggest parallel changes to $\S 84 \mathrm{cmt}$. d, which briefly discusses the internal affairs doctrine and refers to $\S 313$. We would also amend Comment e of § 145 ("Torts-The General Principle"), which states that "[a]t least with respect to most issues, a corporation's principal place of business is a more important contact than the place of incorporation, and this is particularly true in situations where the corporation does little, or no, business in the latter place." We would clarify that these "most issues" cover torts, but not the internal governance of a corporation. Indeed, Comment $\mathrm{f}$ of $\S 145$ gives less weight to geographic considerations in the case of torts where "the place of injury is less significant," such as unfair competition.
} 
relationship. ${ }^{261}$ As to internal affairs cases involving a corporation with stockholders of diverse residence, the only logical geographic consideration, if it be so considered, is the state of incorporation because that is the geographic unit on which the relevant expectations focus. In such a case, the location of the corporation's headquarters, or its largest facilities, or employee bodies, has no relationship to the cause of actions or the stockholders' expectations of the persons - the stockholders-whose interests are to be determined in the litigation. ${ }^{262}$ Rather, our proposal comports with the Restatement's own emphasis on ensuring predictability and uniformity of result, which are “of particular importance in areas where the parties are likely to give advance thought to the legal consequences of their transactions.”263

It is important to note that our prescription is not meant to be a wholesale return to the application of the internal affairs doctrine as a jurisdictional bar. ${ }^{264}$ Rather, we are proposing a measured shift of the burden in determining which forum has the greater interest in deciding a case. As it currently stands, the forum non conveniens doctrine is an open-ended analysis, emptied of most practical content by the fact that it parrots the factors examined in the minimum contacts analysis for determining personal jurisdiction without any convincing determination of why those factors bear on which forum should decide a corporate law case. Our recommendations reinvigorate the rule by increasing the burden on the plaintiffs to show why it is important for a court in the non-

\footnotetext{
${ }^{261}$ See, e.g., id. § $6 \mathrm{cmt}$. c (noting, for example, that the law of the situs should be given most weight in land transactions, but that "the policies in favor of protecting the basic expectations of the parties and of effectuating the basic policy underlying the particular field of law come to the fore in the rule that, subject to certain limitations, the parties can choose the law to govern their contract”);

${ }^{262}$ The Restatement recognizes this logic. See id. § 47 ("Foreign Corporations-Doing Business In State"), at (1) ("A state has power to exercise judicial jurisdiction over a foreign corporation which does business in the state with respect to causes of action arising from the business done in the state.") (emphasis added).

${ }^{263}$ Id. cmt. i.

${ }^{264}$ See supra Subsection II.A.3.
} 
incorporating state to hear the suit, while nevertheless maintaining the option for courts to decide cases involving the affairs of foreign corporations in exceptional circumstances.

\section{The Limits of Our Recommended Doctrinal Changes}

Before concluding, we wish to dispel any overly aggressive reading of our recommendations for doctrinal reform. Most importantly, we do not advocate an inflexible insistence that in the case of competing forums, a class or derivative suit involving corporate internal affairs must invariably proceed in the courts of the state of incorporation. For example, when the governing legal principles are thoroughly settled and the facts do not present novel issues, and the defendants, plaintiffs, and the court in a jurisdiction other than the state of incorporation have actively and responsibly advanced the proceedings, a belatedly filed complaint in the state of incorporation should not compel the court there to go forward with the case simply because the law of its state is at issue. ${ }^{265}$ Thus, productive progress in litigation—as distinguished from mere chronological priority of filing—can militate in favor of centering litigation in courts other than those of the state of incorporation, and our recommended presumptive preference for litigation in those courts can give way to considerations of efficient allocation of judicial and litigants' resources. Likewise, where claims involving the corporation's internal affairs are factually intertwined with more substantial claims governed by the law of a jurisdiction other than that of the state of incorporation, it could be more efficient overall to have all claims resolved by one court, even if that court were

\footnotetext{
${ }^{265}$ See, e.g., Teachers’ Ret. Sys. v. Scrushy, 2004 WL 423122 (Del. Ch. Mar. 2, 2004) (staying a derivative action in favor of derivative litigation filed in Alabama, where the Delaware action-and even the books and records litigation that preceded it—was commenced after substantial progress in the Alabama proceedings, including orders coordinating plaintiffs' counsel, and where the existence of personal jurisdiction in Delaware over certain officer defendants in the Alabama proceedings was doubtful).
} 
not situated in the state of incorporation. ${ }^{266}$ This same result may be appropriate where the corporate law claims are factually intertwined with pending claims subject to exclusive federal jurisdiction, such as claims arising under the Securities Exchange Act of $1934 .^{267}$

\section{Conclusions}

The impetus for this article is the recent growth in parallel class and derivative litigation challenging corporate action. The large percentage of such cases that are resolved by settlement in which the only monetary compensation flows to plaintiffs' counsel, and neither the corporation nor the class of stockholders receives any such consideration, invites closer examination of the situation to determine whether such parallel litigation is promoting undue agency costs. We have suggested a variety of specific ways in which such costs come about, all of which are exacerbated by uncertainty over the forum in which the litigation will ultimately proceed.

We propose that such uncertainty may be mitigated by measured reformulation of the judicial doctrines—-forum non conveniens and the first-filed rule—-that have been developed to sort out the choice among competing venues for parallel litigation. We find that such doctrines, as applied to interstate venue conflicts, were developed largely to limit reactive litigation by a defendant in a first-filed suit, and are not well tailored to address competing class or derivative actions brought by multiple putative shareholder

\footnotetext{
${ }^{266}$ See Brookstone Partners Acquisition XVI, LLC v. Tanus, C.A. No. 7533-VCN (Del. Ch. Nov. 20, 2012) (dismissing on forum non conveniens grounds in favor of previously filed litigation in Texas, in part because the facts giving rise to claims under an LLC agreement of a Delaware LLC also involved claims of breach of an employment agreement governed by Texas law); IM2 Merchandising \& Mfg. v. Tirex, 2000 WL 1664168, at *10 (Del. Ch. Nov. 2, 2000) (dismissing on forum non conveniens grounds in part because a claim of arising under Delaware law involved "at best a min[u]scule part of this case").

${ }^{267} 15$ USC § 78aa. In such situations, the federal court is guided by the prudential considerations articulated in Colorado River and described supra note 160.
} 
representatives. In particular, we claim that such doctrines, as applied in the field of parallel shareholder representative litigation, do not adequately capture the importance of the choice of law — that of the state of incorporation—made by investors in the corporation. In particular, we claim that the relevant doctrines need to give effect to the systemic value of consistent development of governing precedent and of consistent judicial oversight of the corporate representative litigation system itself.

Accordingly, we propose several related doctrinal refinements. First, in applying the doctrine of forum non conveniens, the parties' choice of law should be given presumptive weight; in other words, shareholder representative litigation should presumptively go forward in the jurisdiction that supplies the governing law, unless the traditional forum non conveniens considerations of public and private interests demonstrate otherwise. Second, chronological priority of filing of representative shareholder lawsuits should be deemed irrelevant, in and of itself, where such suits are filed contemporaneously. In that circumstance, an unelected, representative plaintiff's choice of forum merits no sensible deference. Finally, we propose that the internal affairs doctrine be strengthened in a related way, such that where there are contemporaneously filed actions in the state of incorporation as well as in one or more other states, the state of incorporation is presumed to have the greater policy interest in adjudicating such disputes. 